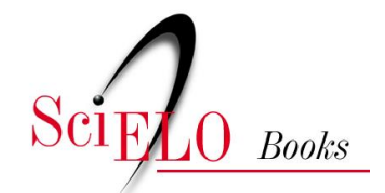

\title{
As raças humanas e a responsabilidade penal no Brasil
}

\author{
Raymundo Nina Rodrigues
}

\section{SciELO Books / SciELO Livros / SciELO Libros}

RODRIGUES, RN. As raças humanas e a responsabilidade penal no Brasil [online]. Rio de Janeiro: Centro Edelstein de Pesquisa Social, 2011, 95p. ISBN 978-85-7982-075-5. Available from SciELO Books $<$ http://books.scielo.org $>$.

\section{(1) (1)(2)}

All the contents of this chapter, except where otherwise noted, is licensed under a Creative Commons Attribution-Non Commercial-ShareAlike 3.0 Unported.

Todo o conteúdo deste capítulo, exceto quando houver ressalva, é publicado sob a licença Creative Commons Atribuição Uso Não Comercial - Partilha nos Mesmos Termos 3.0 Não adaptada.

Todo el contenido de este capítulo, excepto donde se indique lo contrario, está bajo licencia de la licencia Creative Commons Reconocimento-NoComercial-CompartirIgual 3.0 Unported. 


\section{BIBLIOTECA VIRTUAL DE CIÊNCIAS HUMANAS}

\section{As RAÇAS HuMANAS \\ E A RESPONSABILIDADE PENAL No BRASIL}

\section{Raymundo Nina Rodrigues}




\section{As raças humanas e a responsabilidade penal no Brasil}

Esta publicação é parte da Biblioteca Virtual de Ciências Humanas do Centro Edelstein de Pesquisas Sociais - www.bvce.org

O objetivo do projeto é colocar na Internet, para acesso gratuito, livros já publicados, de autores brasileiros ou residentes no Brasil, em português ou outras línguas, de todas as disciplinas das ciências humanas. Os livros que integram o site se encontram esgotados e os direitos autorais retornaram aos autores, ou seus direitos autorais ainda se encontram em mãos das editoras, mas estas autorizaram a colocação no site. Também podem ser encontrados no site livros que já estejam em domínio público, respeitada a autoria. Este projeto é uma iniciativa do Centro Edelstein de Pesquisas Sociais em parceria com as diversas associações acadêmicas.

A inclusão dos livros no portal foi feita com a devida autorização dos autores ou herdeiros dos direitos autorais. Contudo, caso algum livro incluído esteja violando direitos de edição, por favor, entre em contato conosco para que possamos regularizar a situação.

Domínio Público. Nenhuma parte desta publicação pode ser reproduzida ou transmitida por qualquer meio de comunicação sem a indicação de autoria.

ISBN 978-85-7982-075-5

Centro Edelstein de Pesquisas Sociais

www.centroedelstein.org.br

Rua Visconde de Pirajá, 330/1205

Ipanema - Rio de Janeiro - RJ

CEP: 22410-000. Brasil

Contato: bvce@centroedelstein.org.br 


\section{SUMÁRIO}

Introdução II

\section{Capítulo I}

Criminalidade e a imputabilidade à luz da evolução social e mental

\section{Capítulo II}

O livre arbítrio relativo nos criminalistas brasileiros

\section{Capítulo III}

As raças humanas nos códigos penais brasileiros

\section{Capítulo IV}

O Brasil antropológico e étnico

\section{Capítulo V}

A população brasileira no ponto de vista da psicologia criminal - Índios e negros

\section{Capítulo VI}

A população brasileira no ponto de vista da psicologia criminal - Os mestiços

\section{Capítulo VII}

A defesa social no Brasil

\section{INTRODUÇ̃̃o}

Não tive a mente de abrir discussão neste trabalho sobre as doutrinas, sobre os princípios científicos que o inspiraram. Tais quais os aceito, apliqueios à solução de um problema médico-legal. Mérito ou demérito, só pode haver aqui, portanto, na legitimidade ou ilegitimidade das aplicações feitas e das conclusões tiradas. Para condenar a obra, de nenhum outro pretexto tem, pois, necessidade aqueles a quem motivos de crenças religiosas, ou de exagerado partidarismo de escola, tornaram inconciliáveis com essas doutrinas e porventura incompatíveis com um espírito de crítica, reto e imparcial.

Avesso por natureza às manifestações dessa intolerância irritadiça e mórbida que não pode sofrer a menor contradição, lamentarei que a forma de trabalhar a matéria venha a servir de pretexto para que não mereça as honras de uma discussão proveitosa uma tese a que se prendem problemas sociais múltiplos e importantes.

No entanto, este opúsculo não pode pretender mais do que ele realmente é: simples ensaio de psicologia criminal brasileira, destinado a ser profundamente retocado. De todos os seus defeitos, me limitarei a tentar a justificação do mais saliente, aliás, talvez o menos importante deles - o abuso e a extensão das citações -, pela necessidade de apoiar a contradita oferecida a doutrinas correntes e a opiniões de mestres justamente reputados as primeiras autoridades na matéria.

Por outro lado, posso confessar. Se muito me preocupou o fundo, pouco ou nada me mereceu a forma. Mesmo sem prévia audiência dos mestres, aportuguesei termos e locuções que em rigor poderiam ser expressos em mais puro vernáculo.

Que fazer? Pecador impenitente, contínuo a ser nota dissonante no concerto geral de cultura à forma que tanto preocupa, mesmo aqueles que, sem o saber, me fazem boa e honrosa companhia. Diga-se a verdade, os Franciscos de Castro são ainda a exceção entre nós.

Vem isto a propósito de explicar a preferência dada à forma de lições, para explanar o assunto. Certamente não tive, nem podia ter o intento de exibir eloquência, pureza ou elevação de estilo. 
O motivo único foi deixar significado por este modo que o estudo hoje publicado teve por objeto exclusivo o ensino da medicina legal na faculdade em que tenho a honra de ser professor.

Se ainda uma vez tiver de abandonar este novo ramo de especialização do magistério, ficarão os ensaios de hoje como testemunho da minha passagem por essa cadeira.

Se nela continuar, porém, tenho fé que hei de completai-os, imprimindo ao ensino da medicina legal nesta faculdade esse cunho fecundíssimo de aplicações praticas, cujo programa traçou magistralmente em seu importante relatório o atual proprietário da cátedra.

Todos os meus esforços neste sentido terão ainda outro alcance que não é para mim menos capital, o de tranquilizar aqueles bons amigos que sempre me fizeram a honra de não descrer da minha dedicação aos cargos com que me distinguem.

Bahia, Julho de 1894. Nina Rodrigues

\section{CAPÍTULO I}

\section{CRIMINALIDADE E A IMPUTABILIDADE À LUZ DA EVOLUÇÃO SOCIAL E MENTAL}

Sumário - O desenvolvimento mental no gênero humano; tempo e sucessão que requer. Gênese do senso moral, das ideias de justiça e de direito; Relatividade do conceito de crime; condições de sua uniformidade em um povo ou raça. A evolução mental em contradição com o livre arbítrio. Conclusões.

Constituirá objeto destas próximas conferências, o estudo das modificações que as condições de raça imprimem à responsabilidade penal.

Terei iniciado assim o exame das causas que podem modificar a imputabilidade e que, em uma classificação só aceitável a benefício de inventário, foram distribuídas pelo professor Zino em quatro grupos distintos: o dos modificadores mistos da imputabilidade.

I. A concepção espiritualista de uma alma da mesma natureza em todos os povos, tendo como consequência uma inteligência da mesma capacidade em todas as raças, apenas variável no grau de cultura e passível, portanto, de atingir mesmo num representante das raças inferiores, o elevado grau a que chegaram as raças superiores, é uma concepção irremissivelmente condenada em face dos conhecimentos científicos modernos.

Não são tão simples e contingentes as causas do pé de desigualdade em que se apresentam na superfície do globo as diversas raças ou espécies humanas, que disputam a sua posse.

Ao contrário, elas reproduzem no espaço, com mais ou menos fidelidade, os estágios ou fases, porque no tempo e sob a pressão de causas inexoráveis e poderosas, passou o aperfeiçoamento evolutivo daqueles grupos antropológicos que conseguiram triunfar pela adaptação e ocupar a vanguarda da evolução social. 
Também, suprindo a insuficiência do exame subjetivo, tão caro à metafísica espiritualista, a análise objetiva dos fenômenos físicos, iluminada pelos princípios da evolução biológica, veio demonstrar que a inteligência humana tira as suas raízes genealógicas, muito longe e bem em baixo, do automatismo reflexo dos animais inferiores.

$\mathrm{O}$ aperfeiçoamento lento e gradual da atividade física, inteligência e moral não reconhece, de fato, outra condição além do aperfeiçoamento evolutivo da série animal.

Simples funções orgânicas pressupõem e têm elas o seu substrato material e anatômico no gradual aperfeiçoamento e crescente complicação de textura de um sistema orgânico, o sistema nervoso

Mas na série animal as complicações crescentes na composição histológica ou bioquímica da massa cerebral só se operam com o auxílio da adaptação e da hereditariedade, de um modo muito lento e no decurso de muitas gerações. Assim também, os graus sucessivos do desenvolvimento mental dos povos.

Não só, portanto, a evolução mental pressupõe nas diversas fases do desenvolvimento de uma raça, uma capacidade cultural muito diferente, embora de perfectibilidade crescente, mas ainda afirma a impossibilidade de oprimir a intervenção do tempo nas suas adaptações e a impossibilidade, portanto, de impor-se, de momento, a um povo, uma civilização incompatível com o grau do seu desenvolvimento intelectual.

É um dogma em biologia, escreveu o Dr. Anselmo da Fonseca (Memória Histórica da Faculdade da Bahia, 1892) que, ainda que todos os seres vivos - animais e vegetais - possam se adaptar às condições mais diversas e que, ainda que o homem, particularmente o mais civilizado, seja de todos eles o mais adaptável e o mais perfectível, essas adaptações não se fazem, não se podem fazer senão pouco a pouco, gradativamente e com grande lentidão. A História mostra que este princípio é igualmente verdadeiro no domínio social e que ele se entende com os meios intelectuais e morais, ou superorgânicos, do mesmo modo que com os físicos como o clima... Todavia tem-se pretendido, não obstante o Natura non facit saltus de Linneo, fazer um povo selvagem, ou bárbaro transpor, no curso da vida de uma geração, o caminho percorrido pelas nações civilizadas durante séculos, como se fosse possível suprimir a lei da herança, dispensar as lentas acumulações hereditárias e prescindir da ação necessária do tempo. Houve até quem pretendesse civilizar os algerianos, fazendo-os conhecer os direitos do homem e do cidadão, cuja declaração chegou a ser lida pública e somente às massas, que sem dúvida nada perceberam, além das pompas do espetáculo.

São de outra ordem - e sempre incapazes de invalidar estes princípios os casos de conversão moral em uma só geração, de que fala tarde. Com inteira aplicação a esta tese escreveu o Dr. Letourneau (Sociologie):

Para crer que em um tour de main e recorrendo à força, se pode transformar a moralidade de um povo, é preciso ser missionário. $\mathrm{O}$ estado mental de uma raça, seus apetites, suas tendências resumem a vida mesma dessa raça, a série das impressões cerebrais, dos feitos e façanhas de uma cadeia inteira de geração, e para apagar o traço dos séculos, é indispensável uma longa educação, cujo efeito se transmita de pais a filhos.

Ensinado pela experiência das catequeses, nenhum povo mais do que o brasileiro pode dar testemunho das grandes verdades contidas nestes conceitos.

O que é feito hoje das civilizações bárbaras brilhantes, complexas e poderosas que, ao tempo da descoberta da América, ocupavam o México e o Peru?

Dissolveram-se, desapareceram totalmente na concorrência social com a civilização europeia, muito mais polida e adiantada.

Onde estão as colônias prósperas e civilizadas dos selvagens brasileiros que a abnegação sincera e convencida dos nossos missionários se gloriava, em santa ingenuidade, de haver conquistado para o rebanho do Senhor?

A verdade é que o selvagem americano erra ainda hoje nos centros desertos das nossas florestas virgens, sempre refratário e sempre a fugir da civilização europeia, que de todos os lados o assedia e aperta, preparando ao mesmo tempo a sua próxima extinção total. A verdade é que apenas pela mestiçagem se pode ele incorporar à nossa população, incapaz como estava socialmente, de receber e adotar por si a civilização europeia importada com os colonizadores.

Ninguém irá acreditar agora que o insucesso tremendo dessa campanha gigantesca de civilização e conversão, sustentada por homens de levantados intuitos e de cada um dos quais a fé, a convicção religiosa, que 
os animava, fazia um herói, tivesse sido ocasionada apenas por erros e defeitos de orientação e modo de conduzi-la.

As concepções errôneas da psicologia espiritualista haviam, de fato, preparado, em suas falsas promessas, o insucesso de tão infundadas esperanças.

A causa foi, pois, positiva e material - a necessidade de tempo e a incapacidade orgânica dos aborígenes para a adaptação social que se exigia deles.

Se a natureza moral de um povo, escreveu dos indígenas brasileiros um homem profundamente convencido de sua educabilidade (Couto de Magalhães, O Selvagem, p. 191), fosse como uma tira de papel, onde se escreve quanto nos vem à cabeça, então seria tão fácil mudar-lhes os costumes como é fácil escrever. Feliz ou infelizmente não é assim. Esses costumes rudes são mais tenazes do que os de um povo civilizado; entrelaçam-se com seus sentimentos, suas necessidades e até suas crenças e superstições religiosas. O mais rudimentar conhecimento da natureza faz ver que é impossível alterar essas coisas sem o decurso de algumas gerações e por outro meio que não seja a educação do menino, especial e dirigida para esse fim e com vistas de reduzi-lo a intérprete que sirva de laço entre o índio e o cristão.

O estudo das raças inferiores tem fornecido à ciência exemplos bem observados dessa incapacidade orgânica, cerebral.

A resistência oposta por ela é quase invencível, mantendo-se latente mesmo naqueles casos em que o sucesso pareceu mais completo.

Às vezes, diz o Dr. Letoumeau (Sociologie), nos polinesianos educados à europeia, o instinto selvagem, a tenaz influência ancestral acabam por predominar e, uma vez chegado à idade adulta, o neófito, para voltar aos bosques, sacode, mau grado seu, o jugo da civilização estrangeira. Marsden observou um fato destes na Nova Zelândia em um taitiano, educado nas escolas de Port-Jackson, para onde tinha sido levado na idade de onze anos.

Qualquer que seja a reserva com que tenhamos de aceitar narrações desta natureza, pois vemos o Dr. Letourneau afirmar, sob a informação de Peschel, o caso inexato de um botocudo doutorado em medicina por esta faculdade, e que, num momento dado, abandonou tudo para voltar às selvas, sempre é indiscutível que nelas se contém muita verdade.
Conhece-se bem no Brasil quanto é forte a influência ancestral nos indígenas e a facilidade com que os já reputados civilizados voltam à vida de selvagem. Pessoalmente conheço fatos desta espécie, ocorridos no Estado do Maranhão, onde a cargo de pessoa de minha família está a direção de uma das colônias dos indígenas soi-disant civilizados.

Mas todos estes fatos são apenas documentos comprobatórios das leis gerais do desenvolvimento mental no seu mecanismo filogenético.

Constituem os princípios básicos e fundamentais da psicologia moderna, que o másculo esforço da escola inglesa destacou da biologia contista e concedeu foros de ciência distinta.

Cultivada e considerada hoje condição imprescindível de toda boa instrução fundamental, eles devem ser do domínio comum e não requerem, por isso, especial e maior desenvolvimento para as aplicações que passo a fazer.

II. Aplicado à gênese das ideias do bem e do mal, do justo e do injusto, do direito e do dever - base da moral e suposto fundamento do direito de punir na escola criminalista clássica -, o método comparativo, que vimos operar tão grande revolução na psicologia, demonstra que, longe de uma procedência sobrenatural ou suprassensível, essas ideias não são mais do que o resultado ideal da elaboração psíquica por que passou o sentimento instintivo de defesa fatal e mesmo inconsciente nas suas manifestações reflexas precordiais.

A ineidade delas, verificada pela análise subjetiva nas raças superiores e que pareceu justificar a crença na sua proveniência extranatural, se explica ao contrário muito naturalmente pela procedência hereditária, legado que foi de muitos séculos de repetição e aperfeiçoamento, o que acabou por identificá-las e torná-las inerentes ao aperfeiçoamento psíquico da humanidade.

Todavia, nos domínios das legislações penais reinam ainda como princípios soberanos os velhos conceitos metafísicos da filosofia espiritualista.

Escolhida dentre muitos outros exemplos que fora descabido citar agora, a recente declaração de Frank, autor da Philosophie du droit penal, basta para nele demonstrar. 
Não quero tocar na lei penal escrita, diz ele na introdução da sua obra, senão para submeteu à verificação dessa lei eterna de que fala Cícero e que é a mesma em Atenas como em Roma e cujo texto não se acha em parte alguma a não ser na razão divina e na consciência do gênero humano.

Esta velha doutrina da ineidade e uniformidade das ideias do bem e do mal, do justo e do injusto em todos os cérebros humanos, quaisquer que sejam o país e a raça, observa Letourneau (L'évolution juridique, etc.), é ainda, como sabemos, ensinada oficialmente em toda a Europa; mas ela não se poderia manter um instante em face dos grandes fatos de observação, postos em evidencia pela antropologia, e para acreditá-la fundada, é preciso não ter em menor conta três quartas partes da humanidade.

Com efeito, a universalidade e a identidade dessas ideias e sentimentos são desmentidas de um modo formal pelo exame comparativo do critério de reprovação ou louvor, de criminalidade ou permissão, de punição ou de prêmio, que em uma época dada emprestaram os diversos povos a certos atos, ou que, para um mesmo povo, tiveram eles no decurso da sua evolução social.

Que as diversas famílias antropológicas mostram um modo diverso de compreender as ideias morais e jurídicas e tenham por isso uma delinquência especial, escreve Zino (Medicina Legale), é um fato que só pode contradizer aquele que, submisso a velhos prejuízos de escola, considera o crime como alguma coisa de imutável, de absurdo, uma ofensa à divindade, uma contravenção às leis eternas que o criador imprimiu na consciência humana. Para um observador atento e despido de prejuízos, o crime não é mais do que um conceito relativo, à semelhança do direito de que é a negação; resulta daí que o que é para nós ação delituosa pode não ser tal para outros povos da Terra; que ato merecedor de castigo em tempos idos pode bem ser tido hoje por digno de econômicos: nos elementos constitutivos dos crimes em particular. E à mim me parece tão evidente este princípio que não insisto em demonstrá-lo: dele terei de dar exemplos luminosos quando me ocupar do homicídio, do aborto, do infanticídio, dos atentados contra os bons costumes, etc.

Retenhamos, sobretudo, este fato, escrevia Tarde na Criminalitê Comparêe, que a gravidade proporcional dos diversos crimes muda consideravelmente de idade em idade. Na Idade Média, o maior dos crimes era o sacrilégio; depois vinham os atos de bestialidade ou de sodomia e bem longe em seguida o homicídio e o roubo. No Egito e na Grécia era o fato de deixar os pais sem sepultura. A preguiça, nas nossas sociedades laboriosas, tende a tornar-se o atentado mais grave, ao passo que outrora o trabalho era degradante. Talvez venha ainda um momento em que o crime capital, num globo excessivamente aglomerado, seja ter uma família numerosa, ao passo que outrora a vergonha era não ter filhos. Nenhum de nós pode se lisonjear de não ser um criminoso nato relativamente a um estado social dado, passado, futuro ou possível.

Passando de uma civilização a outra, ou percorrendo as fases sucessivas de uma mesma civilização, afirma ele na filosofia penal e vemos certos fatos cair da categoria dos grandes crimes na dos delitos menores e tornar-se por fim lícitos se não louváveis; por exemplo, da Idade Média até hoje, o livre pensamento religioso, a blasfêmia, a vagabundagem, o furto de caça, o contrabando, o adultério, a sodomia: ou o inverso, de lícitos, de louváveis que eram, passar a ligeiramente delituosos e depois a criminosos; por exemplo, da Antiguidade à Idade Média, o aborto, o infanticídio, a pederastia, a fornicação.

Este duplo movimento de transformação que consiste nas qualificações diferentes de um mesmo fato ora permitido, ora punido, se opera sob a ação da lógica inconsciente que preside a todas as transformações da sociedade e que tende a pôr de acordo as crenças com as necessidades, as crenças e as necessidades com os atos.

Não indagaremos, diz por sua vez Garofalo (La Criminalogie), se tudo o que é crime para o nosso tempo e a nossa sociedade teve sempre e por toda parte o mesmo cunho e vice-versa.

A questão seria quase pueril. Quem não se lembra de ter lido que nos costumes de muitos povos, o homicídio para vingar um homicídio não somente era tolerado, mas, que para os filhos da vítima constituía o mais sagrado dos deveres? Que o duelo tem sido ora punido com as penas mais severas, ora legalizado a ponto de constituir a principal das formas processuais? Que a heresia, a feitiçaria, o sacrilégio, que eram considerados outrora os crimes mais detestáveis, desapareceram atualmente de todos os códigos dos povos civilizados? Que a pilhagem de um navio estrangeiro naufragado era autorizada por lei em certos países? Que o salteamento e a pirataria constituíram durante séculos os meios de existência de povos hoje civilizados? Que finalmente, saindo da raça europeia, encontram-se antes de chegar aos selvagens, sociedades semicivilizadas que autorizam o infanticídio e a venda das crianças, que honram a prostituição e fizeram mesmo do adultério uma instituição? Estes fatos são muito conhecidos para que seja necessário insistir neles. 
Não tem outro fundamento senão o antagonismo entre a criminalidade atual e a dos homens primitivos, dos selvagens, a origem atávica do criminoso, sustentada nos primeiros trabalhos de Lombroso, e ainda hoje defendida em toda a sua pureza, entre outros, pelo distinto alienista francês, Sr. Morandon de Montyel.

Esta divergência, esta oposição no modo de apreciar a criminalidade nos diferentes povos, que julguei necessário comprovar com o testemunho acorde de todas as citações lidas, tem sido interpretada principalmente de dois modos distintos; porque também de dois modos distintos se tem compreendido nas raças humanas o desenvolvimento do senso moral, da infração de cujos ditames o crime é principalmente uma função.

Ou, os múltiplos fatores da evolução sociológica, que determinam a marcha progressiva da civilização dos povos, foram fazendo nascer gradualmente, nas suas fases sucessivas, sentimentos morais novos, que tiveram como consequência modificar paralelamente o modo de apreciar o caráter delituoso dos mesmos atos, de acordo com as exigências sociais das novas épocas ou civilizações.

$\mathrm{Ou}$, os mesmos sentimentos, brotados na alma humana em data muito remota da evolução filogenética, daí por diante não fizeram mais do que aperfeiçoar-se em extensão, dilatando-se a mais e mais, até abranger em seu seio como em uma só família, a humanidade inteira.

O segundo ponto de vista, que é o do professor Garofalo, pressupõe a existência de um critério fundamental da criminalidade, pelo menos do delito natural, na violação do senso moral médio, representado pelos dois sentimentos básicos da probidade e da piedade, existentes em todos os povos chegados a certa fase de desenvolvimento.

As diferenças, que a ciência constata, no tempo e no espaço, no modo de considerar os atos criminosos, ele as explica pelo sentido em que se dá o aperfeiçoamento social desses sentimentos básicos.

Gradualmente se vão tornando mais compreensivos, passando do clã familiar à tribo, desta à cidade, da cidade à pátria, e elevando-se finalmente da pátria à humanidade.

Desta sorte, o homicídio, por exemplo, que só era crime quando praticado num membro da própria tribo e ação permitida e até meritória quando recaía em membro de uma tribo estranha, mais tarde, quando o sentimento de piedade englobou todas as tribos numa só família, adquiriu em todos os casos a qualidade delituosa que só tinha naquela espécie particular.

Por este modo procura Garofalo responder à justa alegação de Aramburu de que a sua teoria importa uma contradição aos princípios da moral evolucionista.

Se, como parece, a doutrina desenvolvida brilhantemente pelo eminente criminalista italiano não encerra toda a verdade em matéria de evolução da moral, todavia é justo reconhecer que com ela deve estar boa parte do seu mecanismo filogenético.

É isto reconhece o próprio Tarde, que, aliás, se inclina para outra ordem de explicação causal.

Para os evolucionistas, a formação de uma ideia abstrata de justiça, tal como a possuímos hoje, se operou lentamente no cérebro humano por força do aperfeiçoamento social, extremamente moroso e demorado, da humanidade.

O movimento reflexo e instintivo de defesa individual transformou-se nos clãs familiares, por exigência dessa forma de organização social, no talião, que já era uma vingança disciplinada e racional. Desta, nasceu naturalmente a composição pecuniária como mais proveitosa aos outros membros da horda ou tribo.

Até então nada há nestes atos que possa lembrar a existência de uma ideia de justiça.

Mas as cerimônias processuais, mais ou menos rudimentares, daqueles primeiros atos jurídicos foram guardadas pela tradição e transmitidas às gerações que se seguiram. Com o correr dos tempos confundiram-se como as crenças religiosas, porque os padres, diz Letourneau, que se julgaram sempre depositários natos das tradições dos povos, delas se apoderaram.

Com esta atribuição a uma origem divina, começou a formar-se a ideia abstrata de uma justiça impessoal, perdida como já estava com o tempo a lembrança da sua procedência de uma vingança toda individual. O regime monárquico, que sucedeu à primitiva organização republicana, transferiu de Deus para os reis que, no espírito das sociedades bárbaras, 
com ele muitas vezes se identificavam, a fonte e a procedência de todo o direito de punir.

E daí concluiu-se a abstração do termo justiça, como representando a existência de um sentimento inato, impresso de todos os tempos na alma humana e correspondendo a existência de ordem superior, sem a menor ligação aos interesses materiais e egoísticos da vida terrena.

Mas a justiça conservou sempre, na sua significação etimológica coisa ordenada - os vestígios disfarçados da sua humildade genealógica.

III. Por conseguinte, para que se possa exigir de um povo que todos os seus representantes tenham o mesmo modo de sentir em relação ao crime, que formem todos da ação delituosa e punível o mesmo conceito, para que a pena, aferida pela imputabilidade, não se torne um absurdo, um contracenso, indispensável se faz que esse povo tenha chegado ao grau de homogeneidade que Tarde, inspirando-se nas suas teorias sobre a imitação, descreveu magistralmente como o elemento social da identidade em que, em sua teoria, faz ele consistir o critério da responsabilidade penal.

Para isso, é preciso, diz Tarde (Philosophie pénale), que as inclinações naturais, quaisquer que sejam, tenham recebido, em larga escala, do exemplo ambiente, da educação comum, do costume reinante, uma direção particular que as tenha especificado, que tenha precisado a fome na necessidade de comer iguarias francesas ou iguarias asiáticas, a sede na necessidade de beber vinho ou chá, o sentimento sexual no gosto de estilo mundano ou idílio campestre, em amor do baile em França ou dos bateis floridos na China, a curiosidade inata em paixão de viagens ou de leitura, de tais viagens ou de tais leituras, etc. Quando a sociedade tem fundido assim à sua imagem todas as funções e todas as tendências orgânicas do indivíduo, o indivíduo não faz um movimento, um gesto, que não seja orientado para um fim designado pela sociedade. Além disto, é preciso que, em larga escala também, as sensações brutas fornecidas pelo corpo e a natureza exterior em face um do outro, tenham sido profundamente elaboradas pelas convenções, pela instrução, pela tradição, e convertidas deste modo em um conjunto de ideias precisas, de juízos e de prejuízos, conformes em maioria às crenças dos outros, ao gênio da língua, ao espírito da religião ou da filosofia dominante, à autoridade dos avós ou dos grandes contemporâneos. Depois disto, pense o que pensar o indivíduo, ele há de pensar com o cérebro social, ele há de crer sob palavra nas suas maiores afoitezas de espírito e não fará mais do que repetir uma lição ensinada pela sociedade, ou combinar, se é livre e fecundo, repetição semelhantes em uma síntese original.

IV. Mas, se a análise científica derrui assim pela base a imutabilidade e o absolutismo das ideias de justiça e de direito, dando-lhes apenas um valor relativo e variável, submetido a exame igual não oferece maior consistência o pressuposto da vontade livre, critério e fundamento da imputabilidade.

Uma vez posta à margem a questão metafísica e insolúvel do livre arbítrio, o problema da vontade, tal como o pode estudar a psicologia científica, não escapa às contingências do desenvolvimento evolutivo da mentalidade humana.

No indivíduo, diz Ribot (Maladies de la volonté), a coordenação automática precede a coordenação nascida dos desejos e das paixões, que, por sua vez, precede a coordenação voluntária, cujas formas mais simples precedem as mais complexas.

No desenvolvimento das espécies (se admite a teoria da evolução), as forma inferiores da atividade existiram sós durante séculos; depois, com a complexidade crescente das coordenações, veio tempo em que a vontade apareceu.

Feito, pois, deste ponto de vista, o exame da questão da liberdade da vontade não nos pode deixar de levar à mesma conclusão a que, em conferência anterior, já cheguei pela análise psicológica direta.

Esta conclusão foi claramente formulada por Herbert Spencer nos seguintes termos:

Da lei universal, que, em igualdade de circunstâncias, a coesão dos estados psíquicos é proporcional à frequência com que eles se seguiram um ao outro na experiência, resulta o corolário inevitável que toda e qualquer ação deve ser determinada por essas conexões psíquicas que a experiência gerou, seja na vida do indivíduo, seja nessa vida geral anterior cujos resultados acumulados se tem organizado em sua constituição.

Apenas vos farei notar ainda que num grau de identidade social, como o descrito acima, as conexões psíquicas hereditárias devem constituir 
um fundo de ação comum a todos os membros da comunhão social, quase que podendo variar apenas as conexões psíquicas individuais.

V. De todo este estudo, que ainda constitui somente as premissas das conclusões cuja buscando eu para a legislação criminal brasileira, resulta, pois:

Que a cada fase da evolução social de um povo, e ainda melhor, a cada fase da evolução da humanidade, se comparam raças antropologicamente distintas, corresponde uma criminalidade própria, em harmonia e de acordo com o grau do seu desenvolvimento intelectual e moral.

Que há impossibilidade material, orgânica, a que os representantes das fases inferiores da evolução social passem bruscamente em uma só geração, sem transição lenta e gradual, ao grau de cultura mental e social das fases superiores; que, portanto, perante as conclusões tanto da sociologia, como da psicologia moderna, o postulado da vontade livre como base da responsabilidade penal, só se pode discutir sem flagrante absurdo, quando for aplicável a uma agremiação social muito homogênea, chegada a um mesmo grau de cultura mental média.

\section{CAPÍTULO II}

\section{O LIVRE ARBÍTRIO RELATIVO NOS CRIMINALISTAS BRASILEIROS}

Sumário - O livre arbítrio nos códigos criminais brasileiros. O livre arbítrio relativo defendido por Tobias Barreto. Erro substancial da sua teoria: a motivação psíquica implica o determinismo volicional. Argumentação contraproducente de Tobias Barreto. Perigo social do livre arbítrio, absoluto ou relativo.

Consagrei as duas últimas conferências à exposição sucinta do modo por que a ciência positiva moderna encara as questões de imputabilidade e criminalidade no ponto de vista da evolução social e mental. Estabeleci, ao mesmo tempo, as bases, os princípios gerais que nos hão de guiar no exame da questão aplicada, em particular, ao direito criminal brasileiro.

Era, pois, tempo de abordar o âmago da nossa tese. No entanto, a influência preponderante, que justamente exerceu sobre mais de uma geração brasileira um notável criminalista pátrio - cuja memória será sempre recordada com respeito e acatamento por todo espírito liberal e emancipado, tanto quanto tem ele sido caricaturado à farta pelos que vão tirar na copia e reprodução de suas doutrinas o que lhes negou, de próprio, o escasso merecimento -, me obriga a consagrar ainda a conferência de hoje ao exame de outra questão preliminar.

I. A legislação penal brasileira, seja no novo código da república, seja no antigo código do império, tomou por base o pressuposto espiritualista do livre arbítrio para critério da responsabilidade penal. Nisso não fez mais do que trilhar a doutrina penal corrente em todos os povos civilizados à europeia, reproduzida ainda recentemente no tão debatido código penal italiano.

Naturalmente esta doutrina é adotada em toda a sua plenitude e aceita com todas as suas consequências pelos partidários da metafísica espiritualista. Como tal, ela não exigiria aqui outra refutação além da que, de direito, se contém no exposto das lições anteriores. 
II. Entretanto, esta doutrina é ainda aceita, sob a forma de um ecletismo, de uma conciliação insustentável, por muitos representantes do mais puro determinismo.

Incidiu nesta contradição o eminente jurista brasileiro Tobias Barreto, no exame crítico a que submeteu o código de 1830 nos seus Menores e Loucos.

E, como somente em atenção à influência que este notável escritor exerceu no nosso país e ainda poderia exercer no espírito de alguns dos senhores, me proponho a examinar doutrinas conciliatórias do determinismo com o livre arbítrio, apenas me ocuparei aqui, dentre as suas múltiplas variedades, daquela que está consagrada na legislação penal alemã e foi adotada por Tobias Barreto.

Tobias Barreto, o monista, o evolucionista, que revolucionou o ensino do direito no Brasil, estacou ante a consequência fatal dos seus princípios filosóficos; consequências que ele próprio havia entrevisto na declaração de que "mais tarde ver-se-há na pena em nome de Darwin e de Hoeckel, alguma coisa semelhante à seleção espartana, ou uma espécie de seleção jurídica, pela qual os membros corruptos vão sendo postos à parte do organismo social comum".

Não teve, porém, a intuição prática dessa previsão, não soube antever que essa consequência lógica e natural da teoria evolucionista aplicada ao direito, havia de ser em breve formulada em corpo de doutrina para constituir, com os Ferri e Garofalo, a escola criminalista positivista.

Ante o receio da imputabilidade geral que havia de ser, no seu conceito, a consequência da condenação do livre arbítrio, ele constituiu-se adversário intransigente daqueles que tendem a identificar o crime com a loucura, os patólogos do crime na sua frase, e lançou-se em formal contradição, admitindo um livre arbítrio relativo, parcial, a ponto de fazer carga ao legislador brasileiro de não ter afirmado, expressamente, no código do império, o momento da liberdade como condição da imputação.

Com a vênia devida à autoridade de tanto peso, devo prevenir-vos contra os perigos da aceitação de tal doutrina. E por dever do cargo sou, pois, obrigado a entender-me com o egrégio professor a respeito de alguns pontos das suas teorias.

Para admitir e defender o livre orbitário, Tobias Barreto não duvidou mesmo renegar os seus princípios filosóficos.
Monista, truncou ele o verdadeiro monismo, o monismo científico ou natural, dando-lhe por coroamento o monismo filosófico de Noiré, que, no consórcio do movimento com o sentimento, achou meios de dar forma nova ao velho dualismo de todos os tempos.

Fino dialético, não viu que era um atentado contra a lógica aceitar a transição natural e sem hiato entre a matéria inorgânica e a orgânica e entre esta e a organizada, para pretender quebrar depois o elo que prende e subordina as leis psicológicas às da fisiologia.

Dizer depois disto que é "decidido sectário do monismo" e afirmar que "as leis da liberdade são as mesmas da natureza" é fazer uma afirmação puramente gratuita, para logo desmentida nas suas aplicações imediatas.

III. Se bem que compreendo Tobias Barreto, pretende ele que há erro da parte dos deterministas em acreditar que a motivação exclui a liberdade do querer, pois que a liberdade da vontade consiste exatamente em obrar de acordo com os motivos escolhidos "e quase sempre em oposição ao pendor da natureza, da mesma forma que se pode adquirir o habito de nadar contra as correntes".

“Os deterministas, diz ele (Questões vigentes, Pernambuco, 1888), entendem que o governo da natureza em relação ao homem, é sempre despótico e que não há vontade livre desde que os atos só se realizam em virtude de motivos". Se, com isto, Tobias Barreto quer dizer que, apesar das nossas tendências e atividades serem determinadas pelo meio e pela constituição pessoal, não existe obstáculo psíquico ao seu desenvolvimento; ou ainda, se quer referir-se à energia interior que possui cada um de nós, de se desenvolver de um modo especial com uma reação própria contra as influencias do meio; então, como observa Enrico Ferri que tirou este ponto completamente a limpo, não há o menor desacordo entre a sua opinião e a que sustentam os deterministas.

Somente em nada isso prova a existência da liberdade da vontade.

Com efeito, não são só as ações humanas que, apesar de determinadas por causas naturais, podem se desenvolver livremente, sem embaraço de ordem física, mas, sim todos os fenômenos da natureza. Então, como exemplifica Ferri, as águas de um rio, que correm de acordo com as leis da gravidade, se podem dizer livres. 
A individuação nas ações humanas prova ainda mais neste sentido, visto como é exatamente porque "toda a ação humana é o efeito necessário de certas causas determinantes, com exclusão de outras, que todo homem tem uma personalidade sua - física e moral".

Tobias Barreto afirma, sem razão, que os deterministas fundamentam a negação do livre arbítrio no fato bruto da motivação das ações humanas, e que se lhes podem objetar, como prova da existência de uma certa dose da liberdade do querer, a escolha psíquica dos motivos e a possibilidade da determinação no sentido da maior resistência.

Em tudo isto, no entanto, não há mais do que uma aparência ilusória de liberdade da qual, de fato, a consciência, como cúmplice, nos dá falaz testemunho. Mas uma pura alusão não pode servir, como admite TobiasBarreto, de critério e de base à doutrina da responsabilidade penal.

A escolha dos motivos, bem como a determinação no sentido da maior resistência, "o nadar contra as correntes", não são manifestações da liberdade, mas tão somente a resultante da organização psícofisiológica do indivíduo.

Para deixar-vos perfeitamente edificados sobre este ponto, não posso fazer melhor do que dar-vos por inteiro a citação dos seguintes trechos, extensos mas substanciosos, em que todos estes fenômenos são submetidos a uma fina e delicada análise psicológica.

Mas, considerada no fundo, o que é a escolha psíquica? Pergunta Ribot (Les maladies de la volonté). Insistamos sobre este ponto fundamental, diz ele, e procuremos esclarecê-lo. Descendo a alguns fatos biológicos muito humildes, talvez vejamos melhor em que consiste uma escolha. Para não me perder em analogias remotas, não direi palavra da afinidade física (do ímã para o ferro, por exemplo). No reino vegetal, somente lembrei que as plantas insetívoras, como a dionéa, escolhem, com exclusão dos outros, certos corpos que chegam a seu contato. Da mesma maneira, a ameba escolhe certos fragmentos orgânicos de que se nutre. Estes fatos são incontestáveis: a interpretação é difícil. Em geral, se explicam por uma relação de composição molecular entre o que escolhe e o que é escolhido. Sem dúvida aqui a escolha se exerce num campo muito restrito; mas também é a sua fornia mais grosseira, quase física. O nascimento e o desenvolvimento de um sistema nervoso, cada vez mais complexo, transformam esta afinidade cega em uma tendência consciente, depois em muitas tendências contraditórias das quais uma predomina - a que representa o máximo de afinidade (o cão que hesita entre muitos alimentos e acaba por escolher um). Mas sempre a escolha exprime a natureza do indivíduo, num momento dado, em circunstâncias dadas, e em um grão dado; isto é, que quanto mais fraca é a afinidade, tanto menos decidida é a preferência. Podemos dizer, pois, que a escolha - resulte ela de uma tendência, de muitas tendências, de uma sensação presente, de imagens recordadas, de ideias complexas, de cálculos complicados e projetados no futuro - funda-se sempre numa afinidade, numa analogia de natureza, em uma adaptação. Isto é tão verdadeiro do animal inferior ou superior, como do homem, para o vicio ou para a virtude, para a ciência, o prazer ou a ambição. Para nos limitar ao homem, figuremos, como exemplo, que dois ou muitos estados de consciência surgem como fins possíveis de ação: após oscilações, um é escolhido, preferido. Por quê? - senão porque, entre este estado e a soma de estados conscientes, subconscientes e inconscientes (puramente fisiológicos) que constituem neste momento a pessoa, o eu, há conveniência, analogia de natureza, afinidade? É a única explicação possível da escolha, a menos que não se admita que ela não tem causa... Todo animal, privado ou dotado de razão, são ou doente, não pode querer senão o que lhe parece, no momento atual, o seu maior prazer, ou o seu menor mal. O próprio homem que prefere a morte à desonra ou à apostasia (nadar contra as correntes) escolhe o partido menos desagradável. $\mathrm{O}$ caráter individual e o desenvolvimento da razão fazem com que a escolha ora suba muito alto, ora caia muito baixo; mas tende sempre para o que agrada mais. O contrário é impossível. Uma verdade psicológica tão clara que os antigos tinham feito dela um axioma e foram precisos volumes de metafísica para obscurecê-la.

Não é menos completa e magistral a explicação, ou antes a interpretação natural da ação no sentido da maior resistência.

Salvo a nossa ignorância, diz ainda Ribot, não temos, pois, razão alguma para atribuir ao esforço volicional um caráter à parte do esforço muscular. Em todos os casos em que este esforço deve se produzir, surge sempre o seguinte problema - os elementos nervosos são capazes de fornecer um excesso de trabalho durante um período dado? Ou então, por natureza, por falta de educação e de exercício, esgotam-se rapidamente e ficam incapazes de recobrar novas forças? Têm eles, sim ou não, uma qualidade suficiente de força disponível armazenada em si? O problema da ação no sentido da maior resistência acha-se reduzido assim aos seus termos últimos. É esse 
trabalho oculto, quase desconhecido, que se traduz pelo sentimento do esforço volicional. $\mathrm{O}$ sentimento de esforço, sob todas as suas formas, é, pois, um estado subjetivo que corresponde a certos fenômenos que se passam nos centros nervosos e em outras partes do organismo, mas que se assemelham tão pouco a eles quanto as sensações de som e de luz, assemelham-se a sua causa objetiva. Para ser capaz de grandes esforços musculares, é preciso que os centros nervosos adaptados achem-se em estado de produzir um trabalho considerável e prolongado; o que depende de sua natureza e da rapidez em reparar as suas perdas. Para produzir um grande esforço moral ou intelectual, é preciso, do mesmo modo, que os centros nervosos adaptados a esse fim (quaisquer que eles sejam, e a nossa ignorância a este respeito é quase completa) estejam em condições de produzir um trabalho intenso e repetido, ao invés de se esgotar rápida e definitivamente. A possibilidade do esforço é, pois, em última análise, um dom natural.

Convém explicar-vos que esta maior resistência é representada pelas tendências inferiores da organização psicofisiológica, em luta com as tendências superiores, de adaptação mais complexa, porém menos fortes por serem mais recentes.

Não é menos positivo o modo por que se enuncia e condena a opinião de Tobias Barreto um autor que não lhe pode ser suspeito, porque quase escapou da ojeriza galofóbica do ilustre e eminente professor.

A liberdade, diz Eugenio Veron (La Morale, Paris, 1884), não se deve procurá-la nos arrebatamentos dos selvagens, nem nos assomos de paixão em que evidentemente o homem não é mais do que o joguete da força desordenada que o domina. Se ela pode ser encontrada em alguma parte, é na deliberação tranquila e calma que institui em si mesmo o homem razoável, quando opõe motivos, os estuda, os compara, examina as suas consequências, as suas soluções no ponto de vista do seu interesse individual e do interesse social. Após este exame atento - e depende dele prestar a isso maior ou menor atenção - escolhe o que lhe parece mais conforme ao que considera como o fim mais desejável. Esta conformidade reconhecida produz nele uma convicção que se impõe à sua ação. Toda oposição tem então desaparecido, porque já não subsiste mais do que um só motivo de agir; e esta ausência de oposição é justamente o que pode dialogar a ilusão da liberdade. Na realidade, porém, é sempre, como estabelecemos, o motivo mais forte que predomina; somente a pesada dos motivos se tem produzido em condições de calma e de reflexão, que afastam toda ideia de violência e submissão. Nem por isso é menos verdade que esta liberdade é sempre uma aparência, pois que, em suma, ela se limitou a escolher o motivo que reconheceu mais conforme às necessidades do indivíduo; ora, essas necessidades resultam fatalmente da constituição humana. A conformidade do motivo com a necessidade não depende mais da vontade do homem, do que o reconhecimento desta conformidade depende do capricho da inteligência.

Se depois desta análise da escolha volicional, tão completa e magistral, é ainda possível afirmar que o homem é livre; se ainda é licito acreditar que, na ilusão de liberdade que nos dá a consciência, há alguma realidade; então não sei que valor podem ter as deduções da lógica, nem que significação possam adquirir os frutos de sã observação científica.

E esta análise tanto se refere e compreende o livre arbítrio dos metafísicos, como a liberdade parcial, dos espíritos timoratos e indecisos.

É claro, diz com razão Enrico Ferri (La Sociologie criminalle, Paris, 1893), que todos os raciocínios lógicos e de fato que se dirigem contra o livre arbítrio absoluto, destroem igualmente o livre arbítrio relativo, porque as objeções que valem contra um metro de liberdade, valem também contra um centímetro da mesma liberdade.

IV. A conciliação impossível que tenta Tobias Barreto entre o determinismo e o livre arbítrio acha a sua condenação a cada passo, nos próprios argumentos em que ele procura firmá-la.

Pretende ele, por exemplo, que se pode tirar uma nova prova da existência da liberdade, do fato de estar à seleção social - que ele supõe um produto da vontade humana - em constante contradição com a seleção, "sendo uma série de combates contra o geral combate pela existência".

Compreendo que admitida a seleção social como um produto da vontade humana, se possa concluir daí que a vontade é uma causa, o que ninguém contesta.

Mas não compreendo como se possa concluir que a vontade é livre. Porque contraria a seleção natural, não. Pois, a seleção natural não se faz rigorosamente em linha reta e a adaptação de seres relativamente aperfeiçoados a certos meios pode ter como consequência até uma regressão morfológica.

É o que se dá com os parasitas. 
Outra série de exemplos notáveis de adaptação correlativa, diz Hoeckel (Histoire de la Création, 1877), nos é fornecida pelos diversos animais e vegetais, que se adaptando a uma vida de parasita, são feridos de retrogradação. Nenhuma outra mudança de gênero de vida atua tanto sobre o desenvolvimento de um organismo como o costume à vida parasita. Animais que, precedentemente viviam independentes e livres, perdem inteiramente, tornando-se parasitas de animais ou plantas, a atividade dos seus órgãos do movimento ou dos sentidos. Mas a perda da atividade acarreta a perda dos órgãos pelos quais se manifestava essa atividade e então, se vê, por exemplo, numerosos crustáceos, que, depois de haver possuído na mocidade um grão elevado de organização, patas, palpos táteis, olhos, degeneram com a idade, quando se tem tornado parasitas perfeitos, e então não possuem mais nem olhos, nem órgãos do movimento, nem palpos táteis. A forma transitória da mocidade, movei e ágil, se transforma em massa informe, imóvel. Só os órgãos mais indispensáveis, os da nutrição e da geração, conservam a atividade. Todo o resto do corpo é tocado de retrogradação.

Tobias Barreto não consideraria, por certo,esta adaptação regressiva uma manifestação voluntaria e livre, somente por ter ela contrariado a direção primitiva da seleção natural.

Não é menos superficial e contraproducente a objeção tirada da impulsividade epilética..

$\mathrm{O}$ ato impulsivo não é, como afirma Tobias Barreto, um ato sem motivos, pois na motivação psíquica, além dos motivos externos, objetivos, aparentes, os fins da ação, a que se referia Trousseau, citado por Tobias Barreto, há ainda os motivos internos, organizados, hereditários ou adquiridos, e inconscientes ou subconscientes.

Variando desde o automatismo reflexo até a impotência voluntaria consciente, os atos impulsivos depõem, ao contrário, contra a existência de uma vontade livre. O estudo da desorganização do ato volitivo nas impulsões irresistíveis é muito instrutivo. A deixa a descoberto o mecanismo psicológico da determinação voluntaria e permite verificar a sua subordinação às leis gerais da motivação.

Não é menos incompreensível, do ponto de vista do livre arbítrio, a declaração de Tobias Barreto de que ele "considera o crime como uma das mais claras manifestações do princípio naturalístico da hereditariedade".
Não aproveita, não atenua e pelo contrário agrava ainda mais esta contradição a sua comparação das modificações possíveis da vontade (ele diz índole, isto é, caráter) com as modificações da cor nas pétalas da flor e nas plumas das aves.

Se por força da seleção natural ou artística, diz ele, até às aves mudam a cor das plumas e às flores a cor das pétalas, por que razão, em virtude do mesmo processo, não poderia o homem mudar direção da sua índole?

A comparação pode ser poética, mas não é lógica.

Nesta comparação, fica-se na alternativa seguinte: ou acreditar que estes fenômenos naturais são voluntários, o que é absurdo no ponto de vista do livre arbítrio humano; ou aceitar o código como fator de seleção natural da mesma espécie e natureza que os fatores da seleção nos vegetais - como eu aceito - mas neste caso é preciso sacrificar o livre arbítrio.

Dos esforços de Tobias Barreto neste sentido pode-se repetir o que o Dr. Clovis Bevilaqua escreveu de Fouilée.

Dado o princípio da causalidade, diz ele (Sobre uma nova teoria da responsabilidade, Recife, 1892), como traduzindo abstratamente o modo uniforme pelo qual se realizam os fenômenos de todo o cosmo, e admitida a unidade evolucional dos mundos, inorgânico e orgânico, do físico e do psíquico, o livre arbítrio se afigura como uma incongruência, como um sonho criado pela imaginação para fugir às contingências desta existência fenomênica. E é desta desproporção fundamental entre o conceito do livre arbítrio e os elementos imediatos da nossa cognição que resulta a inanidade de todos os esforços para conciliá-lo com o determinismo.

Não preciso examinar mais em detalhe a teoria do livre arbítrio relativo de Tobias Barreto sob a sua forma alemã de liberdade da inteligência. Aqui, como faz notar Ferri, analisando o art. 51 do código penal alemão, o livre arbítrio expulso pela porta da vontade, é admitido pela janela da inteligência.

Inadmissível sob a forma de independência de causas internas e externas, a liberdade da inteligência, mesmo sob a forma da sua normalidade, implica o livre arbítrio. 
V. De nada valeu, entretanto, o sacrifício da contradição do eminente jurista. Livre arbítrio absoluto, ou relativo, é claro que a doutrina criminal que sobre ele fizer repousar a responsabilidade, há de conduzir fatalmente à impunidade.

A psiquiatria moderna amplia todos os dias os seus domínios a todo o instante dilatam mais e mais ao campo de ação das causas atenuantes ou dirimentes da responsabilidade. E basta refletir um instante sobre a marcha sempre crescente do prestígio da freniatria legal, do meio para o fim de presente século, para se concluir que, com o atual sistema de repressão, em época pouco remota, há de estar infalivelmente satisfeito o desideratum asilo em vez de prisão -, dos tão mal vistos patólogos do crime.

Conclui-se a lista das causas que, no conceito dos alienistas modernos, dirimem ou atenuam a responsabilidade penal; consulte-se Riant ou Thierry e a conclusão é que em rigor a poucos criminosos não aproveitarão os benefícios da irresponsabilidade.

\section{E nem podia ser de outro modo.}

Desde que os alienistas, peritos natos na matéria, se educam todos no espírito positivo e determinista da psicologia moderna; desde que por sua vez esta demonstra e prega a subordinação fatal de toda determinação, suposta voluntária, a conexões psíquicas anteriores; era necessária a conclusão de que, quanto mais profunda e competente for a análise psicológica do criminoso, quanto mais adiantados e aperfeiçoados estiverem os conhecimentos da psicologia mórbida, tanto mais fácil será descobrir moveis de ação, inteiramente alheios a influência da vontade livre e por conseguinte tanto mais numerosas serão as declarações de irresponsabilidade e mais frequentes as absolvições.

Não é um médico, mas, sim um criminalista notável, Tarde (Philosophie pénale), quem aprecia a questão nos seguintes termos:

Ao médico perito, incumbido, em um número crescente de casos, de apreciar o estado mental do culpado, torna-se cada vez mais difícil emitir a opinião de que este era livre em querer de modo diverso do que quis. Se o médico exprime esta opinião, é violentando as suas convicções cientificas. Um médico legista, Dr. Mendel, publicou um trabalho destinado a provar que os seus colegas devem se abster de responder ao quesito: o acusado estava no gozo de seu livre arbítrio?
Virchow e outras notabilidades médicas adotam esta opinião. Eles têm razão: pensar de outro modo é, da parte de um perito determinista, sacrificar a lógica à utilidade, a sinceridade talvez à rotina. Por outro lado, perante os tribunais, torna-se cada vez mais fácil ao advogado, com os escritos dos alienistas em punho, demonstrar o caráter irresistível das impulsões criminosas que arrastaram o seu cliente; e, tanto para o jurado como para o legislador a irresponsabilidade do acusado é a consequência.

Vede, pois, senhores: a doutrina do livre arbítrio relativo nos leva exatamente a essa perigosa impunidade geral, a que procurava fugir Tobias Barreto. E era contra esta consequência que eu queria e tinha o dever de prevenir-vos.

Enxertando, como faz o ecletismo, os dados científicos da biossociologia criminal no velho tronco das teorias clássicas, diz Ferri (loc. cit.), acontece que nem temos os frutos que esses dados produziriam por meio de uma aplicação completa e lógica, nem os efeitos que logicamente, apesar do seu desacordo com a realidade das cousas, trariam os princípios clássicos em seu absolutismo.

O que sucede na prática, tinha dito ele antes - e o que doravante é um verdadeiro perigo social das teorias clássicas -, é uma espécie de impunidade, ou semi-impunidade ou semi-impunidade geral, um verdadeiro jubileu sobretudo para os criminosos mais perigosos.

O exame da responsabilidade das raças brasileiras nos nossos códigos penais vai ministrar um novo exemplo desse dilema em que se debatem os criminalistas clássicos: ou punir sacrificando o princípio do livre arbítrio, ou respeitar esse princípio, prejudicando a segurança social. 


\section{CAPÍTULO III}

\section{AS RAÇAS HUMANAS NOS CÓDIGOS PENAIS BRASILEIROS}

Sumário - O livre arbítrio penal em contradição com a punição dos crimes involuntários: na sua maioria, são desta natureza os crimes das raças inferiores julgadas pelos códigos dos povos civilizados. A responsabilidade completa das raças inferiores nos códigos penais brasileiros. Jus que fazem à irresponsabilidade por insuficiência da consciência do direito do dever. Tendência inata à involuntária à impulsividade por insuficiência de desenvolvimento psíquico.

I. Os criminalistas positivistas terão demonstrado à sociedade que atos inteiramente independentes da vontade dos que são por eles responsabilizados figuram previstos nos diversos códigos e punidos como verdadeiros crimes.

O homicídio involuntário, os ferimentos por imprevidência, a solidariedade familiar antiga que punia o crime em um parente ou qualquer membro da tribo do criminoso, a responsabilidade dos pais e senhores pelos atos dos filhos e servos, os crimes de opiniões e convicções, gênero em que "cada auto de fé constitui um protesto eloquente contra a teoria clássica"; em todos estes casos em que nem sequer era lícito cogitar, no punido, de intenção ou vontade de delinquir, os códigos penais que baseiam a responsabilidade na liberdade do querer, prescindem, sem mais explicações, desse elemento que devia ser constitutivo e fundamental da ação criminosa.

A igualdade das diversas raças brasileiras perante o nosso código penal vai acrescentar mais um aos numerosos exemplos dessa contradição e inconsequência.

A imputação moral, como base e condição da responsabilidade penal, era expressamente estabelecida nos Arts. 2, 3 e 13 do código do império, e acha-se formulada nos artigos 7, 8, 27 e 30 do código vigente. Como natural consequência admitem eles a existência de causas capazes de agravar, atenuar e dirimir a responsabilidade penal.
Mas, nem como causa dirimente, nem como causa atenuante da responsabilidade penal, figura neles o momento da consideração de raça. Tal intenção e alcance não se podem atribuir ao $1 .^{\circ}$ do art. 42 , pois que, para aceitar esta doutrina, era mister que houvesse no código alguma disposição correspondente aos casos extremos em que, por consideração, ou momento antropológico, desaparece de todo a responsabilidade penal, o art, $4 .^{\circ}$ do código vigente dispõe expressamente: "A lei penal é aplicável a todos os indivíduos, sem distinção de nacionalidade, que, em território brasileiro, praticarem fatos criminosos e puníveis".

Desconhecendo a grande lei biológica que considera a evolução ontogênica simples recapitulação abreviada da evolução filogenia, o legislador brasileiro cercou a infância do indivíduo das garantias da impunidade por imaturidade mental, criando a seu beneficio as regalias da raça, considerando iguais perante o código os descendentes do europeu civilizado, os filhos das tribos selvagens da América do Sul, bem como os membros das hordas africanas, sujeitos à escravidão.

Quando escravos, os americanos e africanos, longe de encontrar proteção e benevolência na lei penal, tinham nela o extremo rigor do art. $1 .{ }^{\circ}$ da lei de 10 de Junho de 1835, que punia de morte não só o assassinato como as ofensas físicas graves cometidas contra os seus senhores.

Dos efeitos práticos da igualdade das raças brasileiras perante o código penal, instrui-nos bastante a seguinte estatística, relativa a um período de oito anos, que eu confeccionei com as notas e assentos dos livros, que da nossa penitenciária, quando ali me entregava a estudos de outra ordem.

Sentenciados por crime:

\begin{tabular}{|l|c|}
\hline \multicolumn{2}{|c|}{ De homicídios } \\
\hline Brancos & 55 \\
Índios & 2 \\
Africanos & 2 \\
Negros Crioulos & 76 \\
Mulatos & 7 \\
Cabras & 56 \\
Caboclos & 28 \\
Pardos & 175 \\
\hline
\end{tabular}

\begin{tabular}{|l|c|}
\hline \multicolumn{2}{|c|}{ De lesões corporais } \\
\hline Brancos & 20 \\
Negros Crioulos & 22 \\
Mulatos & 3 \\
Cabras & 8 \\
Caboclos & 4 \\
Pardos & 43 \\
\hline
\end{tabular}




\begin{tabular}{|l|c|}
\hline \multicolumn{2}{|c|}{ De furtos e roubos } \\
\hline Brancos & 31 \\
Negros Crioulos & 18 \\
Mulatos & 5 \\
Cabras & 14 \\
Caboclos & 6 \\
Pardos & 41 \\
\hline
\end{tabular}

\begin{tabular}{|l|l|}
\hline \multicolumn{2}{|c|}{ Estupros } \\
\hline Negro Crioulo & 1 \\
Mulato & 1 \\
Cabras & 3 \\
Pardos & 4 \\
\hline
\end{tabular}

Os erros cometidos na classificação dos mestiços fazem com que esta pequena estatística não possa ter outra serventia além da de demonstrar que o nosso código pode indistintamente levar à penitenciária brasileiros de qualquer das raças.

Da conduta adotada na Bahia para a repressão dos crimes cometidos pelos indígenas americanos, o Dr. Sá e Oliveira, digno preparador desta cadeira e meu distinto auxiliar neste ensino, ministra-nos informações curiosas.

Residiu ele por longos anos no sul do estado, em zona em que avalia existir ainda cerca de mil índios mais ou menos selvagens.

Os índios domesticados, ditos civilizados, respondem ali por seus crimes perante os tribunais do país, como qualquer outro brasileiro. Para os selvagens, porém, existe ainda hoje uma justiça sumária que consiste em caçálos como a bestas feras, vingando-se em verdadeiras hecatombes de aldeias inteiras, os assaltos ou crimes cometidos contra os povoados mais próximos.

Observa o Dr. Sá que este proceder em nada escandaliza a opinião pública, em nada afeta o sentimento de piedade daquela população rústica que não se pode conformar com a ideia de que os selvagens tenham direito e deveres iguais aos seus, ainda quando esse direito seja o direito à vida.

II. Do ponto de vista do livre arbítrio, absoluto ou relativo, tudo isto é bem iníquo e injusto.

Porque razão, inquire Ferri, nessa pretendida avaliação da liberdade moral dos criminosos, haveis de limitar-vos sempre só às circunstâncias clássicas e tradicionais, que são consideradas capazes de influir sobre a responsabilidade e taxativamente fixadas nos tratados e nos códigos: menoridade, surdo-mudez, loucura, embriaguez, sono? E porque não admitir o grão de instrução e educação recebidas, os metros cúbicos de ar respirado nas pocilgas das nossas grandes cidades, numa promiscuidade horrível de membros nus e sujos, ou nas habitações miseráveis dos camponeses; porque não admitir a profissão, o estado civil, as condições econômicas, o temperamento nervoso ou sanguíneo do acusado? Por acaso, a liberdade moral depende somente dessas quatro ou cinco circunstâncias taxativas, e todas as outras devem ser compreendidas na expressão vaga de circunstâncias atenuantes, a qual, por sua vez, não é mais do que um compromisso entre a lógica e a justiça?

Porque, pois, não admitir também a raça? Pergunto eu.

Com efeito. "para que haja imputabilidade, isto é, responsabilidade penal, diz Berner, se deve ter a consciência de si mesma, a consciência do mundo exterior, e a consciência desenvolvida do dever".

É a ideia que Tobias Barreto, sectário da mesma escola alemã de Berner, desenvolve quase em termos idênticos.

A ideia do criminoso, escreve Tobias Barreto (Menores e Loucos), envolve a ideia de um espírito que se acha no exercício regular das suas funções, e tem, portanto atravessado os quatro seguintes momentos da evolução individual: $1 .^{\circ}$ a consciência de si mesmo; $2 .^{\circ}$ a consciência do mundo externo; $3 .^{\circ}$ a consciência do dever; $4 .^{\circ}$ a consciência do direito. $\mathrm{O}$ estado de irresponsabilidade por causa de uma passageira ou duradoura perturbação do espírito, na maioria dos casos, é um estado de perda das duas primeiras formas da consciência, ou da normalidade mental. Não assim, porém, quanto à carência de imputação das pessoas de tenra idade, e em geral de todos aqueles que não atingiram um desenvolvimento suficiente; neste caso, o que não existe, ou pelo menos se questiona se existe ou não, é a consciência do dever e algumas vezes também a consciência do direito.

Ora, é obvio que a inconsciência do direito e do seu correlativo o dever pode revestir duas formas distintas. A inconsciência temporária e transitória como no caso da menoridade, e a inconsciência do direito e do dever nos casos de colisão de povos em fases muito diferente da evolução sociológica. Nestes casos, é a preexistência da consciência do direito e do dever, inerentes às civilizações inferiores, que exclui e impossibilita a consciência do direito, tal como o entendem os povos civilizados, ou superiores sociologicamente.

Já ficou assentado: o direito é um conceito relativo, e variável com as fases do desenvolvimento social da humanidade. 
Bem como as artes, bem como as ciências, diz o próprio Tobias Barreto, o direito é um produto da cultura humana; fora desta, em qualquer grau que ele seja, nenhum direito, nenhuma disciplina das forças sociais. Os chamados direitos naturais e originários como o direito à vida, à liberdade, e poucos outros, nunca existiram fora da sociedade: foi esta quem os instituiu e consagrou. Uma das melhores provas de que a concepção de um tal direito é simplesmente o resultado do espírito de uma época, nós achamo-la na consideração seguinte: o direito natural dos tempos modernos é inteiramente diverso do jus naturale dos romanos; quem nos pode garantir que para o futuro o conceito de um direito natural não será tão diferente do hodierno quanto este é diverso do romano?

Se, por conseguinte, os romanos existissem ainda hoje, no grau de civilização e com a organização social daquele tempo - como acontece com outros povos que ainda permanecem em pleno período bárbaro ou selvagem -, é claro que não se poderia exigir deles como momento constitutivo da sua criminalidade, a consciência do direito natural moderno. E, se por ignorância, ou preconceitos doutrinários se insistisse em aplicar ao seu julgamento o conceito do direito moderno, teríamos de ver muito benemérito daquelas épocas receber nas nossas penitenciárias o prêmio das suas virtudes.

O desenvolvimento e a cultura mental permitem seguramente às raças superiores apreciarem e julgarem as fases por que vai passando a consciência do direito e do dever nas raças inferiores, e lhes permitem mesmo traçar a marcha que o desenvolvimento dessa consciência seguiu no seu aperfeiçoamento gradual.

Mas esta aquisição, puramente cognoscitiva, nenhuma influência pode ter na conduta dos povos civilizados. As condições existenciais da sua sociedade tendo variado, com elas variou o conceito do direito e do dever.

As condições existenciais das sociedades, em que vivem as raças inferiores, impõem-lhes também uma consciência do direito e do dever, especial, muito diversa e às vezes mesmo antagônica daquela que possuem os povos cultos.

Mas, a esta circunstância, que já os impedia de ter a mesma consciência do direito e do dever, acresce que a sua organização fisiopsicológica não comporta a imposição revolucionaria de uma concepção social, e de todos os sentimentos que lhe são inerentes, a que só puderam chegar os povos cultos evolutivamente, pela acumulação hereditária gradual do aperfeiçoamento psíquico que se operou no decurso de muitas gerações, durante a sua passagem da selvageria ou da barbaria à civilização.

Ora, desde que a consciência do direito e do dever, correlativos de cada civilização, não é o fruto do esforço individual e independente de cada representante seu; desde que eles não são livres de tê-la ou não tê-la assim, pois que essa consciência é, de fato, o produto de uma organização psíquica que se formou lentamente sob a influência dos esforços acumulados e da cultura de muitas gerações; tão absurdo e iníquo, do ponto de vista da vontade livre, é tornar os bárbaros e selvagens responsáveis por não possuir ainda essa consciência, como seria iníquo e pueril punir os menores antes da maturidade mental por já não serem adultos, ou os loucos por não serem sãos de espírito.

Para habilitar-vos a julgar da extensão que ganharia a impunidade com a aplicação ao nosso código desta desconveniência entre a consciência do direito e do dever nos povos civilizados e nas raças selvagens, convém dizê-los que a observação constata nestas últimas, uma como diminuição do campo da consciência social, de modo que o conceito do crime restringe-se por demais, aplicando-se apenas a um ou outro ato excepcional.

"Como nos animais, diz Lombroso (Medicina Legal), o delito nos selvagens não é mais a exceção, é a regra quase geral". Evidentemente Lombroso julga aqui as ações dos selvagens, pelo critério de criminalidade dos povos cultos, pois que propõe-se ele exatamente a demonstrar que, salvo pequenas exceções, os atos tidos por criminosos nos povos civilizados confundem-se nos selvagens com os atos comuns, permitidos e até obrigatórios. Na revista que ele passa a todos os domínios da atividade criminosa, esta ideia salienta-se e acha plena confirmação.

"O homem diz ele, só passou da Vênus Promíscua à Vênus Monógama através de usos que nós consideramos delitos, tais como a poligamia, o incesto, e, pior, o estupro e o rapto".

Não é menos demonstrativa a análise dos atentados contra as pessoas, sejam estas embrião, feto, criança ou adulto. O aborto, o infanticídio, o homicídio eram praticados, permitidos por lei e santificados pela religião. Quem ignora a existência da arte de furtar como instituição social?

Por este modo se pode avaliar a soma de atentados que, numa colisão de povos civilizados com povos selvagens, a cada passo podiam estes 
cometer contra as condições existenciais da sociedade culta, sem que no foro íntimo da sua consciência o sentimento do direito e do dever os tornassem deles responsáveis.

A alma do direito, escreveu Ferri, é a igualdade, seja moral e ideal, seja física e orgânica. Se um homem civilizado encontrasse um selvagem dos mais primitivos, entre eles não poderia haver uma regra de direito por causa da excessiva diferença de raça.

Consoante com este acerto de Ferri, no Brasil a consciência do direito, como base da imputação criminal, pode fazer variar esta a negação de qualquer comunidade de direitos, e portanto da negação da criminalidade entre um selvagem e um civilizado, até a sua afirmação completa entre dois civilizados. Mas, de um destes extremos ao outro, resta sempre larga margem, para uma atenuação, mais ou menos considerável, da responsabilidade, na hipótese de um conflito entre civilizados e semicivilizados. Nestes casos, que são os mais comuns entre nós, a igualdade política não pode compensar a desigualdade moral e física.

Todavia, este não é um dos títulos por que as raças inferiores no Brasil podem disputar os benefícios da impunidade perante um código que faz repousar a responsabilidade penal sobre o livre arbítrio.

Se, de fato, a evolução mental na espécie humana é uma verdade, à medida que descermos a escala evolutiva, a mais e mais nós deveremos aproximar das ações automáticas e reflexas iniciais. Deste jeito, nas raças inferiores, a impulsividade primitiva, fonte e origem de atos violentos e antissociais, por muito predominarão sobre as ações refletidas e adaptadas, que só se tornaram possíveis, nas raças cultas e nos povos civilizados, com o aparecimento de motivos psíquicos de uma ordem moral mais elevada.

Entretanto, em rigor, esta nova ordem de irresponsabilidade para as raças inferiores no Brasil - que havendo de desenvolver nas lições subsequentes -, não é, de fato, mais do que outra face apenas do assunto discutido nesta lição.

Com efeito, as condições existenciais de cada sociedade, das quais se origina e procede todo o direito, não são em última análise senão o resultado da sua capacidade mental - efeito e causa ao mesmo tempo da evolução social -, de sorte que é sempre na psicologia das raças humanas existentes no Brasil que havemos de procurar a capacidade delas para o exercício das regras, de direito, que as regem.

\section{CAPÍTULO IV}

\section{O BRASIL ANTROPOLÓGICO E ÉTNICO}

Sumário - Elementos antropológicos da população brasileira; raças puras, mestiços. Composição étnica do povo brasileiro: divisão étnica do país em quatro grandes zonas ou regiões. Caracteres físicos e climatológicos dessas regiões.

No ponto de vista histórico e social penso com o Dr. Sylvio Romero: todo brasileiro é mestiço, se não no sangue, pelo menos nas ideias.

Mas, no ponto de vista do direito penal, que ora nos ocupa, faz-se preciso considerar, no povo brasileiro, todos os elementos antropológicos distintos, como que ele atualmente se compõe.

I. A prima face, pode-se distinguir na população brasileira atual uma grande maioria de mestiços em graus muito variados de cruzamento, e uma minoria de elementos antropológicos puros ${ }^{1}$ não cruzados. Estes compreendem:

a) a raça branca, representada pelos brancos, crioulos não mesclados e pelos europeus, ou de raça latina, principalmente portugueses e hoje italianos em São Paulo, Minas, etc., ou de raça germânica, os teuto-brasileiros do sul da república;

b) a raça negra, representada pelos poucos africanos ainda existentes no Brasil, principalmente neste estado, e pelos negros crioulos não mesclados;

c) a raça vermelha, ou indígena, representada pelo brasílio-guarani selvagem que ainda vagueia nas florestas dos grandes estados do oeste e extremo norte, assim como em alguns pontos de outros estados, tais como Bahia, São Paulo, Maranhão, etc., e pelos seus descendentes civilizados, mais raros e só observados nos pontos vizinhos dos recessos a que se tem refugiado os selvagens.

${ }^{1} \mathrm{O}$ termo puro tem aqui apenas um valor relativo o se opõe tão somente ao mestiçamento que assistimos. 
Por seu turno, os mestiços brasileiros carecem de unidade antropológica e também podem ser distribuídos por um número variável de classes; ou grupos. ${ }^{2}$

Os mestiços compreendem:

$1^{\circ}$ os mulatos, produto do cruzamento do branco com o negro, grupo muito numeroso, constituindo quase toda a população de certas regiões do país, e divisível em: a) mulatos dos primeiros sangues; b) mulatos claros, de retorno à raça branca e que ameaçam absorvê-la de todo; c) mulatos escuros, cabras, produto de retorno à raça negra, uns quase completamente confundidos com os negros crioulos, outros de mais fácil distinção ainda;

$2^{\circ}$ os mamelucos ou caboclos, produto do cruzamento do branco com o índio, muito numerosos em certas regiões, na Amazônia por exemplo, onde, ad instar do que fiz com os mulatos, se poderá talvez admitir três grupos diferentes. Aqui na Bahia, basta dividi-los em dois grupos: dos mamelucos que se aproximam e se confundem com a raça branca, e dos verdadeiros caboclos, mestiços dos primeiros sangues, cada vez mais raros entre nós;

$3^{\mathrm{o}}$ os curibocas ou cafuzos, produto do cruzamento do negro com o índio. Este mestiço é extremamente raro na população da capital. Creio seja mais frequente em alguns pontos do estado e muito frequente em certas regiões do país, na Amazônia ainda;

$4^{\circ}$ os pardos, produto do cruzamento das três raças e proveniente principalmente do cruzamento do mulato com o índio, ou com os mamelucos caboclos.

Este mestiço, que, no caso de uma mistura equivalente das três raças, devia ser o produto brasileiro por excelência, é muito mais numeroso do que realmente se supõe. Pretendo demonstrar em trabalho ulterior que, mesmo naquele ponto em que predominou o cruzamento luso-africano, como na Bahia, os caracteres antropológicos do índio se revelam a cada passo nos mestiços.

II. O modo por que estes diversos elementos antropológicos se ajustam e se combinam para formar a população brasileira é extremamente variável nas diversas zonas ou centros de população do país.

${ }^{2}$ Não há nos autores uniformidade nas denominações dadas ás diversas espécies de mestiços brasileiros.
Que devia ser assim, basta refletir: $1^{\circ}$ na desigualdade com que, nos tempos coloniais, a população branca foi distribuída pelo extenso território, em pequenos núcleos afastados e independentes uns dos outros; $2^{\circ}$ em que, tendo com a independência cessado quase completamente a imigração portuguesa, ao encetar-se de novo, já agora com os italianos e alemães, procurou ela de preferência certas regiões do país, com exclusão de outras; $3^{\circ}$ em que não só foi desigual a distribuição pelo país do negro importado com o tráfico, como também de um modo desigual foi o índio repelido ou destruído pelos invasores.

Assim, a princípio, os portugueses - raça branca pura - acharam-se em face do índio - raça vermelha pura -, mas quando o índio começou a recuar ante a invasão europeia, os invasores já não eram só portugueses, mas brancos e mamelucos.

A raça negra - que, embora dominada e como instrumento da raça branca, invadiu por sua vez o país e ajudou o branco a repelir o índio achou-se em face do branco, do índio e dos seus mestiços, e cruzou com todos. Mas evidentemente se em certos pontos ainda pude cruzar fácil e diretamente com o índio, em outros só o pode fazer com os brancos e os mamelucos, porque, há muito, o índio tinha fugido ou desaparecido.

Cessou primeiro a imigração portuguesa, os brancos ficaram em minoria em face dos negros importados com o tráfico e dos mestiços, que aumentavam pelo contínuo e incessante cruzamento.

Cessou, por sua vez, a imigração africana, toda em favor do mestiçamento, que continuava e continua a crescer.

\section{A situação atual é a seguinte.}

Em certos estados, todo o litoral do norte, da Bahia inclusive ao Pará exclusive, as raças puras ameaçam desaparecer ou diluir-se no mestiçamento. O índio fugiu ou extinguiu-se, os africanos não são mais importados, imigração europeia não existe.

Com certeza ainda há muito branco e muito negro, mas sempre em minoria em relação aos mestiços. E como o mestiçamento, mediato e imediato, continua em larga escala, como por outro lado nada limita ou circunscreve a reprodução das raças puras entre si, a consequência é que num futuro mais ou menos remoto se terão elas diluído de todo no cruzamento mestiço. 
Até não há muitos anos, não havia motivo para deixar de estender esta zona até São Paulo inclusive. No entanto, a grande corrente imigratória que despeja agora todos os anos, em São Paulo, Rio de Janeiro, Espírito Santo e Minas, um número avultado de brancos europeus, especialmente italianos e portugueses, tende evidentemente a tornar à composição étnica precedente, para a qual a imigração europeia é nula. E no cruzamento com o negro o mestiço luso-africano ali terá de deixar espaço ao cruzamento ítalo-africano.

No extremo sul, a imigração europeia - e aí figura preponderantemente o alemão -, junta a condições especiais da região, fez já predominar a raça branca, ou sob a forma de uma maioria de brancos crioulos não mesclados, ou de pardos com fraca dose de sangue africano e índio, recebido em adiantada diluição.

O Rio Grande do Sul é tipo desta região.

Do Rio Grande do Sul, escreveu o Dr. Sylvio Romero (Estudos de literatura contemporânea, Rio de Janeiro, 1885), o índio quase tem desaparecido, mas ali o branco predomina. A mestiçagem com o negro é escassa e com o índio ainda mais. Esta província será sempre uma exceção etimológica em nosso país.

No extremo norte - na Amazônia e nos estados do oeste -, o sangue africano, recebido já em diluição mestiça, vai diminuir em face do cruzamento do branco, ou dos mestiços com o índio, que predomina nesta região.

Pondo em balanço, a influência do negro e do índio, escreve ainda o mesmo autor, sou levado pelos fatos a dar a predominância aquele contra este. No Brasil, só as extremas terras das fronteiras é que abrem uma exceção. São as províncias pouco povoadas do alto do norte, onde o índio campeia ainda inútil e donde será expelido logo que o branco e o negro ali penetrem amplamente. É o caso do Amazonas, Mato Grosso, Paraná, e até certo ponto Goiás e Pará.

Admitindo, como admito, a população brasileira assim dividida em grupos étnicos distintos, consoantes com as proporções variáveis em que entraram em sua composição as três raças puras, afasto-me definitivamente do Dr. Sylvio Romero, a cujos importantes trabalhos na espécie devo ensinar-vos a render o devido e merecido preito.

Não acredito na unidade ou quase unidade étnica, presente ou futura, da população brasileira, admitida pelo Dr. Sylvio Romero: não acredito na futura extensão do mestiço luso-africano a todo o território do país: considero pouco provável que a raça branca consiga fazer predominar o seu tipo em toda a população brasileira.

Este ponto tem um valor particular na questão médico-legal que ora explano, como vereis em tempo. Merece, pois examinado a fundo.

Minha afirmação fora esta, escreveu o Dr. Sylvio Romero (Estudos de literatura contemporânea, Rio, 1885): no Brasil a maior parte da população é de mestiços; entre estes, no corpo colonizado de nosso solo, predomina a mestiçagem áfrico-lusitana, e é uma exceção apenas a região das fronteiras do alto norte e do extremo ocidente.

Atendendo ao incremento da imigração ítalo-germânica, escreveu mais recentemente (História da literatura brasileira, Rio de Janeiro, 1890):

Sabe-se que, na mestiçagem, a seleção natural ao cabo de algumas gerações, faz prevalecer o tipo raça mais numerosa, e entre nós, das raças puras a mais numerosa, pela imigração europeia, tem sido, e tende ainda mais a sê-lo, a branca. Os mananciais negros e caboclos estão estancados, ao passo que a imigração portuguesa perdura e a ela vieram juntar-se a italiana e a alemã. O futuro povo brasileiro será uma mescla áfrico-indiana e latino-germânica, provavelmente, se perdurar, como é provável, a imigração alemã.

O seu número (dos brancos) tende a aumentar, ao passo que os índios e os negros puros tendem a diminuir. Desaparecerão num futuro não muito remoto, consumidos na luta que lhes movem os outros, ou desfigurados pelo cruzamento. O mestiço, que é a genuína formação histórica brasileira, ficará só diante do branco puro, com o qual se há de, mais cedo ou mais tarde, confundir.

Ao passo que a descrição da população brasileira, dada nestas linhas pelo Dr. Sylvio Romero, refere-se claramente à primeira das nossas regiões, de fato as suas previsões só se poderiam realizar na segunda. E isto mostra ainda quão pouco uniforme etimologicamente é e será o Brasil.

Analisemos, pois, essas regiões uma a uma.

Na primeira região, a do litoral do norte da Bahia ao Maranhão, predomina realmente a mestiçagem luso-africana ligeiramente indígena: mais africana no sul, mais indígena no norte.

Aí o índio quase desapareceu de todo, e é possível que, num futuro muito remoto, os seus traços venham também a desaparecer da mestiçagem. 
Mas não vejo razão para se acreditar que o futuro há de pertencer aqui ao branco e não ao mulato.

Esta opinião do Dr. Sylvio Romero funda-se em duas suposições contestáveis e contrárias de todo o ponto a uma observação imparcial dos fatos.

A primeira é da persistência da imigração europeia para o norte; a segunda é a da futura extinção da raça negra nesta zona. O Dr. Sylvio Romero acredita na possibilidade da imigração europeia para o norte do Brasil, afirmando "que o clima do país é todo apto a colonização".

Mas é o próprio autor quem nos faz uma descrição vigorosa dos rigores e inclemências do clima brasileiro no norte e termina com estas considerações que menos relativa, de aclimamento para a raça branca:

Quem sabe até onde um dia chegará entre nós a ação do clima? Só os séculos futuros poderão dizê-lo. Esse influxo determina-se empiricamente pelos resultados contraditórios a que frações de uma mesma raça chegaram em regiões diversas. Que distância entre os arianos da Itália e da Grécia e os da índia. Aqui o calor produziu todos estes terríveis efeitos eloquentemente assinalados por H. Taine.

E acrescenta:

Eis aí a que ficou reduzida pelo clima da Índia a raça mais progressista e inteligente da Terra. Se o nosso elo não é tão déspota, não deixa de sê-lo também até certo ponto. Conjuremos sempre por novas levas de imigrantes europeus a extenuação do nosso povo: e conjuremo-la por meio de todos os grandes recursos da ciência.

Destes preceitos, conclui-se facilmente que o autor não confia na expansão demográfica da raça branca abandonada aos seus próprios recursos, propondo esse trabalho impossível da sua conservação por meios artificiais da ordem das estufas nos climas frios, ao lado de incessante renovação do sangue.

Ele afirma mais positivamente ainda: "O mestiço é a condição da vitoria do branco, fortificando-lhe o sangue para habilitá-lo aos rigores do nosso clima".

Ora, acaso a raça branca precisa desses recursos, carece do auxílio do mulato para adaptar-se, para desenvolver-se no sul da república?

É o Dr. Sylvio Romero quem responde:
Se o não fizerem (a distribuição dos imigrantes por igual), as três províncias do extremo sul terão em futuro não muito remoto, um tão grande excedente de população germânica, válida e poderosa, que a sua independência será inevitável.

Nestas condições acho difícil não reconhecer que a imigração branca, há muito extinta para o norte do Brasil, não tem grandes probabilidades de se restabelecer. E nisto vejo antes uma consequência natural das condições do país do que erros de administração possíveis de corrigir-se. Não se pode considerar imigração a entrada de um pequeno número de estrangeiros que procuram as principais cidades dos estados, em busca do nosso comércio.

Por outro lado, não descubro as causas da suposta extinção futura da raça negra no norte do Brasil.

Tomarei ao Dr. Sylvio Romero a declaração formal da sua perfeita adaptação ao nosso clima.

O negro, diz ele (loc. cit.), é adaptável ao meio americano; é susceptível de aprender; não tem as desconfianças do índio; pode viver ao lado do branco, aliar-se a ele. Temos hoje muitos pretos que sabem ler e escrever: alguns formados em direito, em medicina, ou engenharia; alguns comerciantes e ricaços; outros jornalistas e oradores. Ao negro devemos muito mais do que ao índio; ele entra em larga parte em todas as manifestações de nossa atividade. Cruzou muito mais com o branco.

É ainda o Dr. Sylvio Romero quem nos ensina, até certo ponto de acordo com Orgeas, que em contacto com o branco, o negro não se civiliza, mas também não se extingue.

É sabido, diz ele, que os povos selvagens postos em relação com raças civilizadas, ou civilizam-se, o que é raro, ou extinguem-se, o que é a regra geral. O negro tem desmentido a lei histórica!

É exato que os numerosos milhões de africanos introduzidos pelo tráfico sofreram uma redução extraordinária. Mas não foi isso obra do clima, ou de uma incapacidade de adaptação, mas tão somente efeitos da escravidão. "As pestes e as guerras fizeram aos índios, disse o autor com muita razão, o que os trabalhos forçados fizeram aos africanos".

Mas a escravidão desapareceu do Brasil. 
Temos, pois, que nesta primeira região, das duas raças puras ainda existentes - e que parecem entregues definitivamente à sua sorte sem poder contar muito com o auxílio de novas imigrações - uma, a negra, é perfeitamente adaptável; a outra, a branca, é de uma adaptação mais difícil.

Ora, como nestas condições a raça que tende a predominar é a mais adaptável, o receio deve ser que a reversão à raça pura não seja em favor da raça negra. E, na melhor hipótese, quando se queira contar em favor mais que se pode esperar é que ela venha a da raça branca a sua civilização superior, o cruzar largamente com o negro, dando os mestiços estáveis em que o Dr. Sylvio Romero vê a condição da resistência da raça branca aos rigores do nosso clima.

Este mestiço será forçosamente o mulato, ou quando muito o pardo com uma dose mínima do sangue indígena.

Toda diferente é a condição das duas zonas seguintes, a do centro São Paulo, Minas, Rio de Janeiro - e a do extremo sul.

Comparando-se o norte e o sul do país, nota-se já um certo desequilíbrio que vai tendo consequências econômicas e políticas: ao passo que o norte há sido erroneamente afastado da imigração, vai esta superabundando no sul, introduzindo os novos elementos italianos e alemão -, fato que vai cavando entre as duas grandes regiões do país um valor profundo, já de si preparado pela diferença dos climas.

Aqui são de todo ponto justas e razoáveis as previsões de um predomínio futuro da raça branca, embora ligeiramente mesclada, não só porque a imigração está-lhe dando o predomínio numérico, como porque aqui o branco não precisa do negro para se aclimar.

A distinção etnológica que estabeleço entre as duas regiões do sul procura o seu fundamento natural em que, no extremo sul, o elemento negro é muito insignificante e predomina o elemento germânico; no centro, o negro é numeroso e predomina a imigração ítalo-portuguesa.

Julgo inadmissível igualmente que a população da nossa quarta e última região - Amazônia e estados ocidentais - possa vir a ter uma composição étnica igual a qualquer das precedentes, assim como que a eliminação do índio venha a se fazer aí em favor do mestiço luso-africano.
O negro é muito mais raro no Amazonas do que o supunha o Dr. Sylvio Romero. Afirma uma competência indiscutível, o Sr. José Veríssimo.

Ao influxo destas duas principais variedades (tapuio e caboclo), que em rigor raças não são, escrevia este autor em 1885 (Cenas da vida amazônica, Lisboa, 1887), sujeitaram-se sem relutância, nem exceção, os demais mestiços não só da mesma origem, como de proveniência africana (mulatos, cafuzos e suas variedades). Na pouca importância numérica do elemento negro na Amazônia está a razão disto. Esta região, com efeito, foi das menos povoadas por negros, e hoje é raríssimo encontrar africanos nas duas províncias, principalmente fora das capitais. Em uma população de cerca de quinhentos mil habitantes não havia mais de vinte e oito mil escravos, o que, relativamente a outras províncias do Brasil, é pouco. Porém, entre esses escravos mesmo encontra-se um crescido número de mestiços da raça indígena, como os cafuzos e os impropriamente chamados curibocas, e até tipos claros a ponto de se confundirem com os mamelucos, o que se pode explicar por cruzamentos deste tipo com mestiços de origem africana, onde ele predominou ou em que se deu o atavismo do branco Do estudo da língua, das crenças e das tradições populares aqui, ressalta em toda a evidência inferioridade desse elemento e a supremacia das raças indígenas.

Isto tudo prova, parece-me, que o elemento que nos veio escravizado da África, o qual tanto concorreu para o nosso progresso material e para a nossa degradação moral, foi suplantado no vale do Amazonas pelo indígena, cuja língua aqui levou de muito a melhor na luta que travou com a dele, o que não aconteceu sempre no sul, não só com deste, como com a portuguesa, obrigada a aceitar em boa copia materiais africanos. Lá também esta influência é sensível sobre as crenças vulgares e os costumes, o que se não dá na Amazônia, onde todas as feições do espírito popular ressentem-se da influição indigna mais porventura (tendo em conta sempre a relatividade das coisas) do que da portuguesa.

Não quero fechar este capítulo sem notar - e isto ajudará talvez a explicar a insignificância apontada do elemento africano -, que entre estes e seus descendentes e os daqueles existe, se não ódio, ao menos uma animosidade para a qual não pude até agora achar explicação satisfatória.

Não será, portanto, o branco quem há de provavelmente desalojar o índio, porque o clima que já impede a imigração europeia para o norte, não deixará de fazê-lo para o Pará e o Amazonas. 
Também não será o negro, porque não só está estancada a fonte da imigração africana, mas os negros, que possuímos, acham-se localizados e em pleno mestiçamento.

Provavelmente à população mestiça está reservada a missão de levar consigo, na sua lenta expansão demográfica, a civilização e a cultura europeia ao extremo norte e ao oeste.

Este fato já está em via de realização no Pará e Amazonas, para onde se tem encaminhado forte corrente emigratória dos estados vizinhos, Ceará, Piauí e Maranhão.

Daí há de provir naturalmente uma integração mais vasta do elemento indígena naquela população mestiça, graças à facilidade maior, denunciada pelo Cons. Araripe, do cruzamento entre índios e os mulatos e pardos.

Não sei se disso nos provirá algum bem. Em todo o caso, não convêm esquecer a observação do Dr. Sylvio Romero, de que as nações americanas menos progressistas são exatamente aquelas em que não predominou o elemento europeu, e que, a julgar pela descrição do Sr. José Veríssimo, é bem pouco prometedor o futuro do cruzamento indígena na Amazônia.

Prevejo que se possam arguir duas principais objeções à divisão etimológica do Brasil, que adotei e expus nesta conferência. Primeiro, que mesmo nas zonas descritas não existe uniformidade étnica; segundo, que seja esse apenas o aspecto atual, e todo de ocasião, do país, sem probabilidades de uma confirmação futura.

Não posso, nem me proponho a contestar em absoluto uma e outra objeção, pois que elas em nada prejudicam as conclusões que pretendo tirar da divisão exposta.

Todavia, em relação à primeira, farei notar que devia ser assim mesmo, pois o que eu pretendo é que nas suas linhas gerais, nos seus grandes traços, essas divisões regionais, como composição étnica, opõem-se umas às outras e parecem dispor de elementos que no futuro mais afirmem e acentuem a sua distinção. Daí não se deveria concluir que não possa existir, aqui na Bahia, por exemplo, uma vila, Olivença, que, pelo predomínio da população indígena, poderia bem figurar ao lado de qualquer vila paraense.
III. Quanto à segunda, posso redarguir que a mais poderosa de todas as garantias dessa futura distinção está principalmente na conformação física geral do país e na sua climatologia.

Prefiro tomar aos diversos trabalhos do Dr. Sylvio Romero, manifestamente infenso ao meu modo de sentir, os dados em que o fundamento.

O corpo do Brasil, diz este ilustre escritor (História da literatura etc.), forma uma espécie de vasto triângulo irregular, compreendendo zonas diversas, com duas grandes bacias hidrográficas: a do Amazonas e a do Paraná, com inúmeros afluentes, que, com outras bacias secundárias, cortam o país de norte a sul, ou de oeste a leste. A zona quente admite uma divisão geral: a) as terras mais ou menos pantanosas das costas, as do grande vale do Amazonas e do Paraguai, onde reinam as moléstias hepáticas e as febres palustres; b) a região sertaneja, compreendendo todo o interior norte do país, o teatro das secas. A região fresca também sofre uma divisão: 1) as três províncias meridionais, onde vagueia o minuano frio e ríspido; 2) as terras altas das províncias intermédias, São Paulo, Rio de Janeiro e Minas, região que não tem o calor e a uberdade do norte, nem a esterilidade relativa dos terrenos do extremo sul.

É fácil um cotejo demonstrativo das relações que guardam entre si as divisões regionais que estabeleci, do ponto de vista étnico, e as que resultam desta descrição física do Brasil. Mais de acordo, porém, está porventura a divisão climatológica.

O Brasil oferece nada menos de duas zonas climáticas diferentes - a quente que se estende da sua fronteira norte até o trópico de Capricórnio, e a fresca que compreende as terras ao sul do trópico, a que se podem ligar os terrenos altos das províncias imediatamente próximas. É um erro grosseiro confundir cousas tão distintas. É certo que a maior parte do país, o verdadeiro Brasil, está contido na zona tórrida, que encerra quase todas as terras baixas do litoral, de um clima quente e úmido, e as altas dos sertões do norte, de clima quente e seco, desde a fronteira septentrional até a província de São Paulo. Uma parte desta última, e as três províncias meridionais - Paraná, Santa Catarina, Rio Grande do Sul - ficam além do trópico e gozam de clima suave. Sabe-se que a Serra do Mar nestas últimas regiões aproxima se do litoral, oferecendo para o interior uma vasta lombada de terras altas de um clima quase europeu. Além disto, as terras elevadas dos platôs do Rio de Janeiro, São Paulo e Minas, se não tem 
a frescura das regiões meridionais, não se podem confundir com as terras quentes do centro e do litoral do norte. Constituem um clima temperado e ameno.

O Sr. Araripe Junior já em tempo sustentou a existência de uma diversidade étnica nas antigas províncias do império. Aqui, porém, nem a questão é encarada pelo mesmo prisma, nem resolvida pelo mesmo modo.

\section{CAPÍtulo V}

\section{A POPUlAÇ̃̃o BRASILEIRA NO PONTO DE VISTA DA PSICOLOGIA CRIMINAL - ÍNDIOS E NEGROS}

Sumário - O problema da responsabilidade penal das raças inferiores no Brasil; distinções que exige. O índio americano, sua incapacidade de civilização. O negro africano na América; suas condições sociais; fator essencial da sua criminalidade. Condições de responsabilidade antenada ainda na melhor hipótese.

I. Discriminados assim os elementos antropológicos distintos em que naturalmente se resolve a população brasileira, posso abordar agora a questão capital que nos ocupa.

Por si mesmo, ela se formula nos seguintes quesitos:

Pode-se exigir que todas estas raças distintas respondam por seus atos perante a lei com igual plenitude de responsabilidade penal? Acaso, no célebre postulado da escola clássica e mesmo abstraindo do livre arbítrio incondicional dos metafísicos, se pode admitir que os selvagens americanos e os negros africanos, bem como os seus mestiços, já tenham adquirido o desenvolvimento físico e a soma de faculdades psíquicas, suficientes para reconhecer, num caso dado, o valor legal do seu ato (discernimento) e para se decidir livremente a cometê-lo ou não (livre arbítrio)? - Por ventura pode-se conceder que a consciência do direito e do dever que tem essas raças inferiores, seja a mesma que possui a raça branca civilizada? - ou que, pela simples convivência e submissão, possam aquelas adquirir, de um momento para o outro, essa consciência, a ponto de se adotar para elas conceito de responsabilidade penal idêntico ao dos italianos, a quem fomos copiar o nosso código?

Responder alguém a estas inquirições pela afirmativa seria empenhar em sério compromisso o bom conceito dos seus conhecimentos em ciências biológicas. A resposta exige distinções importantes e capitães. 
Não creio haja ainda hoje espírito culto e esclarecido que ouse afirmar a responsabilidade penal, como a entende e requer o nosso código, no caso de uma ação nociva cometida por índio completamente selvagem, ou por um negro africano, tomado às suas hordas e transportado de repente ao nosso país, como foram durante o tráfico. E Tarde tem toda razão. O proceder e o sentimento da massa da nossa população para com os índios selvagens - hoje como nos tempos coloniais - são argumentos valiosos que ele poderia invocar em favor da sua teoria da identidade social, que aliás nem por isso me seduziria mais.

Da bula de Paulo III - que precisou declarar oficialmente aos espanhóis, ao contrário do que supunham, serem os índios americanos homens como eles -, até os nossos dias, o senso moral poluísse bastante, e até com exagero às vezes, nas classes dirigentes e cultas, para que os sentimentos de piedade e simpatia as levassem a considerar ou pregar a igualdade cristã, isto é, humana, e até social do índio. E os nossos legisladores que, em matéria de conhecimentos biológicos e sociológicos, não iam muito além do ensino religioso, influenciados por ele transportaram para os códigos este princípio de igualdade, que, do ponto de vista do livre arbítrio, devia ser tão injusto nos, domínios penais, quanto, nos domínios sociais, era fecunda em consequências civilizadoras a bula de Paulo III.

Para o índio domesticado, para o negro submetido à escravidão, a questão é mais complexa. A resposta depende de saber se a domesticação do índio e a submissão do negro são capazes de transformá-los completamente em um homem civilizado.

Nas primeiras gerações, a solução é ainda pouco duvidosa.

Um índio selvagem aprisionado e domesticado, um negro africano reduzido à escravidão, não terão, pelo simples fato da convivência com a raça branca, mudado de natureza.

Então eles se poderão conter pelo temor do castigo e receio de violências, mas absolutamente não terão consciência de que seus atos possam implicar a violação de um dever ou o exercício de um direito, diversos daquilo que até então era para eles direito e dever.

A dificuldade real está toda em avaliar a responsabilidade do índio e do negro já incorporados à nossa sociedade, gozando dos mesmos direitos e colaborando conosco na civilização do país.
II. A impossibilidade da civilização e cultura do brasílio-guarany, mesmo em demorado contacto com a raça branca, é uma questão julgada no Brasil.

A catequese, melhor a domesticação do índio, não é, não pode ser considerada civilização; não importa de modo algum o aperfeiçoamento social, ao contrário conduz à degradação do selvagem.

É este o sentir do próprio Dr. Couto de Magalhães, o entusiasta partidário da catequese por intérpretes.

O índio catequizado, diz ele, é um homem degradado, sem costumes originais, indiferente a tudo, e, portanto à sua mulher e quase que à sua família.

Cada tribo que nós aldeiamos, acrescenta ainda, é uma tribo que degradamos, e a que por fim destruímos com as melhores intenções e gastando nosso dinheiro.

Depois de uma descrição magistral do estado miserando de decadência moral a que chegaram os índios civilizados, o Sr. José Veríssimo, apreciando a capacidade de civilização do índio e referindo-se às citações do Dr. Couto de Magalhães acima transcritas, assim se pronuncia:

A não ser o aldeamento, aí condenado, julgamos inexequível qualquer tentativa de catequese e civilização do selvagem. Só os cruzamentos com as condições que acima indicamos serão capazes, não de civilizar, no sentido absoluto desta palavra, mas de tornar nos úteis as raças selvagens. Por isso pensamos que o que há a fazer, se essa medida for impossível, é olvidá-las nas solidões das florestas em que vivem, embora sintamos profundamente que a evidência dos fatos nos obrigue a pensar assim.

É opinião nossa que a catequese, por si só, é impotente para civilizar o selvagem. Por maior que seja a força da civilização, ela nunca se imporá a um selvagem pelo único contato de um homem, por mais autorizada e eloquente que seja a sua voz e atraente a sua doutrina. Conquanto a perfectibilidade humana seja um dogma que aceitamos e proclamamos, não cremos que a barbárie de séculos, a barbárie tradicional, possa ser substituída pela civilização, em um dia, em um ano, em anos mesmo e longos até, nem pelo missionário, nem pelo intérprete, nem pela colônia militar.

De fato, o índio não se incorporou à nossa população, nem colabora conosco senão sob a forma de mestiços. A propósito da Exposição 
Anthropologica Brasileira, de 1881, o Sr. Sylvio Romero fazia a justa observação de que, para que nela pudesse figurar a raça americana, foi mister mandar vir de amostra do Rio Doce alguns índios aldeiados, visto ser quase impossível encontrados na população fluminense.

Há mais de quatro anos que estudo a população baiana da capital, e agora, de momento, só me lembro de dois índios nesta cidade, a criada de uma família de meu conhecimento e um homem muito visto entre nós como carregador de móveis.

Tanto é verdade que no Brasil o índio extinguiu-se, ou está em via de extinção completa, mas não se civilizou.

III. Do negro, os interesses inconfessáveis da escravidão e as lutas incandescentes do abolicionismo tornaram os juízos mais contraditórios.

Morei, o eminente autor do Traité des dégénerescences physiques, intellectuettes et morales de Vespece humaine (Paris, 1857), subscreveu a opinião de Buffon,

que os negros crioulos, qualquer que seja a nação de que tirem a sua origem, não conservam dos seus pais e mais senão o espírito de sujeição e a cor; que são mais engenhosos, mais racionáveis, mais astutos, porém mais libertinos e madraços do que os vindos d'África.

Morei, que acreditava na possibilidade da civilização e conversão religiosa do negro, considera a degeneração do crioulo um efeito da educação moral que lhe dispensava o branco, e particularmente um efeito da escravidão.

Orgeas (La pathologie des races humaines, Paris, 1886) discorda desta opinião. Para ele os caracteres das raças são simples manifestações da sua adaptação ao habitat especial em que são obrigadas a viver. Para o negro, a sua organização é a condição da adaptação humana aos climas quentes. E essa organização - como o testemunham a África de todos os tempos e o Haiti de hoje -, não é compatível com a civilização das raças brancas.

Num artigo de polêmica, escreveu o Dr. Sylvio Romero (A emancipação dos escravos; Revista Brasileira, 1881):

Não há exemplo de uma civilização negra. A única civilização africana, a do Egito, era branca, do ramo cuschitosemita, e ainda hoje nos baixos relevos e antigas pinturas egípcias se nos deparam, ao lado dos belos tipos brancos, os seus escravos negros com a mesma fisionomia dos atuais pretos do Darfur... A África esteve desde a mais remota antiguidade em contacto com os egípcios, persas, gregos, romanos, fenícios, cários e árabes, e o negro nunca chegou a civilizar-se! Há quatro séculos está em contacto com os modernos povos europeus e continua nas trevas.

E, a propósito desta inferioridade cultural do negro, cita uma passagem do naturalista Huxley, relativa à emancipação na América do Norte, da qual convém destacar alguns trechos.

Pode ser absolutamente certo, diz Huxley, que alguns negros sejam superiores a alguns brancos; mas nenhum homem de bom senso, bem esclarecido sobre os fatos, poderá crer que em geral o negro valha tanto quanto o branco e muito menos seja-lhe superior. E se assim é, torna-se impossível acreditar que logo que sejam afastadas todas as incapacidades civis, desde que a carreira lhes seja aberta e que não sejam nem oprimidos nem favorecidos, nossos irmãos prognáticos possam lutar com vantagem com os seus irmãos melhor favorecidos de cérebro. Não só os irmãos negros não poderão, pois, chegar aos mais altos lugares da hierarquia estabelecida pela civilização, ainda que não seja necessário confiná-los lá para a última classe.

Se não se conhece, escreveu o Dr. Sylvio Romero (História da literatura, etc.), um só negro, genuinamente negro, livre de mescla, notável em nossa história, conhecem-se muitos mestiços que figuram entre os nossos primeiros homens.

Esta questão - da capacidade de civilização da raça negra -, foi magistralmente estudada e interpretada, com o rigor científico e a isenção de ânimo que requeria, principalmente pelo Sr. Abel Havelacque (Les negres de l'Afrique souséquatoriale, Paris, 1889), cujas conclusões, na impossibilidade de transcrever a obra, para aqui trasladarei.

Será necessário declarar agora, que, traçando este esboço etnográfico, não fomos nem detrator sistemático, nem amigo cego do irmão negro? Que, por seu desenvolvimento intelectual e por sua civilização, os negros africanos sejam inferiores à massa das populações europeias, ninguém evidentemente pode pôr em dúvida. Ninguém pode duvidar tampouco de que anatomicamente o negro esteja menos adiantado em evolução do que o branco. Os negros africanos são o que são: nem melhores nem piores que os brancos; simplesmente eles pertencem uma outra fase do desenvolvimento intelectual e moral. Essas 
populações infantis não puderam chegar a uma mentalidade muito adiantada e para esta lentidão de evolução tem havido causas complexas. Entre essas causas, umas podem ser procuradas na organização mesma das raças negríticas, as outras podem sê-lo na natureza do habitat onde essas raças estão confinadas. Entre tanto, o que se pode garantir com experiência adquirida, é que pretender impor a um povo negro a civilização europeia é uma pura aberração.

Um negro disse um dia a viajantes brancos, que a civilização branca era boa para os brancos, má para os negros. Não há sentença mais sensata. É impossível negá-lo: até onde penetraram as missões cristãs, tanto as protestantes como as católicas, elas não fizeram mais do que levar a hipocrisia e um requinte de depravação. Quer isto dizer que o destino do negro africano deve nos deixar indiferentes, e que não devemos pensar em fazê-lo beneficiar dos nossos progressos? De modo algum. Trata-se, ao menos, de poupar a aguardente do tráfico, as missões religiosas e o espingardeamento a uma criança grande, crédula e inconstante, da qual, parece, não convirá, por muito tempo, exigir as qualidades de homem feito.

Mesmo entre os ardentes partidários do abolicionismo houve exemplo de espíritos capazes de julgar esta questão toda científica, com inteira isenção de ânimo, e sem o sentimentalismo fátuo e pretensioso que entre nós para muita gente disputa ainda as honras de última ratio. Numa obra de fôlego (A escravidão, o clero e o abolicionismo, Bahia, 1887), escreveu o Dr. Anselmo da Fonseca, meu distinto colega nesta faculdade:

A raça africana tem um defeito e um crime. O defeito é estar ainda atrasada no desenvolvimento da civilização e em um período em que já esteve a raça branca, que foi outrora canibal, como ainda hoje o são muitas tribos africanas e americanas, e que também já ignorou todas as artes, viveu sem leis e suportou o cativeiro.

Uma justa aplicação destes princípios nos explica as condições de atividade dos negros americanos. Podemos ceder a palavra ao Dr. Corre (Le crime en pays créoles, Paris, 1889), cuja competência na matéria não se poderá legitimamente contestar. Tem se pretendido, diz ele, que o negro americano difere muito do seu antepassado, o negro africano; que perdeu até os caracteres físicos deste, e que assimilou os caracteres intelectuais do branco. Não hesito em declarar que são puras mentiras ou puras quimeras emitidas por observadores de gabinete. O negro crioulo libertou-se dos labores embrutecedores e das misérias degradantes do seu congênere africano, adquiriu algum verniz pelo atrito com elementos étnicos superiores; melhorou, mas não deixou de pertencer à sua raça, não é adaptável às mesmas condições sociais do ariano. Se quiser um prova, lancem-se as vistas sobre a república do Haiti. Houve um Toussaint Louverture, e em torno dele, após ele, um pequeno número de negros (rari nantes), que mostram qualidades eminentes: quem folhear a história dos povos selvagens mais aviltados, também encontrará nela tipos verdadeiramente superiores. Mas exceções numa raça não poderiam estabelecer a capacidade real da massa a se elevar sequer ao nível médio das sociedades melhor organizadas... A independência de S. Domingos serve ao menos para mostrar o que vale o negro abandonado às suas próprias forças, e a lição é cheia de ensinamentos para todos aqueles a quem não cega o espírito de partido. Nos países regidos segundo as fórmulas das civilizações europeias, os negros conservam-se negativos ou atrasados, sempre em eminência de conflito. Não sentem e não compreendem a modo dos arianos, assim como anatomicamente não são constituídos a modo deles. Não podem absorver, assimilar, senão uma certa porção da ração soi disant regeneradora que se lhes oferece generosa... e ineptamente: o resto é muito indigesto para eles e provoca reações, que multiplicam o delito e o crime. O negro crioulo tem escolas por toda parte: ele as frequenta com uma emulação louvável, porque ouviu repetir que a instrução abria as portas às carreiras mais honrosas e tinha valido aos brancos a sua supremacia; mas assim que sabem ler, escrever e contar um pouco, creem-se um homem superior e bem armado para ambicionar as funções mais difíceis... E mais próprias a lançar sobre eles algum brilho... O negro não tem mau caráter, mas somente caráter instável como a criança, e como na criança - mas com esta diferença que ele já atingiu a maturidade do seu desenvolvimento fisiológico -, a sua instabilidade é a consequência de uma celebração incompleta. Num meio de civilização adiantada, onde possui inteira liberdade de proceder, ele destoa... como eram nossos países d'Europa, essas naturezas abruptas, retardatárias, que formam o grosso contingente do delito e do crime. As suas impulsividades são tanto melhor e mais frequentemente frequentadas para o ato antissocial, quanto às obrigações da coletividade lhes aparecem mais vagas, quanto elas são, em uma palavra, menos adaptáveis às condições de sua moralidade e do seu psíquico. O negro crioulo conservou vivaz os instintos brutais do africano: é rixoso, violento nas suas impulsões sexuais, muito dado à embriaguez e esse fundo de caráter imprime o seu cunho na criminalidade colonial atual. 
IV. A presunção lógica, por conseguinte, é que a responsabilidade penal, fundada na liberdade do querer, das raças inferiores, não pode ser equiparada a das raças brancas civilizadas.

No entanto, o problema não deve ser resolvido em termos gerais de raça, e exige ao contrário que se desça à apreciação e ao exame das individualidades.

Ora, se admitem todos que essas raças não estão aptas ainda para um alto grau de civilização, todavia ninguém desconhece que há negros e pode haver índios que valham mais do que brancos.

Para estes negros e índios pelo menos, que serão a exceção, embora uma exceção pouco numerosa, a responsabilidade penal deveria ser completa.

Mas, mesmo nestes casos da melhor hipótese, suponhamos a perpetração de um crime. E no crime, como muito bem diz Ferri, há sempre um compromisso do estado normal.

Para logo surgirá à dúvida muito bem fundada, o problema imperioso de saber: se o conflito, que a imposição, mais ou menos violenta, de uma civilização superior, criou entre os sentimentos morais novos, superficiais e ainda não completamente radicados de um lado, e os instintos antigos, cimentados e estratificados pela herança de uma longa cadeira de antepassados, de outro lado, é ou não de ordem a perturbar tão profundamente o mecanismo da determinação voluntária, de modo a dar ganho de causa e predomínio às impulsões instintivas e indomáveis criminosas no novo meio -, mas completamente inimputáveis.

O mouro, que uma explosão de ciúmes, violenta e tempestuosa, requeria em Otelo, não é mais do que o eloquente atestado dos conhecimentos psicológicos de Shakespeare. Posta a questão nestes termos, é fora de dúvida que mesmo nessas condições excepcionais, a psiquiatria moderna, chamada a se pronunciar sobre o grau de responsabilidade dos nossos criminosos, negros e índios, acabaria naturalmente, na grande maioria dos casos, por lavrar um veredictum de irresponsabilidade em favor deles.

E não seria isso efeito de preocupações doutrinarias, mas tão somente dedução, a mais lógica e rigorosa dos falsos princípios psicológicos em que a escola clássica havia feito repousar a doutrina da responsabilidade penal.

Belíssimo espécime de um julgamento de irresponsabilidade por defeito de educação (e salientarei bem que não se tratava de civilização ou domesticação de selvagens), em pessoa de mente perfeitamente sã, temos nós em luminoso parecer de segura análise psicológica, firmado pelo egrégio alienista Motet e o sábio professor Brouardel, insuspeitos ambos por títulos numerosos de comprovado critério e moderação, da acusação de irrefletidos ou apaixonados em matéria doutrinaria.

\section{Expõem eles:}

$\mathrm{O}$ ato criminoso pelo qual $\mathrm{X}$ é processado, é sem precedente e contrasta violentamente com um passado dos mais honestos, dos mais laboriosos, em que as dificuldades da existência, a luta pela vida, foram corajosamente suportadas. Ele permaneceria inexplicável, se X..., num exame a que se prestou voluntariamente, não tivesse feito a sua autobiografia: pudemos segui-lo assim desde a infância, através da mocidade e maturidade, e formamos um juízo das disposições de um espírito, singular talvez por certos lados, mas de uma espécie que não é nem comum nem vulgar.

Os estudos deste gênero conduzem, de ordinário, à procura e à determinação de perturbações psíquicas e intelectuais. $\mathrm{O}$ ato incriminado, pelas circunstâncias estranhas em que se tem produzido, supõe as mais das vezes a moléstia, a loucura; querer se trate de estados transitórios ou de estados duradouros, é sempre possível demonstrar a impulsão patológica e reduzir o fato a suas proporções verdadeiras.

Aqui as condições são completamente outras; não há estado patológico, e nós temos que fazer a análise médica-psicológica de um caráter, que seguir uma curiosa evolução num homem transviado em um meio, para viver no qual nada o tinha suficientemente preparado.

E depois de notável estudo, que é um modelo de sagacidade e mestria, concluem os dois sábios:

Tudo o que temos dito dele (o criminoso), após longo e severo estudo, nos permite pôr em relevo a influência de causas sociais sobre determinações que nem por isso são menos culposas, como esta diferença que o homem que foi submetido ao nosso exame exatamente por causa das circunstâncias em que viveu, se desenvolveu, do meio em que as suas ideias se formaram, não tendo por contrapeso uma educação, uma instrução primaria suficientes -, não pertence a um tipo normal.

Não temos o direito de ir mais longe do que vai ele próprio, reconhecendo-se culpado perante a lei; mas temos o dever de consignar as imperfeições do seu desenvolvimento intelectual e 
afirmar que há lugar de levá-las em conta na apreciação da sua responsabilidade no ponto de vista penal.

É o criminoso, de tentativa de homicídio, não foi julgado culpado.

Mas, quem não vê que essas condições se realizam todos os dias entre nós, com ou sem consciência dos protagonistas? Que nem delas se apercebem - aliás, também é verdade -, os que julgam os criminosos segundo o grau da sua imputabilidade moral, e nem delas curou o legislador que entendeu dever a repressão dos crimes ser função da liberdade da vontade, e ser lícito ainda por cima prescindir, abstrair sem contradição, da desigualdade biológica e social com que a natureza marcou os diferentes graus da evolução dos povos?

O desequilíbrio, a perturbação psíquica provocada por uma adaptação imposta e forçada de espíritos ainda tão atrasados a uma civilização superior; a solicitação do grande esforço mental, exigido pela atual luta pela existência social, com certeza hão de criar entre nós nas raças inferiores, vestidas de um momento para o outro a povos civilizados, tipos muito menos normais do que era o do caso dos Drs. Motet e Brouardel.

Basta refletir um instante em que só os africanos e os índios conservam mais ou menos alterados, do novo meio social, os seus usos e costumes, como ainda em que fazem destes com os novos um amálgama indissolúvel, para se prever que nas suas ações hão de influir poderosamente as reminiscências, conscientes ou inconscientes, da vida selvagem de ontem, muito mal contrabalançadas ainda pelas novas aquisições emocionais da civilização que lhes foi imposta.

A demonstração, melhor a exemplificação, não seria tarefa árdua e muito menos impossível.

Particularmente em matéria de crenças religiosas muito há de observar e respigar na nossa população. A digressão agora comprometeria, porém, a dedução da minha tese. Reservo-o por isso para estudos ulteriores.

No entanto, o exame que tenho feito me autoriza plenamente, parece, a concluir que os negros e índios, de todo irresponsáveis em estado selvagem, têm direitos incontestáveis a uma responsabilidade atenuada.

\section{CAPÍtULO VI}

\section{A POPULAÇÃo BRASILEIRA NO PONTO DE VISTA DA PSICOLOGIA CRIMINAL - OS MESTIÇOS}

Sumário - Condição mental dos mestiços: influência degenerativa do cruzamento entre raças muito dessemelhantes. As raças cruzadas da Amazônia: causas da degradação. Transmissão hereditária aos mestiços do estado emocional dos selvagens: impulsividade e imprevidência, suas consequências psicológicas. A apatia não exclui a impulsividade. O caráter excepcional da degradação dos mestiços da Amazônia. O mestiçamento em todo o Brasil; os mulatos. O preconceito de cor e os crimes de raça no Brasil; sua interpretação natural. A transmissão hereditária dos caracteres étnicos aos mestiços; atavismo e puberdade, sua importância médico-legal. Conclusões.

I. Sem preterição manifesta das regras mais elementares de uma dedução lógica rigorosa, torna-se impossível não prosseguir nesta análise, fazendo as suas conclusões extensivas aos casos de mestiçamento.

O conflito - que se estabelece no seio do organismo social pela tendência a fazer, à força, iguais perante a lei e seus efeitos, raças realmente tão distintas e desiguais -, tem o seu símile e se deve realizar no seio do organismo individual, nos casos de mestiçamento em um mesmo indivíduo qualidades físicas, fisiológicas e psíquicas, não só distintas, mas ainda de valor muito diferente no ponto de vista do conceito evolutivo do aperfeiçoamento humano.

É verdade biológica bem conhecida que nos cruzamentos de espécies diferentes o êxito é tanto menos favorável quanto mais afastada na hierarquia zoológica estão entre si as espécies que se cruzam.

Nestes casos o cruzamento acaba sempre por dar nascimento a produtos evidentemente anormais, impróprios para a reprodução e representando na esterilidade de que são feridos, estreitas analogias com a esterilidade terminal da degeneração psíquica. 
Tem se afirmado, é exato, que o cruzamento das raças ou espécies humanas não resulta em híbridos.

Mas os fatos demonstram que se ainda não está provada a hibridez física, certos cruzamentos dão origem em todo caso a produtos morais e sociais, evidentemente inviáveis e certamente híbridos.

Qual é o efeito da mistura das raças sobre a natureza mental, inquire Spencer (Essais scientifiques, Paris, 1879), como um dos grandes problemas da psicologia comparada da humanidade? Em todo o reino animal, temos motivo para crê-lo, todo cruzamento entre variedades que se tem tornado muito estranhas uma da outra, no físico nada produz que preste; ao contrário, a união entre variedades ligeiramente diferentes do físico dá bons resultados. Dá-se o mesmo para a natureza mental? A julgar por certos fatos, a mistura entre raças de homens muito dessemelhantes parece produzir um tipo mental sem valor, que não serve nem para o modo de viver da raça superior, nem para o da raça inferior, que não presta enfim para gênero algum de vida. Ao contrário, povos da mesma origem, que, tendo vivido durante muitas gerações em circunstâncias diferentes, se tem ligeiramente afastado um do outro, dão, se vê às vezes, pelo cruzamento, um tipo mental superior a certos respeitos.

O mestiçamento no Brasil confirma e exemplifica estas previsões.

II. O Sr. José Veríssimo, observador, tão sagaz quanto competente, descreve nestes termos a população mestiça da Amazônia.

Daquela raça selvagem (o índio) inferior, perseguida e aviltada pela escravidão e pelo desmembramento de sua rudimentar família, e destas outra (portugueses) civilizada, superior, porém mal educada e representada talvez pelo que tinha de pior, provieram o tapuio e o mameluco, um coagido a viver uma vida artificialmente civilizada e cruzando-se, ou antes mestiçando-se, se assim posso dizer, pela ação dos meios; o outro, seu filho verdadeiro, com todos os defeitos de ambas, e quiçá sem algumas das boas qualidades de nenhuma... A feição dominante do caráter desta gente é uma falta completa, absoluta, de energia e de ação. Todos os seus defeitos decorrem deste e neste se podem resumir.

Filhos de uma raça para quem nada eram as privações dos gozos materiais, são sem eles como seus pais. Suas mesquinhas habitações são sem elegância e sem conforto. $\mathrm{O}$ ar entra-lhe parcamente, que a casa é baixa e as janelas poucas. Falecem-lhes aspirações de um melhor viver. Se o chefe da família vai à pesca e traz bom pescado, se $o$ ano foi farto e a mandioca abundante, enfim se eles têm alimento, ou segundo a sua expressão, mantimento, por algum tempo, as flechas, os anzóis, os arpões do pescador adormecem a um canto juntos da enxada e do terçado que serviram para o mofino cultivo da maniva, da cana ou do tabaco, até que acabem as provisões e que haja mister refazê-las. Tudo o que exige ação, iniciativa, exercício continuado, persistência, a energia moral por onde as fortes individualidades se afirmam, lhes é impossível. Tal é o seu estado moral... A casa revela a constituição da família que a habita. No exterior, como no recinto desta, despida de qualquer conforto, sem os objetos mais indispensáveis à gente civilizada, faltam os aconchegos da vida da família regularmente organizada. No seu acanhado âmbito vivem, numa mistura repugnante, homens e mulheres, moços e velhos, filhos e paus. Se chega um forasteiro e lhes pede agasalho, isto é, lugar para atar a sua rede, dão-lho ali mesmo, com uma hospitalidade fácil, sem cuidarem da mulher ou das filhas. Em uma daquelas barracas da festa do Jussarateua, de que falei atrás, vi onze redes amarradas umas quase que por cima de outras, por não caberem de melhor modo em tão pequeno espaço, nas quais dormiam, segundo informei-me, outras tantas pessoas de sexos e famílias diferentes. Falta-lhes, por assim dizer, o sentimento delicado do pudor, como o respeito mútuo, e a família não tem base. O concubinato é já uma coisa natural, fácil, consentida, de regra geral e o adultério vulgar e tolerado. Não se afrontam os pais se as filhas se não casam, com quanto preferissem que casassem. Muitas vezes a única cerimônia das uniões entre os dois sexos é, como entre alguns selvagens, o mútuo consenso das duas partes; por isso, nos lugares onde vivem em grupos mais numerosos, a prostituição disfarçada sob a forma do concubinato, é geral. As mulheres banham-se nuas em lugares públicos, nas praias das cidades do interior, como terão visto quantos hajam subido o Amazonas do Pará a Manaus, lavam roupa nas margens dos seus rios e lagos com uma saia por tanga, e prostituem-se precocemente. Inconstantes e despreocupados dos sérios cuidados da vida, preferem ao sedentário o trabalho nômade. Assim acodem contentes às imigrações periódicas que é de uso fazer todos os anos para a extração da seringa (borracha) ou do óleo da copaíba; para a colheita da salsaparrilha, da castanha, ou do cravo; para a pesca do pirarucu ou da tartaruga. Não é ambição que os leva, que não a tem. O dinheiro merece-lhes pouco. Mas a civilização, 
digo mal, a falta de educação, havendo os degradado, encontram nesses ajuntamentos periódicos, onde reina a maior licença, além da satisfação do seu herdado instinto nômade, a dos vícios a que mais dão-se: a bebedice, a dança, a devassidão, a vida fácil em suma.

Depois de uma descrição tão completa e fiel, de que dão ideia pálida as transcrições acima, mas que melhor fora apreciar, em seu conjunto, no original, era lógico e justo que o autor concluísse como concluiu: "Esta gente, disse, quer a tapuia, quer a mameluca, está profundamente degradada". E mais adiante: "As raças cruzadas do Pará estão profundamente degradadas".

Agassiz indicou a meu ver o motivo real dessa degradação atribuindo-a à mestiçagem.

O resultado de não interrompidas alianças entre sangues mistos é uma classe de homens nos quais o tipo puro desapareceu, e como ele todas as boas qualidades físicas e morais das raças primitivas, deixando era seu lugar um povo degenerado, tão repulsivo como esses cães, produto de uma cadela de caça, como um gozo, com horror dos animais da sua espécie, entre os quais é impossível descobrir um único indivíduo tendo conservado a inteligência, a nobreza, a afetividade natural que fazem do cão de tipo puro o companheiro e o favorito do homem civilizado.

No entanto para explicar esta degradação, o Sr. Veríssimo procura dar primazia sobre o cruzamento a diversas outras causas, às quais de boa mente não se pode conceder mais do que o papel de causas adjuvantes.

Apela em primeiro lugar para a qualidade e os defeitos dos colonizadores, que em geral eram gente da pior espécie, proveniente, além de tudo, de um povo atrasado e sempre arredio da civilização europeia - os portugueses. A este modo de entender as coisas conviria antes de tudo contrapor o seguinte juízo do Sr. Dr. Sylvio Romero:

Qual era a esse tempo (da colonização) o estado intelectual de Portugal? Bem lisonjeiro. Tal deve ser a resposta. Um país que tinha Gil Vicente, Camões, Christovão Falcão, João de Barros, Sá de Miranda e Ferreira, atravessava uma fase brilhante do pensamento. Os colonos portugueses para aqui transportados, vinham de posse de uma cultura adiantada. Porque motivo, pois, não dirigiram a colorização mais sabiamente, aproveitando os índios, adaptando-os a si? Duas causas fornecem a explicação do fenômeno: a índole do caboclo, refratário à cultura, e a imperícia do governo da metrópole.

Mas concedo que os colonos fossem gente da pior espécie que havia em Portugal. A experiência tem demonstrado que mesmo criminosos de hábito assim transportados para terras longínquas são susceptíveis de regenerarem-se. Transferidos para um meio fundamentalmente diferente daquele em que se exercia a sua atividade criminosa, se não são criminosos natos ou de todo incorrigíveis podem se integrar na população honesta e ativa das colônias. Afirma-se que a população laboriosa da Austrália não teve outra origem senão uma mistura de deportados com a população honesta da colônia inglesa.

Em segundo lugar invoca o Sr. Veríssimo o insucesso e os defeitos das catequeses. Mas é o primeiro a reconhecer a impossibilidade de civilizar-se o índio, e ainda, que esta circunstancia frustrou os bons desejos que nutria o jesuíta de firmar sobre os índios um poderoso domínio. Acusa a falta, ou a má educação dos mestiços, mas os reconhecem incapazes de serem educados e aproveitados.

Finalmente apela o Sr. Veríssimo para o calor excessivo do clima, para a uberdade e riqueza do solo.

Mas, ao passo que o calor tem uma ação indiscutível e que se deve levar em conta, não parece que seja tão excessiva a uberdade do solo e muito menos que ela se constitua em um embaraço à civilização. Tendo demonstrado quanto era exagerada a ideia da uberdade do nosso solo, o Sr. Sylvio Romero pude dizer com razão:

Eu não contesto a fertilidade do solo brasileiro, fora um paradoxo. Contesto, porém, que a fertilidade seja um predicado do Brasil como alguns querem, ou seja, maior aqui do que por todo alhures.

Com Buckle, com Spencer, a fertilidade deve mesmo ser considerada uma das condições principais das civilizações primitivas e para o Brasil o ponto está exatamente em saber como a sua tão decantada fertilidade pode ficar de harmonia com a ausência de civilização dos aborígenes.

Parece mais feliz, e eu não teria dúvida em subscrevê-la, a doutrina do Dr. Sylvio Romero para explicar como o nosso atraso, a psicologia do brasileiro. 
Os fatores a meu ver, diz ele, são primários ou naturais, secundários ou étnicos e terciárias ou tnoraes. Os principais daqueles vem a ser o calor excessivo, ajudado pelas secas na maior parte do país; as chuvas torrenciais no vale do Amazonas alem do intensíssimo calor; a falta de grandes vias fluviais nas províncias entre o São Francisco e o Paraíba; as febres de mau caráter, reinantes na costa. O mais natural dos secundários é - a incapacidade relativa das três raças que constituíram a população do país. Os últimos, os fatores históricos chamados política, legislação, usos, costumes, que são efeitos que depois atuam também como causas.

III. Feita assim a parte de todos os fatores, discutamos como a incapacidade das raças inferiores influiu no caráter da população mestiça, transformando ou combinando em sínteses variáveis os predicados transmitidos pela herança. A escala vai aqui do produto inteiramente inaproveitável e degenerado ao produto válido e capaz de superior manifestação da atividade mental. A mesma escala deverá percorrer a responsabilidade moral e penal, desde a sua negação em um extremo, até a afirmação plena no extremo oposto.

São acordes os melhores escritores, pelo menos os que julgam a matéria pelo lado científico, em tomar como características do brasileiro, a falta de energia física e moral, a apatia, a imprevidência. "Como tipo sociológico, o povo brasileiro é apático, sem iniciativa, desanimado", diz o Dr. Sylvio Romero. A indolência da população mestiça é talvez um dos fatos sobre o qual menos se discutirá no Brasil, e não é menor o acordo unânime em atribuí-la à riqueza nativa do solo, que dispensa qualquer trabalho.

O último código penal, feliz por ter com o consenso geral, encontrado na indolência dos mestiços, uma manifestação da livre vontade de não querer trabalhar, correu pressuroso, com o art. 399, em auxílio desse prejuízo.

E para corrigir o vicio não descobriu de melhor senão alguns dias de prisão celular e uma teoria de trabalho obrigatório, destituída de toda e qualquer virtude pratica e educativa.

A indolência dos nossos mestiços é um legado dos seus maiores, que mais deve merecer da arte de educar do que das repressões penais.
A bem conhecida incapacidade de um trabalho físico continuado e regular nos selvagens tem a sua explicação natural na fisiologia comparada das raças humanas.

Ainda há poucos anos, o Sr. Dr. Baptista de Lacerda, com uma admiração um tanto ingênua, supôs ter descoberto que, ao contrário do que afirmam os viajantes e escritores, o índio brasileiro não é dotado de grande força muscular. Dos seus estudos dinamométricos, tirava a justa ilação, que o índio não poderia substituir o negro como instrumento de trabalho; a sua produção seria descontínua, necessitando intervalos maiores de repouso. Deixarei em paz as conjecturas hipotéticas do Dr. Lacerda a respeito deste ponto.

Ensina Spencer que já Perron havia demonstrado, com o dinamômetro em punho, que os Tasmânios, apesar de uma aparência de grande vigor, tinham muito pouca força muscular, e como eles os Papous, os Damaras, etc., que Burton estudando precisamente raças americanas, havia chegado a esta conclusão geral - que é muito fraca a força muscular dos selvagens.

Este fato reconhece duas causas principais: a insuficiência da nutrição devido a uma alimentação de má natureza e sempre incerta na vida selvagem, e principalmente uma insuficiência relativa da inervação.

Spencer demonstra que é o sistema nervoso e não o muscular, em que o Dr. Lacerda procurava a explicação do fenômeno, que dá a medida do desenvolvimento da força miótica; e ainda, que esta guarda uma relação direta de dependência com o estado e o desenvolvimento das funções psíquicas, de sorte que o menor desenvolvimento do cérebro do selvagem explica suficientemente a sua fraqueza física. Se agora refletirmos que, transmitida esta celebração insuficiente aos seus descendentes mestiços, estes, por exigência da luta pela existência toda intelectual das civilizações superiores, tiveram necessidade de aproveitá-la principalmente no sentido da inteligência, havemos de compreender por que os mestiços dos selvagens são capazes de inteligência desenvolvida, mas são fracos, indolentes, imprevidentes.

De produtos tão abastardados, tão despidos de sentimentos e de qualidades Moraes superiores, como são os que ele nos ensina a conhecer, diz o Sr. Veríssimo:

Pelo lado puramente intelectual não há dúvida que ganharam. O fato já hoje incontestável da superioridade intelectual no Brasil, dos mestiços, encontra na Amazônia mais uma prova. Não seria difícil 
mostrar que são mamelucos ou curibocas os seus representantes intelectuais, se a isso se não opusesse a ridícula vaidade dos mesmos. Voltando, porém, à gente que mais diretamente nos interessa, repetirei que nela o desenvolvimento intelectual é sem dúvida muito superior ao do índio puro.

A estas observações acrescentarei uma reflexão, escreve por sua vez o Dr. Ladislau Netto (Revista da Exposição Anthropologica Brasileira,

Rio de Janeiro, 1882 e é que em relação aos mestiços oriundos da raça branca com a preta, mostram-se eles ordinariamente mais inteligentes que os mestiços resultantes da junção do sangue branco ao sangue americano, ainda que menos refletidos, menos metódicos, no que produzem, e se me é permitido dizê-lo, menos equânimes.

Pode ser, porém, mais completa a interpretação da imprevidência que revela a nossa população mestiça em rude contraste com o extremo oposto dos brancos, silicet dos portugueses, que, mesmo chegados pobres, paupérrimos ao nosso país, no fim de pouco tempo são os seus grandes capitalistas.

Como demonstra Spencer, a imprevidência, tão conhecida, dos selvagens, tem a sua origem no estado emocional deles. A imprevidência é uma consequência da impetuosidade relativa dos selvagens, estado que muito se aproxima da ação reflexa de que proveio; é uma consequência da carência no fenômeno psíquico da determinação voluntária, de emoções superiores que refreiem e dominem as emoções simples.

Um dos traços especiais do caráter primitivo, diz Spencer (Príncipes de Sociologie, Paris, 1886), descrevendo o homem primitivo emocional, o qual em parte depende da impulsividade, é a imprevidência. $\mathrm{O}$ desejo imediato que tende a obter para o agente a satisfação de seus apetites ou aplausos em troca de um ato de generosidade de sua parte, exclui o temor dos males futuros, não fazendo grande impressão na consciência, o homem não tem realmente motivo algum que o aguilhoe e o impila ao esforço, a não ser a paixão estouvada e descuidosa que o absorve em favor do presente.

Algumas páginas e acrescenta:

O caráter cardeal da impulsividade supõe a passagem súbita, quase reflexa, de uma paixão única à conduta que ela produz: implica, pela ausência de sentimentos oposto que a consciência se compõe de representações menos numerosas e mais simples; importa que o ajustamento das ações internas às ações externas, não leva em consideração consequência longínquas; que esse ajustamento não se estende tão longe no tempo e no espaço. O mesmo se dá com a imprevidência que é o resultado dessa impulsividade: o desejo se dirige de um só golpe ao objeto que deve satisfazê-lo; a imaginação representa fracamente os resultados secundários da satisfação dos desejos; nenhuma necessidade longínqua vem apresentar objeções.

Esta análise psicológica dá sem dúvida a explicação inteira do caráter indolente e imprevidente do mestiço brasileiro, capaz de atingir, como aconteceu na Amazônia, onde tão ao vivo nele pinta o Sr. José Veríssimo, às raias de uma verdadeira degradação moral.

Do ponto de vista da psicologia criminal, este exame, a que procurei dar o desenvolvimento que ele requeria, tem valor e aplicações inestimáveis.

Ele nos mostra que no selvagem, de um lado, é rudimentar ainda, esboçado apenas o sentimento do direito de propriedade, e de outro lado, que a impulsividade, quase automatismo reflexo, domina as suas ações. Nos demonstrou ainda esse exame que este estado psíquico pode ser transmitido por herança, quase em pureza e vigor nativos, aos seus descendentes mestiços.

Ora, como estes estados psíquicos dominam os crimes contra pessoas, tanto quanto os crimes contra propriedade, é intuitivo que por defeito de organização, por insuficiência e desarmonia do desenvolvimento fisiopsicológico, não só o índio e o negro, mas ainda os seus mestiços devem ser menos responsáveis do que os brancos civilizados.

Falta-lhes a consciência plena do direito de propriedade. E a consciência do direito é momento capital, elemento constitutivo da qualificação de criminalidade (Berner, Tobias Barreto).

Domina-os a impulsividade. E a impulsividade - seja patológica por destruição mórbida do freio superior dos motivos psíquicos de ordem mais elevada, das emoções nobres, seja congênita e constitucional por falta ou por insuficiência do desenvolvimento desse freio -, é sempre a mesma e tem o mesmo alcance. Em ambos os casos ela mantém dominada a livre determinação voluntaria e destrói pela base toda e qualquer responsabilidade que se funde na uberdade do querer.

IV. As objeções que se possam levantar contra este modo de julgar carecem examinadas desde já. Com aparências de fundamento, se poderia por exemplo objetar à explicação da imprevidência dos mestiços por uma 
herança da impulsividade selvagem, a apatia tantas vezes observadas, e tão salientada no caráter do mestiço pelo Sr. Veríssimo.

No entanto, a explicação natural do fenômeno destrói esta contradição aparente, pois a apatia constitui manifestação de um vicio orgânico, constitucional, que, como a impulsividade, poderia ser transmitido por herança. A apatia já tinha sido observada nos próprios índios americanos e dela pode dizer Spencer:

Pode bem ser que se as raças americanas não se mostram prontas a agir ao primeiro impulso, provenha esse defeito de uma inércia constitucional há entre nós pessoas cuja igualdade habitual de humor provém de uma falta de vitalidade; são pessoas semiacurvadas e as emoções que as irritações produzem nelas tem menos intensidade do que nos outros.

Assim, a apatia dos mamelucos, que bem pode ser o fruto da constituição orgânica do mestiço, traindo o vicio degenerativo do cruzamento, também podia ser perfeitamente um legado hereditário.

No entanto, Spencer salienta bem que essas raças, ordinariamente impassíveis, podem entrar em um furor exagerado por motivos insignificantes ou fúteis.

O Sr. Veríssimo consigna a respeito dos mestiços uma observação idêntica, que tenho muito a peito salientar aqui, porque ela atesta em favor da procedência hereditária e constitucional que atribuo à degeneração dos mestiços contra as explicações que do fato procura dar este autor.

O seu caráter (do mameluco), diz ele, carece absolutamente de vigor, e como o caráter não é talvez senão o conjunto das forças morais do indivíduo, aplicadas ao bem ou ao mal, pudesse dizer, sem arriscar um elogio, que é possível não mereçam, que são de boa índole, e de instintos pacíficos. Ou seja, verdadeira a nossa teoria - e então seriam negativas aquelas virtudes -, ou tenham eles, com efeito, o que não creio, natural e fundada aversão aos atos criminosos, o que é certo é que tais atos não são por ventura tão frequentes nesta região inteiramente dominada por eles, como em outras do império. Nota-se, porém, que os poucos numerosos crimes por eles cometidos - refirome a crimes contra pessoas - são geralmente revestidos de circunstâncias cruéis em que sente se a influência atávica do selvagem.
V. Se me pode objetar ainda que este estado de degradação dos mestiços, quando fosse verdadeiro da Amazônia, constituiria em todo caso uma exceção no país. E isto em primeiro lugar tenderia a provar que causas outras fora do mestiçamento influíram nesse processo de degeneração, e em segundo, que esta exceção toda local em rigor não deveria influir para se abrir no código uma atenuante geral ao princípio da responsabilidade penal.

Sou o primeiro a convir em que realmente a população mestiça da Amazônia deve constituir uma exceção no país, pois não sei se de outra se poderia avançar o severo juízo que a seu respeito emitiu um escritor do merecimento do Sr. Veríssimo.

É o que há a fazer para arrancar as raças cruzadas do Pará ao abatimento em que jazem? Inquiria o autor referido. Pensamos que nada. Esmagá-las sobre a pressão enorme de uma grande imigração, de uma raça vigorosa que nessa luta pela existência de que falia Darwin as aniquile assimilando-as parece-nos a única coisa capaz de ser útil a esta província. E ai dela se assim não for!

Posteriormente ele modificou sua opinião sobre o aproveitamento possível das raças cruzadas, mas isso sem prejuízo da sua opinião sobre o estado de degradação delas...

No entanto, é precisamente este caráter de exceção que mais confirma a meu ver a procedência hereditária, a influência do mestiçamento nessa degeneração.

Causas múltiplas, bem o creio, colaboram nessa obra: o alcoolismo, a licença, as emanações miasmáticas, a inadaptação do elemento branco aos climas tórridos, como o provou com eloquência o miserável estado de degeneração dos portugueses na Malásia.

Mas esses fatores atuaram e atuam, uns em toda a extensão do país e outros em quase toda, e só ali no Pará e Amazonas a degradação do mestiço atingiu o grau descrito pelo Sr. Veríssimo. Porque, senão porque atualmente predomina ali no mestiçamento o menos aproveitável dos nossos elementos étnicos, o índio?

VI. Afastada a parte da objeção que se refere à intervenção do código e que será tomada em consideração na próxima conferência, o seu exame nos leva ao do mestiçamento no resto do país e sob as suas outras formas. 
A exceção da população mestiça da Amazônia consiste menos em uma diferença substancial, do que em diferença de intensidade ou de grau.

A indolência, a apatia, a imprevidência, todos os maus predicados que o Sr. Veríssimo descobre e aponta nos mameluco paraense, facilmente podem ser descobertos nos mestiços de todo o país.

A diferença em favor dos outros mestiços brasileiros está na maior capacidade deles para a civilização, na educabilidade maior de que dão provas, e que muito atenua as suas más qualidades.

Os mestiços do negro, as diversas espécies de mulatos, são incontestavelmente muito superiores pela inteligência aos outros mestiços do país. Temos tido homens de grande talento, de merecimento incontestável não só quase brancos, mas ainda mestiços quase negros. Neste particular, me parece razoável considerar os mestiços que tendem a voltar a qualquer das raças puras, quer a branca principalmente, quer mesmo a negra, como muito superiores aos verdadeiros mulatos, de primeiro ou segundo sangue.

Parece que é nestes últimos precisamente que mais sensível se torna o desequilíbrio do mestiço e que o que eles ganham em inteligência perdem em energia e mesmo em moralidade. O desequilíbrio entre as faculdades intelectuais e as afetivas dos degenerados, o desenvolvimento exagerado de umas em detrimento das outras tem perfeito símile nesta melhoria da inteligência dos mestiços com uma imperfeição tão sensível das qualidades morais, afetivas, que deles exigia a civilização que lhes foi imposta. E esta observação estreita ainda mais as analogias que descubro entre o estado mental dos degenerados superiores e certas manifestações espirituais dos mestiços. Nestes casos como que se revela em toda a sua plenitude, em toda a sua brutalidade, o conflito que se trava entre qualidades psíquicas, entre condições físicas e fisiológicas muito desiguais de duas raças tão dessemelhantes, e que a transmissão hereditária fundiu em produto mestiço resultante da união ou cruzamento delas.

A sensualidade do negro pode atingir então às raias quase das perversões sexuais mórbidas. A excitação genésica da clássica mulata Brasileira não pode deixar de ser considerada um tipo anormal.

"Nunca se frisou bastante, diz o Sr. José Veríssimo (A educação nacional, Pará, 1890), a depravada influência deste característico tipo brasileiro, a mulata, no amolecimento do nosso caráter". "Esse fermento do afrodisísmo patrício", como lhe chama o Sr. Sylvio Romero, foi um dissolvente da nossa virilidade física e moral. A poesia popular brasileira nela mostra, com insistente preocupação apaixonada, em toda a força dos seus atrativos e da sua influência. O povo amoroso se não fatiga em celebrar-lhe, numa nota lúbrica, os encantos, que ele esmiúça, numa sofreguidão de desejos ardentes. Canta-lhe a volúpia, a magia, a luxuria, os feitiços, o faceirice, os dengues, os quindins, como ele diz na sua linguagem piegas, desejosa, sensual.

Quando, porém, o produto mestiço tende a voltar a uma das raças puras, esse equilíbrio instável tende por sua vez a melhorar e como que as boas qualidades encontram uma base mais solida para as suas manifestações.

Em apoio desta minha opinião encontro nos autores observações diversas.

Notei até por vezes, diz o Dr. Ladisláo Netto, que nas famílias mestiças da primeira categoria (branco e negro), em que os caracteres africanos denunciam-se em manifestação atávica, num certo indivíduo, mais do que em seus irmãos ou primos, dá-se o interessante fenômeno de ser aquele indivíduo o mais inteligente representante da família, ou de se encontrar na sua individualidade qualquer aptidão artística, imaginação mais ardente, uma, sequer, mas viva e mais pronta percepção. Feliz e providencial compensação para a vítima do atavismo, que mais o é dos despeitos de seus próprios pais e irmãos, cujas pretensões mais ou menos infundadas a uma brancura, às vezes duvidosa, foram por aquele natural fenômeno inteiramente burladas.

O Dr. Couto de Magalhães, por seu turno, diz dos mamelucos: "Sabese hoje que o melhor mestiço é aquele que resultar do tronco branco, no qual se haja infiltrado um quinto de sangue indígena".

VII. Destes dois princípios fundamentais - a herança pela larga transmissão dos caracteres das raças inferiores a que dá lugar, e o mestiçamento, pelo desequilíbrio ou antes pelo equilíbrio mental instável que acarreta -, decorre, me parece, a explicação fácil e natural da nossa psicologia de povo mestiço. Por sua vez, dão eles também a explicação mais razoável de certas formas da criminalidade crioula.

Estão neste caso os chamados atentados de raça, em que exercem poderosa influência o despeito, a animadversão, o ódio contra as raças 
superiores ou dominadoras por causa do desprezo de que são ou se supõem objeto as raças inferiores ou dominadas.

Os prejuízos de raça, de casta, de cor, etc., influem por dois modos distintos: ou alimentando o ódio das raças oprimidas contra as dominadoras; ou criando no seio mesmo das raças dominadas castas rivais e rancorosas, em que cada qual mais se esforça por imitar ou parecer pertencer à raça dominante.

Orgeas vê no prejuízo de cor, de casta, etc., um fenômeno natural, uma afinidade étnica, destinada a velar pela pureza das raças.

Mas esta opinião, sobre não se conciliar com os largos mestiçamentos históricos de que ele mesmo cita exemplos, deixa sem explicação a preferência, ou tendência a cruzar com as raças superiores, que tanto preocupa as castas, as raças inferiores.

Esta animosidade relativamente mais se faz sentir e se torna notada e saliente no nosso país entre os mestiços e as raças inferiores, e nos mestiços entre si.

O Dr. Anselmo da Fonseca dá conta do fato nos seguintes termos:

É de observação que no Brasil, como em todos os países onde existiu a escravidão africana, os homens livres, pretos ou de cor, são geralmente os principais adversários dos escravos, os que mais advogam os interesses da escravidão contra a liberdade, os últimos com cuja simpatia podem contar os míseros que hoje são cativos.

De um mestiço, dos mais distintos professores desta faculdade, conta-se que costumava justificar a sua franca hostilidade aos negros e mestiços candidatos ao diploma de médico ou a alguma das cadeiras do professorado, declarando que - de negros na escola bastava ele. Seja influência da nossa origem portuguesa, por força da tendência dos iberos a cruzar com as raças inferiores; seja virtude especial da nossa população branca, no que não creio; ou seja, finalmente mais uma influência do caráter do povo brasileiro, indolente, apático, incapaz de paixões fortes, o certo é que os prejuízos de cor, que certamente existem entre nós, são pouco apurados e intolerantes da parte da raça branca. Em todo o caso, muito menos do que dizem ser na América do Norte.
Como espécimes da influência deste prejuízo na criminalidade do país, os anais da escravidão registram numerosos exemplos.

Enumera o, Dr. Fonseca, na sua obra, uma série de crimes revoltantes contra os escravos, cometidos por negros, ou mulatos, e afirma que dos indivíduos que no país serviam de algozes aos escravos - feitores, capitães de mato, corretores de escravos - dois terços pelo menos eram negros ou mestiços.

Como Ruy Barbosa, o Dr. Fonseca adota a explicação de Victor Hugo, para quem era esse procedimento devido a que "tais indivíduos acreditam que, odiando a raça africana, ajudando a persegui-la, parecerá a todos que eles não têm o sangue dela, nem lhe são ligados por laço algum".

Qualquer que tivesse sido, a seu tempo, o valor educativo e moralizador desta explicação, não acredito que ela possa pretender as honras de uma interpretação completa e rigorosamente científica. Compreende-se mal que a insânia da vaidade, de uma simples vaidade banal e governável, pudesse atingir, assim em massa, a uma raça inteira, e ao mesmo tempo revelar-se tão intensa e firme a ponto de não recuar diante de crimes verdadeiramente atrozes. Sente-se que esse proceder deve ter raízes mais profundas e naturais, que o justifiquem, que o tornem menos repugnante e que o representem como sendo o fruto de uma tendência psíquica menos modificável e voluntaria, isto é, livre, do que se parece querer admitir naquela explicação.

A fase do desenvolvimento sociológico em que se acham as raças negras dá explicação suficiente da tolerância, da falta de repugnância dos negros, pela escravidão dos seus irmãos.

É hoje ponto inconteste que, na vida dos povos, a instituição da escravidão é um fenômeno natural, que marca certo período ou fase da sua evolução social.

Em quase toda a parte da África que nos ocupa, diz Abel Havelacque, a escravidão é uma instituição social, não somente aceita, mas ainda considerada perfeitamente natural e indispensável... Eu conheci em Ruffisca, diz Sanderval, o velho rei Sangouné Quando eu o vi, o monarca decaído estava acompanhado de três senhores da sua ex corte. Sangouné já não tem ilusões; ele está convencido, e o diz da melhor vontade, que a supressão da escravidão arruinou para sempre a ordem social. E, notemo-lo, a opinião do velho rei não é somente a convicção das classes 
dirigentes, é igualmente a do rebanho servil e dos infelizes que são vítimas da civilização do seu país. É assim que, como vimos acima, as próprias mulheres, espécie de semiescravas, acham legítima e justa a sua sorte. O escravo, que se liberta, se possui algum pecúlio, tem como primeiro cuidado comprar escravos por sua vez.

Para o negro, como para seus mestiços que deles receberam, ou herdaram um sentimento idêntico, nada, portanto, mais natural do que a legitimidade da escravidão.

Onde a intervenção da vaidade se torna aceitável, é na explicação dos maus tratamentos, dos crimes cometidos por eles contra os escravizados. Mas esta vaidade é ainda um fenômeno natural, inerente mesmo à organização infantil desses indivíduos. É ela ainda um estádio do desenvolvimento emocional dos povos e marca a transição dos sentimentos egoísticos para os sentimentos altruísticos.

Antes que os sentimentos que procuram a sua satisfação na felicidade de outrem existam em graus variáveis, diz Spencer, outros sentimentos que encontram a sua satisfação na admiração que se inspira ao próximo existem em graus consideráveis. Os próprios animais mostram prazer em se ver aplaudidos, é no homem a vida social abre desde muito cedo e amplia esta fonte de prazer. Por maior que seja a vaidade do homem civilizado, a do homem não civilizado a excede muito.

E Spencer mostra que esta vaidade não se limita aos enfeites e ostentações da moda, mas tem ainda poderosa influência na conduta dos povos selvagens e bárbaros. Crimes mesmo têm a sua origem nas exigências de uma vaidade, que chega a ponto de abafar a voz do sangue, dando lugar a infanticídios de meninas, nos povos em que o amor da ostentação torna exorbitantes as despesas do casamento.

A objeção mais séria que se poderia levantar contra a legitimidade desta interpretação é a da existência de mestiços abolicionistas e de negros e mestiços dotados dos mais nobres sentimentos altruístas. Esta circunstância, porém, ao invés de invalidar, mais completa e verdadeira torna a regra estabelecida. Desde que os defeitos apontados são defeitos naturais, consequência do estado ou fase do desenvolvimento de uma raça, seria absurdo pretender que só nos negros e nos mestiços se não possam observar essas naturezas excepcionais e privilegiadas que conseguem preceder de muito tempo a massa da sua raça no aperfeiçoamento moral e intelectual. Em todas as raças humanas, em todos os povos o fato tem sido observado, e não serão o negro e os mestiços que hão de abrir uma exceção à regra. Isto, quando não se queira contar em favor do mestiço com a transmissão das qualidades mentais da raça superior.

VIII. No entanto, é de todo impossível precisar, estabelecer leis fatais e invariáveis à transmissão hereditária dos caracteres atávicos aos mestiços. E esta circunstância complica sobremodo a tarefa do perito nos exames médicos-psicológicos. Mesmo nos mestiços mais disfarçados, naqueles em que o predomínio dos caracteres da raça superior parece definitiva e solidamente firmado, não é impossível revelar-se de um momento para outro o fundo atávico do selvagem.

Requerem particular e séria meditação por parte do psicólogo, do médico-legista, as curiosas observações do Sr. Ladisláo Netto sobre este ponto.

É pela época da puberdade, diz ele (Do atavismo, Revista da Exposição anthropologica), que em geral mais claro se manifestam os sintomas atávicos nas pessoas mestiças, muitas vezes já de cor perfeitamente branca, e tendo o sangue africano em adiantadíssima diminuição nas veias.

Neste caso toda a constituição do indivíduo sofre notável alteração; alem da pigmentação pronunciada nas regiões a que acima me referi (cavidade bucal, mucosa da arcada alveolar, das pálpebras, dos lábios, narinas, tecido celular da base da unha) e que se estende aos mamelões e aos órgãos reprodutores de ambos os sexos, nota-se o desenvolvimento do mento, o aparecimento do cheiro acre nauseabundo da transpiração axilar, denominado catinga, o encrespamento do cabelo, o colorido mais vigoroso de toda a pele, e quase sempre uma tal ou qual diminuição do próprio ângulo facial.

A todas estas modificações acresce pronunciada indolência, apatia excessiva e profunda abstração, ou antes uma inação intelectual, que lembra muito particularmente a estúpida inaptidão do negro. A esse abatimento, entretanto, antepõe-se um quer que seja de lúbrico, e um como desabrochar pujante de bruta sensualidade, a que só podem contrapor eficiente dique os liames da mais rigorosa educação moral. Felizmente, este que eu chamarei estado mórbido tem efêmera duração: todos os fenômenos que o acompanham vão-se aos poucos 
modificando, e, ou totalmente desaparecem, ou deixam apenas vislumbre de sua passagem no organismo.

Assim é que em muitos indivíduos, que manifestaram entre os quatorze e dezesseis anos quase todos estes indícios atávicos, vemolos desaparecerem depois de vinte anos, inclusive o próprio encrespamento e aspereza do cabelo, na maior parte dos casos tenaz e tão rebelde característico da origem africana.

Aproximando destas as considerações do insigne psiquiatra alemão, Krafftebing, sobre o valor legal da puberdade, mais de jeito vos habilitarei a julgar da sua importância e porquanto complicam-se elas pela adjunção do momento de raça.

O código (alemão) inspirou-se com felicidade, diz ele ( $\mathrm{La}$ responsabilitá criminale, etc.), quando fixou o princípio da responsabilidade absoluta aos 18 anos, porque só nesta idade a maturidade sexual é completa, e se sabe bem como o período de desenvolvimento se acompanha de alterações do caráter e de perturbações intelectuais que facilmente passam despercebidas. De fato, as funções do sistema nervoso em geral e as do cérebro em particular são necessariamente influenciadas pelo aparecimento de novas funções em órgãos que até então se achavam em repouso. Mesmo no estado normal, o desenvolvimento da puberdade se acompanha de transformações de sentimento e de uma metamorfose completa do indivíduo com tendência ao romântico divagar da imaginação, a aspirações sentimentais ou ações melancólicas e hipocondríacas. Se a estes fenômenos fisiológicos do desenvolvimento normal se adicionam, ou uma predisposição hereditária a perturbações psíquicas, ou excessos sexuais como o onanismo, ou histeria, a clorose, a anemia, ou enfim perturbação da menstruação, a modificação do caráter pode adquirir uma intensidade mórbida e associar-se a alucinações, ânsia precordial ou nostalgia, impelir a atos culposos e até a crimes. $\mathrm{O}$ crime de incêndio é especialmente frequentíssimo nestas condições, porque fácil torna-se à criança cometê-lo.

Mas é impossível desconhecer, mesmo com limitada prática de exames médicos-psicológicos, a importância extraordinária desta observação.

O verniz de civilização, já de si tão frágil, que nas raças superiores cobre e domina a organização automática e instintiva, fica reduzido a nada nos mestiços, se alem do seu desequilíbrio de organização sempre possível, deve o médico atender à possibilidade destas transmissões atávicas transitórias. E como desprezá-las? Se no exame psicológico de um alienado é de regra submeter a rigoroso inventário as qualidades e taras dos seus maiores, no intuito de descobrir em longínquos antepassados o veio da deterioração mental, porque havemos de desconhecer e desprezar as leis da hereditariedade, quando temos à mão na psicologia dos ascendentes a explicação normal do estado mental dos mestiços?

IX. Chegando ao termo desta análise, vedes bem, senhores, que de duas ordens distintas são os direitos a uma responsabilidade atenuada que a maioria da população brasileira pode disputar à repressão penal. Uma de natureza mórbida, ou anormal, conexa com a influência degenerativa que sobre frações dela puderam exercer causas múltiplas, à frente das quais coloquei o cruzamento entre raças muito dessemelhantes. Os mestiços da Amazônia são o seu tipo. Outra de ordem natural, dependente da desigualdade biossociológica das raças que a compõem. Aqui melhor fora dizer-me antes existe uma responsabilidade moral diversa daquela que se exige dessas raças, do que, que existam em rigor causas de verdadeira irresponsabilidade penal. Os índios e os negros são os representantes desta categoria.

Dos mestiços, eu não pretendo certamente que sejam todos irresponsáveis. Tanto importaria afirmar que são todos degenerados.

Mas acredito e afirmo que a criminalidade no mestiço brasileiro é, como todas as outras manifestações congêneres, sejam biológicas ou sociológicas, de fundo degenerativo e ligada às más condições antropológicas do mestiçamento no Brasil.

Entendo que se podem distribuir os mestiços por três grupos distintos.

Primeiro, o dos mestiços superiores, que ou pela predominância da raça civilizada na sua organização hereditária, ou por uma combinação mental feliz, de acordo com a escola clássica, devem ser julgados perfeitamente equilibrados e plenamente responsáveis.

Segundo, o dos mestiços evidentemente degenerados, que, em virtude de "anomalias de sua organização física, bem como de suas faculdades intelectuais e morais", devem ser considerados, na frase de Morei, "tristes representantes de variedades doentias da espécie". Estes, como já afirmava o eminente psiquiatra, "não podem ser considerados como casos dessas moléstias ordinárias que tem a sua panaceia nas oficinas farmacêuticas, nem 
como a expressão de uma dessas tendências perversas cujo castigo se acha fixado nas disposições penais de nossos 'códigos judiciários'. Dentre eles, uns devem ser total, outros parcialmente irresponsáveis".

Terceiro, finalmente a dos mestiços comuns, produtos socialmente aproveitáveis, superiores às raças selvagens de que provieram, mas que, já pelas qualidades herdadas dessas raças, já pelo desequilíbrio mental que neles operou o cruzamento, não são equiparáveis às raças superiores e acham-se em iminência constante de cometer ações antissociais de que não podem ser plenamente responsáveis. São casos todos de responsabilidade atenuada.

\section{CAPÍTULO VII}

\section{A DEFESA SOCIAL NO BRASIL}

Sumário - Causas de irresponsabilidade no Brasil; sua influência na extrema generalização possível da impunidade. Inconvenientes de uma modificação parcial do código para corrigi-lo; necessidade de uma reforma radical. Defeitos fundamentais da nossa legislação penal: a unidade do código. Menoridade. Dualidade da magistratura seus inconvenientes. O júri na organização judiciária do estado da Bahia. Efeitos desastrosos da reclusão dos menores na penitenciária deste Estado. A pluralidade da legislação penal no Brasil; oportunidade das reformas da escola criminalista positiva.

I. A conclusão paradoxal a que cheguei na última conferência é de um rigor lógico indiscutível.

Ela se compreende. A civilização ariana está representada no Brasil por uma fraca minoria da raça branca a quem ficou o encargo de defendê-la, não só contra os atos antissociais - os crimes - dos seus próprios representantes, como ainda contra os atos antissociais das raças inferiores, sejam estes verdadeiros crimes no conceito dessas raças, sejam ao contrário manifestações do conflito, da luta pela existência entre a civilização superior da raça branca e os esboços de civilização das raças conquistadas, ou submetidas.

Era, portanto, natural que o legislador brasileiro confundisse todos esses atos sob a rubrica geral de crimes, e os submetesse aos meios de repressão, que, a seu juízo, deviam garantir a ordem social sobre que repousava a civilização que ele tinha em vista defender.

Para abranger, porém, em uma formula única atos antissociais tão diferentes, fazia-se mister que o conceito fundamental da repressão fosse sobretudo bastante compreensivo e generalizado. Deste jeito, se algum dia se viesse a demonstrar que o critério escolhido tinha sido falso, ou mesmo apenas insuficiente, os ataques dirigidos contra a sua legitimidade deveriam 
parecer trazer como consequência inevitável o compromisso, ou o aniquilamento de toda a ordem social a que ele servia de garante.

Foi o que sucedeu com o livre arbítrio. Se até hoje a sua eficácia pode parecer suficiente, é que os nossos códigos, impondo às raças inferiores o estalão por que aferem a criminalidade da raça branca, de fato, substituíram inconscientemente na aplicação pratica da repressão criminal o livre arbítrio pela defesa social, punindo, com manifesta contradição, em nome da liberdade de querer, a indivíduos certamente perigosos, mas completamente inimputáveis.

Podeis agora compreender em que sentido exato considero os crimes das raças inferiores, do número dos crimes culposos ou involuntários. Menos por certo porque neles deixasse de ter havido uma intervenção da vontade, do que pelo fato de não implicarem sempre manifesta intenção criminosa, e ainda por importar a sua punição na escola clássica, do mesmo modo que nos outros crimes involuntários, palpável derrogação inconsciente ao princípio do livre arbítrio.

II. Todavia esta demonstração da incoerência e insuficiência da escola clássica, pelo absurdo das conclusões lógicas de seus princípios, aplicados à repressão dos crimes no nosso país, não nos deve levar a advogar ou pedir que o legislador brasileiro procure preencher a lacuna que, do ponto de vista do livre arbítrio, demonstrei existir na legislação penal pátria, e insira nos códigos uma escusa de qualquer espécie para os crimes cometidos pelas raças inferiores.

Por mais dura e iníqua que para os nossos hábitos mentais de hoje possa parecer esta defesa social pela aplicação absoluta dos princípios da escola clássica, sem a menor atenção aos modificadores da imputabilidade, em todo caso repousa por enquanto sobre essa aplicação a garantia da ordem social no país.

Mas nem tem isso sequer às honras de uma inovação. Em todos os tempos, à sombra, sob a tolerância e em nome do suposto livre arbítrio, se puseram em ação medidas repressivas, mesmo de extremo rigor que, de fato, nenhuma relação guardavam com a responsabilidade dos punidos.

Não nos ensina a história, escreve Coutagne, que em todas as épocas a administração do castigo tem variado, não de acordo com a noção abstrata da intenção criminosa, mas segundo os perigos que corre a civilização, ameaçada de momento em tal ou tal das suas bases? Os suplícios dos heréticos na sociedade religiosa da Idade Média e as execuções dos suspeitos durante a Revolução Francesa eram inspirados por vistas opostas, mas igualmente lógicas e tendiam a corresponder às necessidades do momento.

A agravação particular que a nossa antiga legislação penal descobria na circunstância de ser o crime cometido pelo escravo contra o seu senhor, não se justificaria, por certo, pela admissão no criminoso de uma dose maior de livre arbítrio; mas tão somente pela intenção manifesta de prestar o legislador mais uma sanção e garantia à instituição servil, hoje condenada.

Enquanto aguardamos, pois, que o lento preparo, a evolução natural dos espíritos tornem possível uma execução completa e harmônica das ideias e princípios da escola criminalista positiva, maior perigo existe, como justamente ensinam Ferri, Puglia e outros, em entibiar ainda mais a repressão dos crimes, enxertando as ideias novas no velho edifício da teoria clássica, do que em deixar sem correção parcial defeitos de um sistema de repressão que reclama substituição completa.

Não importa isto reconhecer eu conceder que, mesmo com todos os seus erros e contradições, a escola clássica está habilitada a dispensar indefinidamente a adoção e execução das novas ideias.

De fato, entre nós principalmente o seu sistema de repressão não é só irracional e insustentável por se firmar em uma contradição manifesta que não poderá subsistir por muito tempo, ele é ainda de todo insuficiente.

Infelizmente o Brasil é país em que a constituição republicana cometeu o grande e duplo erro de adotar, com a unidade do código penal, a dualidade da magistratura; em que a velha codificação processual, toda remendada, prima atualmente pela desarmonia em que vive de um lado com o código penal da União, de outro lado com as organizações judiciárias dos estados; em que a execução das penas, os meios penais, nunca obedecem ainda hoje, a um sistema racional qualquer; em que o júri, com todos os defeitos que lhe são inerentes, achou meios, na indiferença e incapacidade da massa da população, de se tornar mais perigoso do que em toda a parte; em que os alienados, a não ser no Rio de Janeiro, estão em condições mais precárias do que os da França antes de Pinel; em que, além da ausência completa de meios educativos de eficácia real, a infância se acha de todo sem proteção contra a aprendizagem e a educação do crime. 
Em tal país, o gérmen da criminalidade - fecundado pela tendência degenerativa do mestiçamento, pela impulsividade dominante das raças inferiores, ainda marcadas do estigma infamante da escravidão recentemente extinta, pela consciência geral, prestes a formar-se, da inconsistência das doutrinas penes fundadas no livre arbítrio -, semeado em solo tão fértil e cuidadosamente amanhado, há de por força vir a produzir o crime em vegetação luxuriante, tropical verdadeiramente.

III. Posso iludir-me, mas estou profundamente convencido de que a adoção de um código único para toda a república foi um erro grave que atentou grandemente contra os princípios mais elementares da fisiologia humana.

Pela acentuada diferença da sua climatologia, pela conformação e aspecto físico do país, pela diversidade étnica da sua população, já tão pronunciada e que ameaça mais acentuar-se ainda, o Brasil deve ser dividido, para os efeitos da legislação penal, pelo menos nas suas quatro grandes divisões regionais, que, como demonstrei no capítulo quarto, são tão natural e profundamente distintas.

Estamos habituados, diz Orgeas, a generalizar todos os fenômenos que observamos em torno de nós, e é da mania da generalização que provém todas as ideias falsas que tem curso através do mundo. O que é verdadeiro nos climas temperados é falso nos climas tórridos. Tudo o que se refere ao homem, na ordem física como na ordem moral, varia com a latitude, e não é preciso grande espírito de observação para perceber que os princípios, absolutos, gerais, abstratos, são falsos e conduzem a resultados absurdos.

Foi ao vezo de generalizar em tudo que obedeceram os portugueses e seus descendentes com a ideia de um código penal único para o Brasil.

Também não é difícil salientar os numerosos absurdos a que essa ideia nos tem conduzido.

IV. Nenhum exemplo será ilustrativo do que o da menoridade no Brasil.

O código do império havia limitado aos quatorze anos as regalias da menoridade (art. 10, § 2); salvando a hipótese de se provar que o menor de quatorze anos, havia obrado com discernimento (art. 13).
Reconhecendo embora que o desenvolvimento psíquico varia consideravelmente de indivíduo a indivíduo, Tobias Barreto aplaude, como muitos outros autores, a praxe de se fixar um termo invariável à menoridade.

Pronunciou-se, por isso, fortemente contra a doutrina do art. 13 do código antigo, fazendo consistir toda a sua argumentação na dificuldade prática de se determinar se a criança obrou ou não com discernimento, como se; por acaso, fosse este problema de freniatria médico-legal mais difícil e insolúvel do que tantos outros em que, em nome do livre arbítrio, se questionava a integridade mental do criminoso adulto.

Ainda neste particular, Tobias Barreto, o iniciador no Brasil do estudo positivo do direito, não teve a intuição exata da lei histórica a que está obedecendo o desenvolvimento da prova em matéria processual. Escapou-lhe essa sucessão, tão bem estabelecida por Tarde e aceita pelos criminalistas italianos, por que tem passado à prova, desde os ordálios e os duelos judiciários, na fase teológica, da tortura na fase legal, e do júri na fase política, até o seu sucessor lógico e natural - a perícia científica na fase; positiva.

E então, se o preocupasse menos o receio da vitória dos patólogos do crime, teria ele compreendido que só o exame a fundo, só uma análise fisiopsicológica completa poderia fornecer ao processo a prova por excelência da incapacidade de adaptação social do criminoso, única base segura e indefectível de um sistema racional de repressão do crime.

Aliás bem instrutivos the deveriam ter sido os exemplos de Kant, Trolong e outros, pois as pretensões invasoras e descabidas de alguns médicos em nada poderiam comprometer a competência particular dos peritos, quando sabia e prudentemente circunscrita aos justos limites das suas legitimas atribuições.

No entanto, a este inconveniente, já muito sério, de se haver, num país como o Brasil, fixado à menoridade limite tão elevado, acrescentam Tobias Barreto e aqueles que entendem que só se pode ser adiantado exagerando as opiniões do mestre, pedidos insistentes para se dilatar ainda mais esse prazo, atendendo a que as nações mais cultas do velho mundo assim o tem feito.

Estranha contradição certamente! Pois, além das razões de nossa acanhada cultura mental, invocam precisamente em favor dessa ideia a diversidade de climas e de raças, que se nota no Brasil. 
Mas nisto vai seguramente desconhecimento completo de dados biológicos fundamentais.

De todas as divergências apontadas, nenhuma neste particular poderá sofrer confronto com a que existe entre as raças que ocupam o nosso território, nenhuma que meça a distancia mental que vai do filho do europeu, do alemão civilizado, à do filho do guarani selvagem, ou quase selvagem ainda.

Pois bem, a observação, confirmando as induções da biologia, demonstra que o desenvolvimento mental é muito mais rápido, a maturidade muito mais precoce nas raças inferiores do que nos povos cultos ou civilizados.

Como todas as crianças das raças inferiores ou atrasadas, escreve o Dr. Letourneau, o menino polinesiano é precoce: porque nas civilizações inferiores, o desenvolvimento prematuro é uma necessidade, o homem não tem lazer para se demorar na infância; mas a inteligência deles é tão limitada quanto pronta em amadurecer. Segundo afirma o Tenente Walpole, os pequenos havaianos educados nas escolas inglesas mostram a princípio uma excelente memória, mas a instrução superior lhes é inacessível. Assim também, os meninos neozelandeses a princípio são mais inteligentes do que os pequenos ingleses, mas raramente são susceptíveis de uma cultura elevada.

O menino negro é precoce, afirma ainda Letourneau; muitas vezes excede ao menino branco da mesma idade; mas cedo seus progressos param: o fruto precoce aborta.

À respeito dos índios brasileiros encontro a sua precocidade nos sérios cuidados da vida, mencionada em mais de um autor.

Notarei, diz o Sr. Couto de Magalhães, que entre os selvagens o menino começa a cuidar da própria subsistência desde os dez anos, sendo contudo auxiliado pelos parentes até que baste a si mesmo.

Dos Chichanás, diz o Sr. Dr. Barboza Rodrigues (Pacificação dos Crichanás, Rio de Janeiro, 1885):

As crianças são transportadas às costas pelas mães, sentadas em uma tipoia, feita do líber da envira (guateria sp.), a cavaleiro sobre os flancos. Os meninos de oito anos em diante usam pequenos arcos e flechas, em tudo semelhantes aos dos homens. Em ambos os sexos nessa idade começam a andar tangados.

Mas entre nós, desnecessários tais exemplos. A precocidade mental é a regra, e infelizmente também a precocidade da sua de cadência muito de perto a acompanha. À um distinto professor isto fez dizer satiricamente que somos um povo de meninos prodígios e homens toupeiras.

A explicação desta diferença entre os povos civilizados e bárbaros é a mesma para todos os autores e reside na herança de uma organização cerebral mais ou menos complexa.

Tem-se observado, escreve Sergi (La Psychologie physiologique, Paris, 1888), que os meninos do Taiti aprendiam tão bem quanto os pequenos ingleses; mas aos doze anos, mais ou menos o desenvolvimento detêm-se no menino taitiano, ao passo que o menino inglês continua a progredir até a idade adulta. Este fato encontra a sua explicação nas condições orgânicas das raças; é que o menino inglês herdou uma organização mais desenvolvida, a da raça inglesa, ao passo que o pequeno taitiano herda uma organização que não teve grande desenvolvimento nos seus antepassados e o seu desenvolvimento pessoal detêm-se por conseguinte nesse estado. Em igualdade de circunstâncias, diz Spencer (Principes de Sociologie), os tipos de organismos menos desenvolvidos não exigem, para chegar à sua forma completa, tanto tempo quanto os tipos mais desenvolvidos; e esta diferença, evidente quando se compara o homem aos animais mais inferiores, encontra-se de novo quando se comparam as diversas raças humanas entre si. Esta diferença deve ser atribuída a uma diferença de desenvolvimento cerebral. Os gastos maiores que exige a formação completa de um cérebro maior, e que retardam por tanto tempo a maturidade do homem em comparação à dos mamíferos em geral, retardam igualmente a maturidade do homem civilizado além da idade em que "se faz a maturidade do selvagem". Sem indagar das suas causas, é certo que, nas mesmas condições, clima e outras, as raças inferiores chegam à puberdade mais cedo do que as superiores.

E com grandes aplicações à nossa tese, acrescenta Spencer:

A terminação do crescimento e da estrutura em um período mais curto nos interessa, porque ela implica a existência de uma natureza menos plástica: a vida no adulto tem uma rigidez e uma imutabilidade que, desde muito cedo, opõem obstáculos às modificações.

É uma lei, diz ainda Spencer (Essais scientifiques), que os organismos gastam tanto mais tempo em se desenvolver quanto mais elevados são: por consequência - deve-se esperar -, as raças inferiores hão de chegar mais cedo ao termo do seu desenvolvimento mental, do que as 
superiores; e é o que temos motivos para acreditar. Viajantes, de volta de todos países, nos faliam ora da extrema precocidade das crianças nos povos selvagens e semicivilizados, ora da idade pouco adiantada em que se detém o progresso mental delas. Esta diferença é geral e temos provas bastantes para que seja inútil um acréscimo.

Não há, portanto, maior contrassenso do que pedir, em nome das nossas raças inferiores e da inferioridade da nossa cultura mental, que nos códigos penais brasileiros se marque a menoridade um prazo maior do que $\mathrm{o}$ aceito para as raças europeias.

Os povos civilizados mais cultos, o inglês, o italiano, o alemão, por exemplo, cujas celebrações devem ser de mais lento desenvolvimento, se contentam com sete, nove, doze anos; no Brasil, por causa das suas raças selvagens e bárbaras, o limite de quatorze anos ainda era pequeno!

Não se confunda o desenvolvimento natural, fisiológico, da inteligência humana, com os efeitos da instrução, cuja influência favorável ou desfavorável sobre a criminalidade é ainda tema de controvérsias.

Tobias Barreto havia afirmado, com efeito, que se a cultura mental da Itália lhe permitia adotar para a menoridade o limite de nove anos, o mesmo não se podia dar no Brasil. Entendia ele que a difusão da instrução, em um país onde ela é obrigatória e onde homens eminentes como Cazali, Cappino, de Sanctis tem sido ministros da instrução publica, autorizava a exigir de um menor de nove anos um desenvolvimento moral maior do que o que se poderia exigir de um menor de quatorze neste vasto país sem gente e dotado de péssimo sistema de ensino.

Mas a esta ilusão responde Garofalo com estatísticas e argumentos esmagadores. Mostra que, ao invés de diminuir, a criminalidade da Itália tem aumentado de um modo ameaçador a partir exatamente de 1860, época de que data a grande difusão da instrução pública naquele país. As estatísticas de d'Haussonville dão o mesmo resultado para a França. Em 1826 em 100 acusados 61 eram iletrados e 39 tinham recebido uma instrução mais ou menos desenvolvida. Atualmente a proporção se acha invertida: 38 iletrados para 70 letrados (na acepção mais modesta do termo). D'Haussonville explica esta inversão nas proporções pelo fato de haver aumentado o número dos letrados sem ter diminuído e até pelo contrário ter aumentado também o número dos crimes, naturalmente resultando apenas daí o aumento do número dos criminosos letrados. E nota ainda o mesmo autor que os departamentos, em que há maior número de acusados, são exatamente aqueles em que a instrução se acha mais disseminada. Garofalo mostra com Tarde que na Espanha onde os iletrados representam dois terços da população, eles só entram por cerca de metade na criminalidade do país. E por fim conclui Garofalo: "Eis aí, pois, como a pobre arma do alfabeto de que se esperava maravilhas é feita em estilhaços pela estatística: a ideia de que "para cada escola que se abre, fecha-se uma prisão" é apenas um absurdo. Seria mesmo supérfluo estar a insistir nisso, porque ainda quando não tivéssemos algarismos em apoio, o simples bom senso nos havia de dizer que não há a menor relação entre a gramática e a moralidade. Pode-se acaso imaginar, por exemplo, que uma paixão qualquer, ou mesmo um prejuízo de honra, possa ser destruído pelo alfabeto?

Poderiam objetar-me, no entanto, que, se a instrução não cria, nem melhora o senso moral, em todo o caso pode apressar o desenvolvimento mental do indivíduo, e influir por aí na maior ou menor precocidade do desenvolvimento psíquico.

Mas ainda assim a objeção seria improcedente. Porque, ou a instrução havia de influir por meio da herança nas gerações seguintes, e, como vimos, Spencer ensina que neste caso o desenvolvimento psíquico é retardado e não acelerado; ou havia de influir em cada menor individualmente, e como neste caso, não só no Brasil, mas em todos os países, a população pode ainda ser dividida em letrados e iletrados, o argumento tirado da situação intelectual da Itália e da Alemanha perderia todo o seu valor e não poderia justificar os limites de nove, doze anos adotados nos seus códigos respectivos.

Mas é fácil reconhecer que a opinião de Tobias Barreto é apenas filha legítima da sua teoria (já suficientemente refutada) da responsabilidade penal, baseada na liberdade da inteligência e não da vontade.

O grau e a cultura da inteligência influem, sem dúvida, decisiva e preponderantemente sobre a fase intelectual da volição, isto é, a ponderação, a comparação, a escolha dos motivos. Uma inteligência mais lúcida e cultivada há de, por certo, julgar e comparar melhor os móveis de ação, apreciar com mais clareza e segurança as suas consequências próximas e remotas, do que uma inteligência acanhada ou sem cultura. Pode-se mesmo conceder mais. Pois que os sentimentos desenvolvem-se paralelamente à perceptividade, o aperfeiçoamento da inteligência e o desenvolvimento da razão tornam-se 
condição de aprimoramento dos sentimentos mais nobres, os sentimentos ego altruísticos ou indivíduo sociais, e particularmente dos sentimentos sociais, ou altruísticos. Assim, pois, o desenvolvimento da inteligência deve auxiliar o desenvolvimento dos sentimentos e concorrer para melhorar o homem.

Mas em que isso pode aproveitar à escola clássica é que eu não sei, nem compreendo.

A capacidade intelectual é uma função de organização cerebral, sobre a qual nada pode a vontade, que por sua vez não é mais do que outra manifestação dessa mesma organização.

A desigualdade na distribuição dos dotes intelectuais - todo mundo o sabe -, é fato totalmente involuntário. Por falta de inteligência nunca foram responsabilizadas as pessoas que são dela destituídas, ou quase destituídas, muito embora estas não possam pretender a estima em que são tidos os homens de inteligência superior.

Se, por conseguinte, apesar de tudo, insiste a escola clássica em distinguir entre menor letrado e menor iletrado, não se compreende que a mesma distinção deixe de existir no adulto entre a responsabilidade do homem inteligente ou instruído e a do homem sem inteligência ou inculto. E quando, como no nosso país, essa desigualdade mental é a consequência da desigualdade antropológica e sociológica das raças que compõem uma população, ela que é orgânica, involuntária e pouco modificável, exige, como já demonstrei, uma atenuação ou diminuição da responsabilidade penal, incompatível com a manutenção da civilização superior que nessa população se queira fazer vingar.

Mas a verdade é que, como demonstrou Garofalo, o crime é principalmente função do senso moral, e o desenvolvimento do senso moral precede o da inteligência, posto que esta possa concorrer para depois esclarecê-lo e aperfeiçoá-lo.

Não tem maior procedência a invocação da influência climatológica, pois que o desenvolvimento orgânico é muito mais rápido e precoce nos climas quentes do que nos climas frios.

Como Ferri, Vito Porto e outros, Alimena louvava o projeto Zanardelli por ter feito descer de vinte e um a dezoito anos o limite da responsabilidade completa na Itália; porque, dizia ele com razão, se países do norte da Europa, como a Alemanha, a Holanda, cantões da Suíça, tem aceitado este e mesmo limites inferiores, não havia motivo para que a Itália, país meridional e portanto mais quente, não o adotasse.

O nosso código penal vigente, inspirado (perdoe-me o legislador), mal copiado do código penal italiano, trouxe-nos, portanto um progresso reduzindo a menoridade de quatorze a nove anos.

Progresso, porque a sociedade habilitou-se por esse modo a reprimir ações antissociais de indivíduos, que, mesmo no ponto de vista do livre arbítrio, já se deviam considerar responsáveis. Mas principalmente progresso, porque, de acordo com os preceitos da teoria positivista dos meios preventivos, ou dos substitutivos penais, quanto mais baixa for a idade em que a ação da justiça, ou melhor do Estado se puder exercer sobre os menores, maiores probabilidades de êxito terá ela, visto como poderá chegar ainda a tempo de impedir a influência deletéria de um meio pernicioso sobre um caráter em via de formação, em época portanto em que a ação deles ainda possa ser dotada de eficácia.

Com certeza os partidários da dilação do prazo da menoridade no Brasil, que são também os partidários do livre arbítrio, não cogitaram na rapidez da maturidade orgânica nas raças inferiores e na absoluta impossibilidade consequente de modificá-las então.

Não há, por conseguinte, maior absurdo do que o nosso código considerar o desenvolvimento no norte do país, situado em zona tórrida e onde predominam o índio, o negro $\mathrm{e}$ os seus mestiços, igual a desenvolvimento mental no sul da república, situado em zona temperada e onde dominam os descendentes dos colonos alemães e italianos.

Neste particular, o projeto do novo código penal, que atualmente se discute no parlamento, nem andou mais avisado, nem se mostrou mais instruído das nossas condições éticas do que os códigos anteriores.

O código de 1830 se havia elevado a menoridade há quatorze anos, tinha em compensação limitado a maioridade criminal aos dezessete. $\mathrm{O}$ de 1890, copiando o código italiano, reduziu, é exato, o limite inferior a nove anos, mas elevou, a certos respeitos pelo menos, o limite máximo a vinte e um.

O projeto elaborado pelo Sr. Dr. João Vieira marca o limite mínimo de dez e o limite máximo de vinte e um anos. Por quê? A não ser pelo 
desejo de tirar a média entre os dois códigos anteriores e escapar assim aos ataques dirigidos contra um e outro código, não sei que se possa invocar para isso razão científica e valiosa.

Respondendo timidamente a Tobias Barreto, escreveu o Dr. João Vieira (Código Criminal Brasileiro, Recife, 1889) que:

se é possível objetar terem a Itália e a Alemanha uma cultura própria da Europa, o que concorre para desenvolver mais depressa o espírito do indivíduo, nós poderíamos responder que a raça e o clima do país concorrem grandemente para o desenvolvimento precoce físico e intelectual.

Não sei, porém, o que sejam a raça e o clima do Brasil. Qual seja o clima do Brasil não nos poderia dizer nem mesmo o ilustrado professor, pois repudiando muito justamente o expediente absurdo de Kitka, mencionado e aceito por Tobias Barreto, escreveu:

Seja como for, o estado a que chegou a ciência atual não permite aceitar neste ponto, como se tem pretendido, que em Estados vastos como o Brasil, que conta regiões as mais diversas, desde o clima ardente sob o equador da Amazônia até o europeu nas províncias do Sul, onde o termômetro desce abaixo de zero, desde as cidades cultas do litoral e das margens dos grandes rios navegáveis até os mais ínvios e inóspitos sertões - se devam fixar em uma lei penal épocas de imputabilidade as mais elevadas possíveis, de modo que, se não abrangerem elas todos os criminosos excluam sempre os inocentes.

Mas se pode-se atender às diferenças de clima com uma legislação penal regional, adversidade de raças, tão intimamente misturadas, em rigor não deveria consentir que se adotasse para a menoridade limites, substituindo-os pelo exame do discernimento. Nisto não haveria grande inovação, porquanto não era mais do que ampliar, estendendo a todos os casos, um exame psicológico, que em certas circunstâncias e para efeitos determinados, já os códigos tornam obrigatório.

Mas o que dissemos do desenvolvimento mental pode-se repetir de cada grande função orgânica das funções sexuais, por exemplo, de que dependem numerosos atos civis e a que se pode referir toda uma série de atentados e crimes.
V. Ora, não parece que valham aqui as razões invocadas a favor da unificação penal na Itália, que triunfou, apesar da falta de uniformidade da sua população, como deixaram demonstrado médicos eminentes e ilustres criminalistas. A situação política do Brasil é exatamente oposta à da Itália, por ventura muito mais fundas e cavadas às distinções étnicas e climatológicas que o dividem em certas zonas ou regiões.

Adotando a federação republicana como forma de governo e condição precípua da conservação da sua unidade política, o Brasil podia bem ter seguido o exemplo da confederação norte-americana, em que cada estado rege-se por um código penal próprio. Não era, pois, a unidade política que lhe impunha a necessidade da unificação penal, como para a Itália admitia o próprio Ferri, conspícuo chefe da nova escola.

Por outro lado, a dualidade da magistratura, como o concebeu e realizou o legislador brasileiro, compreendendo a faculdade de cada Estado adotar a organização judiciária que bem lhe aprouvesse, concedeu, de fato, liberdade maior do que a de possuir um código penal próprio. Aquela Liberdade implica a de adotar o seu código de processo, de fundar e dirigir livremente os seus estabelecimentos penitenciários, isto é, compreende o peão, a condição básica de êxito e de eficácia para qualquer legislação penal.

$\mathrm{Eu}$, disse Tamassia (Il projetto del codice petiale nei suoi rapporti con la giurisprudenza medica), na qualidade de antropologista que considera a criminalidade um fenômeno fatal da vida social e que não tolera a ditadura do convencionalismo político, preferiria que, em vez de um código penal único se tivesse pensado antes no código do processo penal, retocando especialmente a instituição dos jurados.

Mas, o código penal não basta, diz por sua vez um entusiasta do projeto Zanardelli. É indispensável um tribunal de cassação único, a fim de colocar a Itália na altura das outras nações civilizadas. É indispensável uma reforma do processo, sem a qual as leis permanecerão platônicas, uma reforma que cuide de uma indenização séria e pronta dia parte lesada. É indispensável colocar os juízes na altura da ciência moderna e para isso seria indispensável separar a magistratura civil da magistratura penal; teríamos assim especialistas.

Ora, a organização judiciária da Bahia, já promulgada, nos poderá dar a medida da latitude de atribuições que confere aos estados essa concepção de um código penal único com magistratura dupla. 
Creio bem que a organização judiciária da Bahia seja excelente. Em todo caso falta-me competência para analisá-la. Mas sei que nada buscou atender às exigências e ensinamentos dessa poderosa corrente de reformas judiciárias a cuja benéfica influência procuraram, ou pelo menos desejaram atender os próprios legisladores do código italiano pelo qual pretendeu a União Brasileira modelar a sua legislação penal.

VI. Em matéria de júri, a situação agravou-se em vez de melhorar; substituí-lo foi em que não se pensou.

$\mathrm{O}$ art. 113 da lei da organização judiciária estadual (n. 15 de 15 de Julho de 1892) parece ter sido escrito de propósito para justificar a seguinte afirmação de Tarde:

O primeiro encontrado, qualquer que seja a sua profissão e contando de moralidade não esteja muito abaixo da media, pode ser jurado; que, por acaso, é suspeito de alguma competência judiciária, apressam-se a recusá-lo. O seu mérito está na sua incompetência.

Reza o art. 113:

§ 1. Não serão inscritos na lista dos jurados: o chefe do poder executivo, os arcebispos, bispos e clérigos de ordens sacras, os pastores de seitas protestantes, comandantes militares dos corpos de linha, do regimento policial ou de outra força, em serviço ativo, oficiais da armada em efetivo exercício a bordo, os chefes de repartições publicas, magistrados, preparadores, membros do ministério publico, secretários do governo e dos tribunais, escrivães judiciais ou de polícia, os tabeliães ou oficiais de justiça.

$\S 2 .^{\circ}$ Serão inscritos, mas não obrigados a servir: os senadores e deputados federais ou do estado, os advogados, professores públicos, e os empregados públicos, quando sua dispensa for requisitada pelos respectivos chefes.

Num país onde o funcionalismo público absorve quase todo o pessoal que possui certa dose de conhecimentos, onde a instrução publica está ainda tão pouco disseminada e em que tão grande é a repugnância a servir nos júris, esse artigo pode se gabar de ter conseguido retirar de todo destes tribunais, já não direi os de maior competência judiciária, porém apenas os menos incapazes, analfabetos e independentes. Quem conhece o nosso país, está plenamente habilitado a julgar agora o que há de ser o júri fora das cidades, nas comarcas do interior.
VI. Em matéria de especialização da magistratura criminal, se tivesse a mente deliberada de contrariá-la em toda linha, não era possível fazer mais do que ficou estabelecido na organização dos tribunais e juízos deste Estado.

Toda essa critica severa e implacável a que os Ferri, Garofalo, Tarde e tantos outros submeteram o enciclopedismo da magistratura europeia, ficou letra morta para o legislador brasileiro, que pretendeu talvez bem poder a nossa privilegiada superioridade mental desprezar esse dilema formulado por Tarde.

Agora ou nunca é ocasião de aplicar esse famoso princípio da divisão do trabalho, que a economia política, com tanto exagero, é verdade, preconiza em sua esfera. Separemos inteiramente, pois, as duas magistraturas, uma criminal e a outra cível: especializemos e localizemos cada uma delas em sua missão própria.

O que é a perícia científica, o que vale a organização médicojudiciário no Brasil, já eu o disse em um trabalho publicado no Brasil Médico ( $O$ exercício da medicina pública): como está, ela é o compromisso dos créditos científicos da medicina brasileira, é a ameaça constante à liberdade e à honra do cidadão. Demonstrei-o então com alguns exemplos; já os possuo em maior copia para em breve voltar de novo ao assunto.

VII. A análise dos estabelecimentos penitenciários deste estado nos leva às mesmas conclusões. Aqui basta transcrever documentos oficiais. $\mathrm{O}$ Dr. António Pedro de Mello (Mensagem do Governador à Assembleia Legislativa, Bahia, 1894), encarregado de proceder um exame na casa de prisão com trabalho, assim se pronuncia sobre ela:

O regime da casa de prisão com trabalho não está de acordo com as exigências da penal o que a moderna e não satisfaz as condições exigidas pelo novo código penal. Não exagero dizendo que nem ao menos esse estabelecimento tem se conservado estacionário, pois, provarei que há ali alguma coisa em que, pior do que isso, ele tem retrogradado... Até agora não se cuidou do que, nos estudos penitenciários, tem a denominação de instituições complementares, às quais dever ser consideradas dependências desse estabelecimento, o que torna inúteis os artigos do código que faliam em penitenciárias agrícolas, estabelecimentos industriais, etc. (Arts. 48, 49, 50, 53 e 54 do código.). Nem se diga que o que venho de dizer seja um sonho de mais um espírito amante de utopias; porquanto não sou eu, não é a ciência penal, não é a observação e a experiência, não é nada disto 
somente; é mais o nosso atual código penal que está a dizer que a nossa penitenciária não pode continuar a ser o que tem sido até hoje, sob pena de inobservância de muito do que ele preceitua.

Ainda bem: a constituição federal entendeu que a importância dos sistemas penitenciários consentia que se fizesse aos estados a concessão de se ocupar delas, pois que, tolhida como estava aos estados à faculdade de possuir cada qual a sua legislação penal própria, todos os males possíveis haviam sido prevenidos. Eis, no entanto, que a penitenciária da Bahia, um dos mais importantes estados da União, torna o código federal um luxo inútil, uma criação altamente teórica e sem utilidade prática, e mais do que tudo isto, uma escola perigosa de criminosos temíveis.

O código do império estatuía que só menores, que houvessem cometido crimes, obrando com discernimento, seriam recolhidos à casa de correção. $\mathrm{O}$ novo código, à semelhança do italiano, manda recolhe-los a estabelecimentos agrícolas especiais (art. 31). Tais estabelecimentos não existem, porém, e os menores continuam a ser recolhidos à penitenciária e à casa de correção. As observações seguintes, que colhi na penitenciária, referidas mesmo resumidamente, não testemunho eloquentíssimo dos efeitos dessa medida.

A. O menor José d'Araujo, de Santo Antonio das Queimadas, recolhido à casa de correção até completar dezessete anos (artigo 13 do código penal do império), por haver, na idade de nove para dez anos, assassinado o próprio pai, obrando com discernimento.

Há mais de quatro anos conheço este criminoso e tem sido sempre a mesma narração do seu crime, feita, aliás, sem revelar o menor sentimento de pesar. A mandado de um inimigo do pai, o qual the deu de recompensa uma moeda de quarenta réis, resolveu cometer o parricídio.

O pai estava ausente. Na noite do crime, deitou-se o menor, como de costume, numa mesma cama com os irmãos e adormeceu. Acordando alta noite, viu o pai que era chegado e dormia em uma rede no mesmo aposento da choupana que habitavam. Levantou-se então, foi a um canto, onde se achavam as armas de caça, tomou uma velha espingarda de pedra que sabia carregada, foi buscar um tição acesso e com ele fez disparar a arma, matando instantaneamente o pai, que foi ferido na cabeça.

Esta é a história que ele tem sempre referido, e sabida de todos na penitenciária. Interrogando-o convenientemente, verifiquei que ele não havia dado desde começo esta informação às autoridades, e só acusou de mandante ao inimigo do pai dois meses depois de preso. Da guia que o acompanhou à penitenciária consta que não ficou provada a existência de um cúmplice, não havendo provas contra o acusado. Não pude consultar o processo.

Este menino, que já era órfão de mãe, morta de parto, vivia com mais cinco irmãos em companhia do pai que, sendo pobre, com eles se ocupava na pequena lavoura de que subsistiam. Nem ele, nem os irmãos, haviam recebido instrução de espécie alguma.

Transferido para esta cidade, foi colocado na penitenciária para aprender o ofício de sapateiro. $\mathrm{O}$ tratamento moral que devia receber naquele meio já produziu todos os seus efeitos naturais e lógicos, e a obra está completa. $\mathrm{O}$ criminoso tem dezoito anos, é ladrão, pederasta passivo, jogador, bêbado, um ser completamente desmoralizado, enfim, um incorrigível temível.

Há pouco tempo, servindo-se de chaves falsas, roubou matéria prima de arrecadação, a mandado de terceiro protesta ele. A administração está informada de que esteve amasiado com um companheiro como pederasta passivo durante dois meses. Por infrações disciplinares de toda a sorte, jogo, embriaguez vive constantemente em castigo. O administrador afirma que não sabe mais o que há de fazer ele.

Resolvi-me a completar o estudo deste criminoso. É um pardo em que os caracteres do mulato e do mameluco estão bem combinados. Ainda completamente imberbe, apenas ligeiro buço. Não apresenta deformação ou estigma físico, não é canhoto, nem ambidestro. As medidas cefálicas tomadas dão os seguintes resultados.

\begin{tabular}{|l|l|}
\hline Diâmetro anteroposterior máximo & 180 \\
Diâmetros transverso máximo & 155 \\
Diâmetro frontal mínimo & 110 \\
Diâmetro frontal máximo & 150 \\
Altura nasal & 52 \\
Largura nasal & 42 \\
\hline
\end{tabular}

Donde calculamos um índice cefálico hiperchachycéfalo de 86,11 e um índice nasal de 80,76. 
A fisionomia do criminoso é sem expressão, tem aparentemente um ar de submissão que parece convencional; de fato é ele impassível, referindo o crime em todas as suas minudências como se tratasse da coisa mais natural do mundo. Todavia nem faz garbo do crime, nem revela logo à primeira vista o cinismo do menor que fará objeto da observação seguinte. Porque parte entra nesta conduta a perversidade congênita e o lapidamento da prisão, é o que não posso dizer. Embora com dificuldade, consegui hipnotizar o criminoso e desde então procurei indagar que influência podiam ter exercido no seu espírito a suposta ordem do inimigo do pai e a do companheiro quem imputa a sugestão do roubo. Hipnotizado, revelou o criminoso que tal ordem nunca havia existido e que o verdadeiro motivo do crime havia sido a circunstância de ter ele, na ausência do pai, cortado um pé de mandioca e prometido um tio que assim que o pai chegasse lhe havia de comunicar o fato para que ele castigasse o filho. Foi, pois, para evitar o castigo que este cometeu o parricídio.

Daí em diante, mesmo em vigília, o menor passou a contar-me o fato por este modo, confessando que tinha sido falsa a invenção de um mandante. Também por este meio consegui a confissão completa dos seus hábitos pederastas que até então ele teimava em negar.

Nada indica que este rapaz tenha sido vítima de sugestões estranhas na prática dos seus crimes. Continuo a estudá-lo, mas não é de difícil hipnotização e opõe obstáculos às sugestões, aparentando aceitá-las, mas sendo realmente muito dissimulado.

Trata-se neste caso de um criminoso nato, ou de criminoso de hábito aperfeiçoado pelo meio? Esta última classificação tem em seu favor a falta dos grandes estigmas físicos do criminoso nato. Mas a precocidade deste criminoso, a natureza do seu crime em que se revela uma ausência completa do sentimento de piedade, ou pelo menos de simpatia para com o seu progenitor, a futilidade do movei, pois que para evitar um castigo, qualquer criança normal teria fugido ou procurado apadrinhar-se, a invenção mentirosa de um mandante, atribuindo o crime a um indivíduo que sabia inimigo de seu pai, a insensibilidade moral, a indiferença que revela em todos os seus atos, tudo enfim me faz crer que se trata de um grande criminoso da classe dos criminosos natos.

B. Ignácio José da Silva, condenado pelo júri de Brotas de Macahubas a oito anos de prisão com trabalho por ter assassinado um menino em 1889.
Diz este menor que tinha por ocasião do crime onze para doze anos, mas que, para poder condená-lo, o júri atribuiu-lhe quinze anos. Não pude examinar o processo, mas da guia que o acompanhou à penitenciária consta realmente que ele tinha doze anos e a julgar pela aparência não podia ter mais.

Pouco valor pode ter para nós a narração do crime feita apenas pelo menor, que pretexta como causa uma luta entre um irmão e a vítima. Mas o exame atual é bastante instrutivo.

É filho natural e tem cinco irmãos. A mãe havia abandonado o pai, que depois disso casou com outra mulher. Ele e os irmãos moravam com a avó materna, mas eram sustentados pelo pai. Ocupavam-se na lavoura e, como os irmãos não tinham instrução alguma, apesar de haver escola primaria na localidade.

É mulato claro, com uma conformação craniana facial assimétrica, hyperbrachycephalo com um índice cefálico de 88,13 , as orelhas muito destacadas do crânio e mal conformadas, a abobada palatina profundamente escavada, gago em extremo.

É de um cinismo a toda prova; fala dos seus crimes rindo-se e comentando-os com pretensões a espirituoso.

Também é pederasta passivo, ladrão, jogador e bêbado. As medidas cefálicas dão as seguintes indicações:

\begin{tabular}{|l|c|}
\hline Diâmetro anterior, posterior, máximo & 177 \\
Diâmetro transverso & 156 \\
Diâmetro frontal mínimo & 105 \\
Diâmetro máximo & 125 \\
Altura do nariz & 42 \\
Largura do nariz & 40 \\
Diâmetro bizigomático & 135 \\
Altura da face (do queixo à inserção dos cabelos) & 165 \\
Circunferência ofrioinaca & 360 \\
Transversa biauricular & 370 \\
Arco do ófrio ao couro cabeludo & 45 \\
Ófriobregmatico & 140 \\
Parietal (bregma ao lambda) & 110 \\
\hline
\end{tabular}


Este menor, apesar de muito claro, tem caracteres inferiores muito acentuados. Um índice cefálico hyperbrachycephalo $(88,13)$, um índice nasal muito platirrino (105), um arco parietal muito fraco, etc.

C. José Joaquim Caetano, de dezoito anos, está na penitenciária desde a idade de quatorze anos, por haver assassinado uma mulher que o queria castigar. Mulato escuro e filho natural de escravos, este menor é considerado na penitenciária como o mais bem comportado dos seus companheiros de idade: aprendeu a arte de sapateiro e tem habilidade.

Viciado pelo meio, também é jogador e já se tem embriagado, mas não é ladrão e dizem-no sensível aos castigos.

Atendendo à sua origem, de pais escravos e negros ou mulatos escuros, atendendo aos vícios inerentes à sua condição de escravizado, é possível que este menor seja antes um criminoso de ocasião do que um criminoso nato.

De acordo com a escola italiana que pregou sempre a importância do fato individual ou biológico na gênese do criminoso, farei notar que, apesar da igualdade das condições de meio em que se acham colocados estes menores, a influência se faz sentir menos neste do que nos seus companheiros. O administrador, como os diretores da oficina em que trabalha, são acordes em considerá-lo melhor do que os outros.

D. Dois menores existem mais na penitenciária, um criminoso de ferimentos graves e outro lá colocado como vagabundo. Esses não oferecem o interesse dos precedentes, mas estão ambos em via bem adiantada de aperfeiçoamento na carreira do crime e da degradação.

VII. Eu não pretendo seguramente que cada estado brasileiro deva ter o seu código penal à parte. Nem há necessidade disso. Queria que, desde que se lhes concede que tenham organização judiciária própria, fossem igualmente habilitados a possuir a codificação criminal que mais de acordo estivesse com as suas condições étnicas e climatológicas. Nestas condições, diversos estados, os mais afins, poderiam adotar o mesmo código e as diferenças se fariam sentir apenas naqueles em que a divergência das condições mesológicas fosse mais acentuada. Se em rigor o Pará e o Amazonas se podem reger pelo mesmo código penal, é intuitivo, no entanto, que esse código não deve servir à Bahia e muito menos ao Rio Grande do Sul.
Eu sei bem que a tendência moderna é a unificar os códigos, que a Itália já o fez, que a Suíça está em via de fazê-lo, e que mesmo na América do Norte essa ideia tem partidários. Mas tudo isso prova apenas um fato que ninguém contesta o domínio, a influência diretora da escola clássica.

Para demonstrá-lo, se não bastava o código italiano, está agora aí o anteprojeto do código penal suíço, redigido por Stooss e que acaba de ser apresentado ao Conselho Federal. Entre outras inovações da escola clássica lá vem consignada a responsabilidade atenuada, isto é, a porta aberta para a impunidade ou semi-impunidade geral.

Se ao menos a unificação dos códigos tivesse, como afirma Alimena, a vantagem de unificar as populações, eu não duvido que a ideia pudesse ser advogada com vantagem.

Ao lado da adaptação natural, disse ele, se acha a adaptação artificial $\mathrm{O}$ legislador pode e deve unir a população, para isto tem ele muitos meios dos quais, talvez, os dois principais sejam o ensino da mesma língua (é por isso que os vencedores sempre impõem a sua língua aos vencidos) e a mesma legislação.

Mas realmente esta pretensão não tem o menor fundamento. A menos que não se suponha e admita que os códigos podem modificar os climas, e com os climas as condições de adaptação dos grupos humanos, a menos que não se creia que os códigos possam modificar as raças, independente das adaptações mesológicas, eu não sei como se há de pretender que a imposição do código penal inglês à Índia, para me servir de um exemplo de Alimena, possa converter os índios em ingleses, e o clima da Índia no clima da Inglaterra.

Depois, para o Brasil a objeção de Alimena tem pouco valor, porque ele admite que, se as condições de clima e de topografia não justificam a adoção de legislações diversas entre a Lombardia e Roma, entre Roma e Nápoles, em todo caso elas o justificam entre a Noruega e a França, entre a Rússia e a Grécia, etc. Ora, a diferença entre a Noruega e a França será maior do que a que existe entre o Rio Grande do Sul e Pará? Não o creio.

Mas ainda quando esse efeito fosse verdadeiro e possível, ainda quando se deva atender a ele nos casos de populações quase homogêneas como a da Itália onde a unificação da legislação pode ter essa consequência, é intuitivo que a primeira condição para isso será abandonar o critério da uniformidade do livre arbítrio nas diversas raças, formalmente desmentido 
pela biologia, e substituir por meios educadores, a estúpida panaceia da prisão celular, essa aberração do século XIX, no justo dizer de Enrico Ferri.

Esse resultado só o poderia alcançar um sistema racional de penalidade qual o que instituiu e propõe a escola positiva.

Para povos heterogêneos e novos, como o brasileiro, ele não é somente o mais adapta do, é ainda facilmente adaptável. E seria um erro perder a oportunidade de dar-lhe realização.

Não temos, como os povos que possuem uma velha civilização, o grande obstáculo das tradições e dos usos inveterados. Há, por isso, entre nós extrema facilidade na adoção de todas as novidades, porque, povo novo como somos, todas as instituições são novas para nós e só temos a dificuldades da escolha.

Se de algum exemplo se houvesse mister, aqui, nenhum teria o valor da facilidade com que se retocam, se renovam os códigos no Brasil, sem protesto, sem defesa, sem luta em fim.

O projeto do novo código penal que altera tão profundamente a legislação criminal vigente, passou em segundo discussão na câmara, sem provocar o menor reparo. E, fora da câmara, quer na imprensa médica quer na imprensa jurídica, não me consta que tenha provocado um só artigo. Onde os defensores da escola clássica?

Parece que no Brasil não se faz sentir sequer essa luta titânica que se trava a esta hora nos domínios do direito criminal e em que as ciência positivas tentam nada menos do que o assalto definitivo ao último reduto da metafísica - o domínio pratico das instituições jurídicas.

O fato não é novo, nem é desconhecido.

Comparando a luta porfiada, os combates tenazes que se travam no velho continente para fazer vingar as novas ideias científicas nos domínios da higiene prática, com a facilidade com que essa ideias são postas em execução no novo mundo, exclamava um distinto escritor:

Felizes os povos que não tem passado científico! Eles não tem que lutar com a tradição, com a rotina, não tem que destruir resultados materiais adquiridos, prejuízos enraigados!
Para aplicar as novas invenções e consagrar as teorias científicas modernas, os governos não vão de encontro a hábitos seculares, a interesses coalisados, ao espírito de rotina, a oposições sistemáticas. Observado já na Rússia este fato recebe nova confirmação no Chile: e a coincidência é tanto mais absoluta quanto um desses países é o governo mais absoluto e que o outro ao contrário é uma república onde o presidente nada pode empreender sem o assentimento dos representantes do país.

Oxalá a consciência exata da superioridade que nos assiste neste particular, possa guiar o legislador brasileiro na confecção da nossa legislação criminal, da qual não se possa vir a dizer nunca que mesmo para o seu tempo já era ruim e atrasada. 